Technical Report: N-TRT-F-00001

Revision 0

\title{
Applicability of International and DOE Target Values to ALD Destructive Measurement Applications (U)
}

Author: M. K. Holland

Technical Agency: Analytical Laboratories Department (ALD)

October 17, 2002

\section{UNCLASSIFIED}

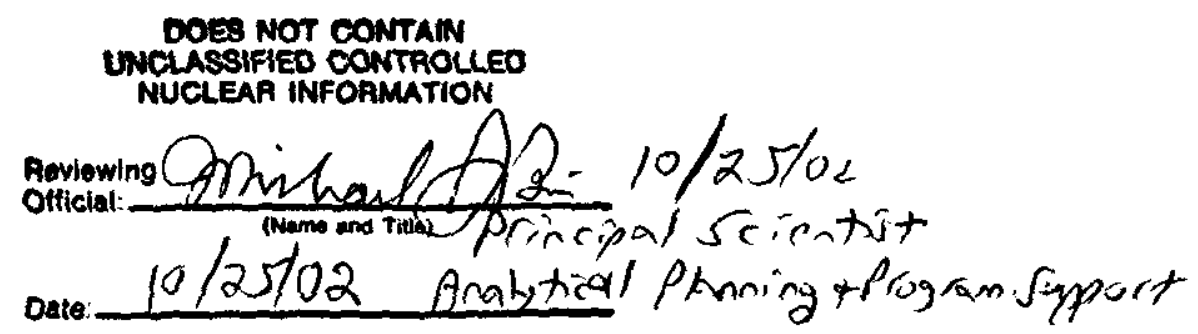


This document was prepared in conjunction with work accomplished under Contract No. DE-AC09-96SR18500 with the U. S. Department of Energy.

\section{DISCLAIMER}

This report was prepared as an account of work sponsored by an agency of the United States Government. Neither the United States Government nor any agency thereof, nor any of their employees, makes any warranty, express or implied, or assumes any legal liability or responsibility for the accuracy, completeness, or usefulness of any information, apparatus, product or process disclosed, or represents that its use would not infringe privately owned rights. Reference herein to any specific commercial product, process or service by trade name, trademark, manufacturer, or otherwise does not necessarily constitute or imply its endorsement, recommendation, or favoring by the United States Government or any agency thereof. The views and opinions of authors expressed herein do not necessarily state or reflect those of the United States Government or any agency thereof.

This report has been reproduced directly from the best available copy.

Available for sale to the public, in paper, from: U.S. Department of Commerce, National Technical Information Service, 5285 Port Royal Road, Springfield, VA 22161, phone: (800) 553-6847, fax: (703) 605-6900

email: orders@ntis.fedworld.gov

online ordering: http://www.ntis.gov/help/index.asp

Available electronically at http://www.osti.gov/bridge

Available for a processing fee to U.S. Department of Energy and its contractors, in paper, from: U.S. Department of Energy, Office of Scientific and Technical Information, P.O. Box 62, Oak Ridge, TN 37831-0062,

phone: (865)576-8401,

fax: (865)576-5728

email: $\underline{\text { reports@ adonis.osti.gov }}$ 
Applicability of International and DOE Target Values to ALD Destructive Measurement Applications (U)

\section{Review and Approval - Signatures / Dates}

Author

Michael K. Holland

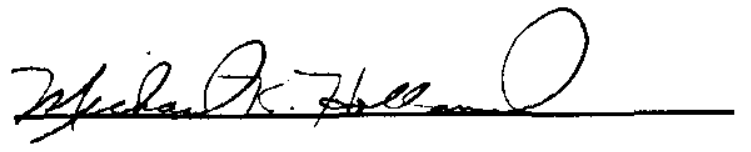

03-October-2002

Technical Reviewers:

Kimberly N. Carter

Christopher J. Hennigan

Sherold R. Johnson

Patterson R. Nuessle

James Satkowski

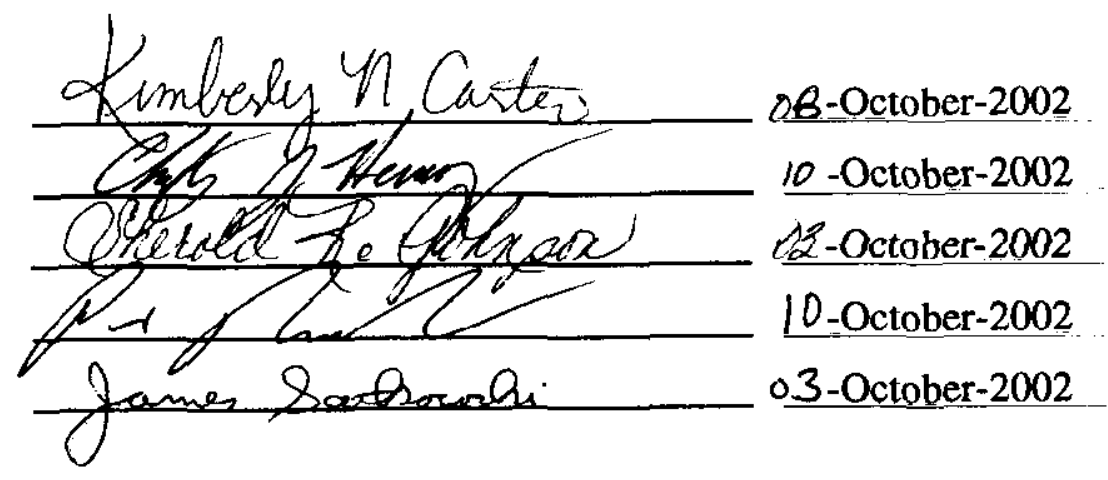

Management Approvers:

Robin H. Young

Woodie L. Melton, III

Scott E. Federman

Patricia C. Padezanin

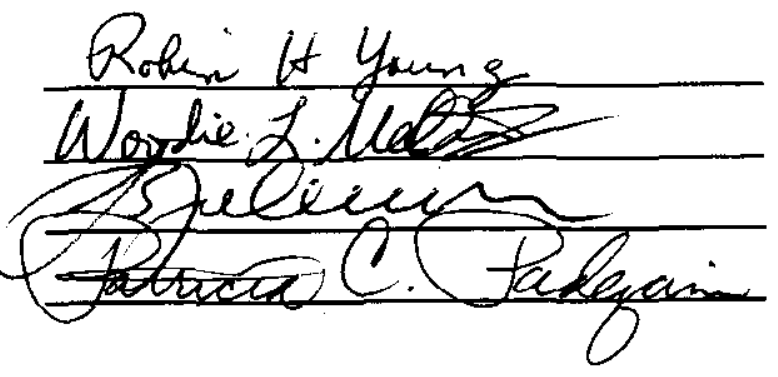

16-October-2002 10_-October-2002 11 -October-2002 17-October-2002 


\section{Key Words}

Accountability, Safeguards, International Target Values, Runs Rule, Measurements, Reliability

\section{Abbreviations}

\begin{tabular}{|c|c|}
\hline ALD & Analytical Laboratories Department \\
\hline CLAS & Central Laboratory Analytical Services \\
\hline CTF & Cognizant Technical Function (scientist over a measurement system) \\
\hline DA & Destructive Analysis \\
\hline ESARDA & European Safeguards Research and Development Association \\
\hline ESARDA/WGDA & Working Group on Techniques and Standards for Destructive Analysis \\
\hline GQ & $\begin{array}{l}\text { Goal Quantity - Significant quantity of fissile material safeguarded to prevent } \\
\text { diversion and subsequent assembly of a thermal nuclear device. }\end{array}$ \\
\hline HEU & High Enriched Uranium \\
\hline IDMS & Isotope Dilution Mass Spectrometry \\
\hline IAEA & International Atomic Energy Agency \\
\hline ISO & International Standards Organization \\
\hline ITV & International Target Value(s) \\
\hline LEID & Limit of Error on Inventory Differences \\
\hline LEU & Low Enriched Uranium [ $5 \%{ }^{235} \mathrm{U}$ from SRS HEU Blenddown] \\
\hline LLNL & NNSA Nuclear Site - Lawrence Livermore National Laboratory \\
\hline LANL & NNSA Nuclear Site - Los Alamos National Laboratory \\
\hline NBL & New Brunswick Laboratory [DOE-CH, Argonne, IL] \\
\hline MBA & Material Balance Area \\
\hline MC\&A & Material Control, and Accountability \\
\hline MPC\&A & Material Protection, Control, and Accountability \\
\hline NMMD & Nuclear Materials Management Division \\
\hline NUS & Nuclear Fuel Services, Erwin Tennessee \\
\hline QC & Quality Control \\
\hline PUREX & Plutonium and Uranium Extraction Process (previously used in F-Canyon) \\
\hline Pu ISO & An analysis for Pu Isotopic Distribution (\%) by TIMS \\
\hline TIMS & Thermal Ionization Mass Spectrometer \\
\hline U ISO & An analysis for U Isotopic Distribution (\%) by TIMS \\
\hline Y-12 & NNSA Nuclear Site - Y-12 Plant in Oak Ridge, Tennessee \\
\hline
\end{tabular}




\title{
Purpose
}

To document Analytical Laboratories Department's (ALD's) technical assessment of compliance requirements and applicability of the International Target Values (ITV) and Central Laboratory Analytical Services' (CLAS's) implementation status. This report also discusses the additional DOE guidance/requirements related to target values.

\begin{abstract}
International Target values and target value applicability are a function of the nuclear material processing campaign or application for which the accountability measurement method is being applied. Safeguarding significant quantities of nuclear-grade materials requires that accountability measurements be as accurate, precise, and representative as practically possible. In general, the ITV provides a benchmark for determining generic acceptability of the performance of the various accountability measurement methods, since it represents a performance level that is accepted as highly reliable. There are cases where it is acceptable to select alternative accountability methods not specifically referenced by the ITV, or to use the recognized measurement method, even though the uncertainties are greater than the target values.
\end{abstract}

These cases include:

- When the material homogeneity or stability is not consistent with the basic assumption associated with application of the ITV;

- When the total quantity of material being protected is small, and thus the total uncertainty associated with the accountability measurement meets the safeguard objective for this material;

- When the measurement uncertainty is not significant relative to other nuclear material accounting uncertainties; and

- When analytical method selection is driven by the need to avoid potential interferences that are (or are sometimes) expected to be present.

It may also be necessary for the laboratory, the customer, and the accountability oversight organizations to accept more liberal method uncertainties than those recommended by ITV because:

- The laboratory is not staffed and funded to achieve the ITV; and/or

- The turnaround time requirements dictate method selection and methodology, not the ITV.

This report discusses the status and applicability of accountability measurement methods performed by Central Laboratory Analytical Services (CLAS), relative to ITV values, and to DOE's endorsement of these ITV as benchmarks.

This report provides additional information related to the CLAS implementation of the "Runs Rule" and the relationship of its technical basis to the International Target Values. 


\section{Assumptions}

Major steps ${ }^{1}$ in accountancy verification measurements that need to be addressed, known, and validated to ensure the entire measurements process is effective are:

1. Bulk measurements - volume or mass of material

2. Sampling - A representative portion of material is taken from the bulk material.

3. Sample conditioning - Precautions taken to ensure the measured characteristics are preserved during packaging and transport.

4. Shipment - Transport of the sample and chain-of-custody

5. Sample Validation

6. Laboratory takes representative subsample / aliquot.

7. Sample Treatment - Bringing the sample into the most appropriate geometrical, physical, and/or chemical form in preparation for measurements.

8. Measurement - Analytical determination of desired sample characteristic.

9. Calculations - Transforming all results of the measurement into the desired estimate.

10. Reporting Results - Prevent clerical errors during report generation and ensuring proper control of the record to allow retrieval consistent with QA plans. 


\section{Introduction}

The European Safeguards Research and Development Association's Working Group on Techniques and Standards for Destructive Analysis (ESARDA/WGDA) developed the first set of International Target Values. The WGDA's membership included the international commercial nuclear fuel industry and members of International Atomic Energy Agency (IAEA). Their goal in developing the first set of International Target Values was to provide aggressive benchmarks for key accountability and international safeguard measurements performed in commercial nuclear fuel reprocessing.

These ITV were designed to protect goal quantities (GQ) of nuclear-grade materials at various stages in the reprocessing flowsheet, with consideration given to the state-of-the-art, state-of-thepractices, and the technical limitations for the various measurement methods as well as the attractiveness of the type of nuclear material. In general, it is assumed that the nuclear fuel reprocessing organization has invested adequate time, planning, design, funding, and staffing to provide near ideal / state-of-the-art conditions for sampling and measurements (and bulk material measurements). DOE endorses these target values as benchmarks for assessing measurement performance when applied to appropriate nuclear materials and key accountability/safeguard applications.

The "International Target Values" for nuclear material accountability were developed with a clear scope of applicability and basis for their calculation. Large-scale commercial reprocessing activities have the potential for diversion of special nuclear materials into covert weapons programs. The ITV are intended to provide plant operators, laboratories, and safeguards regulators with a benchmark for achievable measurement quality, under well controlled conditions that were considered routine for the European reprocessing facilities and their analytical laboratories.

Isotope Dilution Mass Spectrometry (IDMS) is the method of choice for input accountability measurements for spent fuel dissolver solutions. Measurement of a dissolver solution required optimum accuracy and precision due to the large quantity of nuclear material that was protected by a single measurement. Measurement uncertainty requirements driven by the accountability objectives for dissolver solution presented challenging target values for mass spectrometry when applied to commercial dissolver solutions. Implicit with these target values was the need and capability to obtain and provide for measurement, samples that are representative (with a sampling uncertainty significantly below the measurement target values for precision and accuracy). Sampling uncertainty could be bounded by measurement uncertainty for this type of application because the physical form of the material (solution) and the availability of reliable sample equipment permitted this quality of sampling. In addition, the ability to correlate between measurements, $(\mathrm{Pu}, \mathrm{U}$, Density) and validate results of replicate sample measurements and different measurements $(\mathrm{Pu}, \mathrm{U}$, Density) aided in ensuring a reliable sampling process.

The requirements for accurate volume measurement of the bulk material supported the assignment of the challenging measurement target values. ITV's that are significantly less than the uncertainty associated with the bulk material measurement are not consistent with the intent of the ITV and are not cost effective. 


\section{Evaluation/Discussion}

Clearly, stringent/challenging measurement target values are not appropriate or cost effective if large uncertainties exist in the bulk material measurement and/or the sampling process. If the material being sampled is not homogeneous, then the sample process will have larger than ideal random and systematic error components, which are likely to dwarf the International Target Values for measurements. When measurement target values are dwarfed by other sources of accountability error, the ITV's should not be treated as applicable goals for measurement uncertainty in that specific nuclear material processing activity.

Analytical measurement methods that meet or exceed the requirements of the International Target Values for precision and accuracy are accepted as generically appropriate to nuclear material accountability application. DOE should (and does) endorse the International Target Values as a benchmark for assessing measurement quality. When applied to sample types that are within the scope and technical capability of the measurement method, methods that meet the International Target Values automatically have the necessary pedigree for nuclear material accountability.

However, the converse is not true. Measurement methods that have random and systematic error components that exceed the target values do not automatically fail to meet requirements for all accountability applications. The nuclear material processing activities must be evaluated to determine the impact of measurement uncertainty on potential inventory differences. Attention must also be given to all sources of uncertainty including bulk material measurement, representative sampling, material homogeneity, and material stability. The assessment of impact on inventory differences must ensure that these sources of error receive the same challenging level of scrutiny that is more easily and quantitatively applied to destructive measurement methods.

Each of these sources of uncertainty has random and systematic error components. Because of the implied applicability of the International Target Values, appropriate International Target Values for each of these error sources do not exist for all potential applications.

For example, commercial nuclear-grade plutonium and uranium nitrate solutions and oxide materials have product specifications and manufacturing conditions that ensure homogeneity. However, these specifications are not applicable to scrap oxide materials. By their nature, scrap materials have varying degrees of nonhomogeneity and stability. Thus a sampling process may obtain a "representative sample," but samples collected by this process can still have significant random and systematic errors relative to the bulk material. An appropriate target value for sampling these types of materials may be 5-20\%, dictated primarily by the homogeneity of the material (not by the limits on the potential inventory differences derived by calculations that are based on goal quantities). For the sampling of 'dirty scrap' materials, the International Target Value 2000 provides a random error target value of $10 \%$ for scrap materials, but lists the target value for systematic error as 'not yet defined.' This situation acknowledges the difficulty associated with defining target value requirements for the sampling of scrap and scrap-like nuclear materials, such as the FB-Line and HB-Line processing of mixed scrap materials. 


\section{Evaluation/Discussion, continued}

A copy of the "Destructive Assay Methods Compendium"2 developed by a team composed of representatives from DOE-New Brunswick Laboratory, LLNL, LANL, Y-12, and SRS is attached for information. This document was prepared as an aid to the Joint U.S. - Russia MPC\&A Program. Standard Organization-11 is planning to publish this document as an ISO Technical Standard. It expands upon the International Target Values, providing aggressive goals for measurement reliability, while still considering the significant differences between measurements of pure-type materials and scrap materials. Consideration is given to the technical capability of the various measurement methods that can be appropriately used for different types of nuclear material accountability applications. This document also contains some programmatic guidance for calculating appropriate material balance area (MBA) inventory difference limits to estimate uncertainty requirements for destructive assay measurements.

The target value tables within the DA Method Compendium consistently endorse the International Target Value for the material types to which they apply and provide more appropriate measurement target values for materials of lower quality (and lower significance to the safeguards program objectives). Examples where the DA Method Compendium provides more appropriate target values for measuring scrap and waste materials include:

$\mathrm{Pu}$ Coulometry

U Titration

$\mathrm{Pu}$ Titration

$\mathrm{U} \& \mathrm{Pu}$ Fluorescence

Pu Spectrophotometry

U \& Pu IDMS

\section{Random Error (1-sigma)}

\section{$1.0 \%$}

$0.5 \%$

$1.0 \%$

$3.0 \%$

$1.0 \%-2.0 \%$

$0.5 \%$

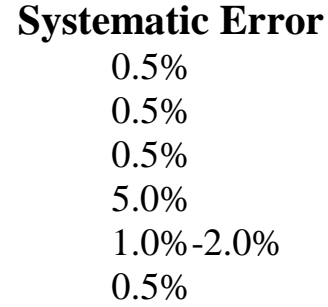

Systematic Error

$0.5 \%$

$0.5 \%$

$1.0 \%-2.0 \%$

$0.5 \%$

Each of these target values presumes that the measurement method being quoted is the method of choice for the application, the bulk material measurement has the customary uncertainty, and the material, although a scrap/waste material, is still reasonably homogeneous and can be representatively sampled with a minimal uncertainty. In the case of U \& Pu IDMS, these target values include process and product materials, in addition to waste materials.

The DA Method Compendium provides target values for bulk solution volume measurements using a Ruska Electromanometer of $0.3 \%$ random error and $0.3 \%$ systematic error, referencing the DOE as the source for these target values. Although target values for the bulk measurement of solid materials are not provided in this document, the solution volume target values should be treated as the bounding case.

In cases where material homogeneity is poor or indeterminate, estimating random and systematic error components for this attribute is difficult to quantify and its impact upon representative sampling (and laboratory sub-sampling) further complicates the error propagation.

When the actual propagated measurement method uncertainty (i.e., random and systematic error combined linearly or as a root-mean square) is less than any of the other sources of accountability error, then the argument for requiring that measurement method target values be satisfied is not valid or cost effective. This is especially true for large errors from material inhomogeneity or nonrepresentative sampling since these error sources are so closely linked to the total uncertainty of the assay or concentration measurement. 


\section{Evaluation/Discussion, continued}

"Engineering Judgment" should $\underline{\text { not }}$ be the primary mechanism for estimating material homogeneity or sampling uncertainty for solid materials. Replicate samples and multiple measurements need to be taken until these sources of accountability error are quantified and then used in the calculations of the limit of error on inventory differences (LEID). Once these sources of error are quantified, they can be compared to the actual uncertainty of the analytical measurement method to determine if the stringent measurement method target values are really applicable. If improving the measurement methods random or systematic errors to achieve the target values would be complex, expensive, and/or impact mission objectives and would not result in a significant improvement in the LEID, then the measurement target value should not be treated as applicable.

Every step of the process, starting with the bulk material measurement, must be performed under well-controlled conditions. Hence a comprehensive measurement control program that includes quality control measurements at each step in the process is imperative.

\section{Discussion of SRS TIMS}

The $\mathrm{Pu}$ and $\mathrm{U}$ thermal ionization mass spectrometry (TIMS) methods implemented by the ALD/CLAS are designed to support process control, nuclear safety, and accountability measurements. The mass spectrometers are operated by a staff of twenty-four (24) technicians on a 24-hour per day, 365-day per year schedule. This analytical service is designed and funded to provide optimum sample throughput and turnaround time, with a measurement reliability consistent with overall operating requirements of the NMMD Nuclear Facilities providing the funding for these analyses. Accountability measurements by mass spectrometry include both plutonium and uranium isotopic distribution (U ISO; Pu ISO) and concentration/assay by isotope dilution (IDMS). Application of these measurement capabilities include:

- F-Canyon - PUREX Suspended March 2002

- FB-Line Material Characterization (Scrap Pu Oxides; Inhomogeneous/Suspect) [Pu ISO / Pu IDMS, U ISO / U IDMS]

- HB-Line Material Characterization (Scrap Pu Oxides; Inhomogeneous/Suspect) [Pu ISO / Pu IDMS, U ISO / U IDMS]

- H-Area Outside Facilities [U ISO / U DG Titration]

- HEU/LEU Program [U ISO / U DG Titration] *

- H-Canyon Output Accountability [U ISO / U DG Titration]

- H-Canyon Routine Physical Inventories [U ISO / limited U IDMS]

- H-Canyon Input Accountability [U ISO / U IDMS]

* U Davies-Gray Titration is used for uranium concentration in support of accountability, process control, and LEU product specification.

Each of these applications will be reviewed, in the order listed above for applicability of target values and compliance with applicable requirements. 


\section{Evaluation/Discussion, continued}

\section{$\underline{\text { F-Canyon PUREX Process }}$}

When the SRS was operating the PUREX process to produce weapons-grade plutonium the target values were clearly applicable. When the F-Canyon PUREX process was converted to a material disposition and stabilization process, a graded approach to target value requirements was appropriate. The typical F-Canyon feed for material stabilization contained much higher impurity levels and the isotopic distribution was outside of prior weapon-grade specifications. However, these variations in purity and isotopic distribution did not render the target values nonapplicable. These materials were still attractive to theft/diversion and International Target Values were still a good guide for input and output accountability. With the suspension of PUREX processing on March 2002, the target values are no longer applicable to the process control measurements now being provided in support of waste disposal and vessel flushing. Although no longer applicable, it is appropriate to note that TIMS Pu/U ISO measurements have met the stringent International Target Values since these values have been in existence. $\mathrm{Pu} / \mathrm{U}$ IDMS measurements had met PUREX material stabilization accountability needs, but were greater than the stringent International Target Value.

\section{$\underline{\text { FB-Line and HB-Line Material Characterization }}$}

Plutonium and mixed $\mathrm{Pu} / \mathrm{U}$ Oxides samples are submitted for characterization to determine/validate the disposition path and/or processing requirements. Measurements include $\mathrm{Pu} / \mathrm{U}$ ISO and $\mathrm{Pu} / \mathrm{U}$ IDMS (and may in the future include other measurements that have been applied more traditionally to accountability measurements). These oxide materials are often obviously inhomogeneous (as evidenced by simple visual inspection). NMMD applies an adequate/appropriate sampling process that obtains as representative a sample as possible given the nature of the bulk material. While the isotopic and assay information is used for both material characterization and accountability purposes, the International Target Values and the target values in the attached DA Methods Compendium are not applicable. The uncertainty due to inhomogeneity is significantly greater than any errors being introduced by the Pu/U ISO and $\mathrm{Pu} / \mathrm{U}$ IDMS. The Pu/U isotopic abundance method by TIMS was selected because it is the best method for the required isotopic abundance analysis. The $\mathrm{Pu} / \mathrm{U}$ concentration by IDMS was selected because:

- The method, with sample pretreatment and purification, is not seriously affected or challenged by the large and diverse distribution of impurity elements in these scrap/scrap-like materials;

- The assay method is approved for accountability measurement;

- The IDMS exceeded applicable data quality objective for the assay of these low-grade nuclear materials; and

- $\mathrm{Pu} / \mathrm{U}$ isotopic measurements were already required by TIMS and thus IDMS assay was a small increase in measurement scope that involved adding the ${ }^{244} \mathrm{Pu}$ and ${ }^{233} \mathrm{U}$ spike standards to the samples before the TIMS measurement. 


\section{Evaluation/Discussion, continued}

\section{$\underline{\text { H-Area Outside Facilities }}$}

The outside facilities are being used to hold the existing HEU inventories in preparation for HEU Blenddown to LEU for shipment to Nuclear Fuel Services (NFS) in Erwin, Tennessee. The current inventory is relatively static. However, when LEU production and shipping begin, the uncertainties associated with the laboratory measurements for $U$ isotopics by TIMS and $U$ concentration by Davies-Gray become increasingly important. The International Target Values for U ISO and U Titration should be treated as applicable, provided:

- The sample validation protocol is implemented (i.e., solution density agreement between replicates and minimum flush volumes are verified) using limits and controls that ensure optimum sampling reliability (not maximum acceptable sampling error); and

- The volume measurements are performed using Ruska Electromanometers that are maintained and controlled in an environment that consistently achieves the U.S. DOE Target Values for these devices.

Both the optimum sample validation and the Ruska enhancements are planned. However, the condition for applying the Ruska are not ideal and target values may not be achieved.

U isotopic by TIMS meets the International Target Values. U concentration by Davies-Gray will need to improve to meet this benchmark. The impact on the LEID from the actual uncertainty from the random and systematic errors of the Davies-Gray titration versus the target values should be examined. The accountancy benefit should justify the costs associated with improving the analytical measurement. The LEID should also be tested for impact using the possible ranges of uncertainties for bulk volume measurement and sampling uncertainty).

[If the cost is not excessive, it may be appropriate for ALD/CLAS to avoid any criticism even if the impact is small by replacing the existing methodology for Davies-Gray titration with the NBL high-precision Davies-Gray titration methodology to achieve the International Target Values for reliability.]

\section{H-Canyon Output Accountability}

H-Canyon Output Accountability for uranium isotopics is performed using TIMS. The CLAS method for U ISO by TIMS meets the International Target Values for uranium isotopic measurements. Refer to the preceding section on the H-Area Outside Facilities for a discussion of: plans for HEU/LEU processing (which will be fed by uranium product stream from the HMProcess); bulk volume and sampling reliability; and application of the Davies-Gray Titration for uranium concentration. H-Canyon accountability assay measurements by U IDMS (and $\mathrm{Pu}$ IDMS) have increased uncertainty due to multiple / part-time technicians performing measurement. It is appropriate to note that current sample validation requirements for output accountability are based upon a system of maximum allowable sample errors, not optimum sampling reliability. The differences between these methodologies can affect the applicability of the more stringent International Target Values, as the gain in LEID for achieving compliance can be insignificant relative to the cost. 


\section{Evaluation/Discussion, continued}

\section{$\underline{\text { H-Canyon Routine Physical Inventories }}$}

Refer to the preceding discussion on H-Canyon and H-Area Outside Facilities. Accountability measurements for uranium isotopics are performed by TIMS and uranium concentration by a variety of accountability methods. The impact of measurement uncertainty varies based upon the quantity of uranium in inventory at a given sample point. Sample validation is applied throughout the physical inventory sampling process, although the acceptance criteria is based on maximum allowable sampling error. The physical inventory is based upon multiple measurements, decreasing the significance of random errors. Target values for measurements should not be aggressively applied to all aspects of the physical inventory sample measurement process because of their decreased significance to the LEID.

\section{$\underline{\text { H-Canyon Input Accountability }}$}

Refer to the preceding sections for applicable discussion. Accountability measurements are performed using U ISO and U IDMS. The International Target Values are applicable, provided sampling error is minimized and bulk volume measurements meet DOE Target Values. Sample validation is currently based upon a maximum allowable sampling error methodology.

For additional information on Sample Validation, refer to ALD/CLAS procedures WSRC L3.0610059, "Sample Validation:, which is available on Shrine at the ALD Homepage: http://shrine01.srs.gov/analab/. [Click on the <<Procedure $>>$ button and then select manual L3.06.] Additional information is available in the technical basis package for this procedure, and from James Satkowski, CTF for Sample Validation (and from Michael K. Holland, author of this report and past CTF for Sample Validation). 


\section{Evaluation/Discussion, continued}

\section{Runs Rule:}

During the course of reviewing the International Target Values for accountability measurements, additional technical basis / justification was available for Central Laboratory Analytical Services' (CLAS) implementation of the "Runs Rule."

CLAS implements the "Runs Rule" using procedure WSRC L2-1-00118, "Accountability Method QC Chart Review," based upon the requirements in site procedure WSRC 14Q Procedure 3.10, "Determining and Responding to Control Limits." WSRC site-MC\&A has approved this implementing procedure. The CLAS implementation of the Runs Rule provides a 1-sigma precision range for acceptable systematic error. Eight consecutive measurements must exceed the same side of this 1-sigma central band before a systematic trend is considered to be significant (and thus require action by the method CTF to address the adverse trend).

The Runs Rule is not driven by the DOE Orders that govern nuclear material control and accountability. It is a statistical tool that has limitations when applied to analytical measurements. These limitations are addressed when the 1-sigma band is applied, especially for the high precision and accuracy measurements where the systematic uncertainty of the measurements is comparable to the systematic error of the standard used to assess measurement performance and trending. Reducing the Runs Rule below the 1-sigma level would require significant extra analytical expenses in the area of standards preparation, characterization, and maintenance. The required improvements in standards would be a major, unfunded initiative and is not likely to result in improvement to the control of the accountability measurements that are either significant or valuable relative to purpose for the measurements or the other sources of error associated with material accountability. For these reasons, a revision to procedure L2-100118 will not be initiated to change the CLAS implementation of the Runs Rule.

The International Target Values for each measurement technique/methodology (mass spectrometry, titration, coulometry, etc.) provide target uncertainty values (1-sigma) for both random and systematic error. In nearly all cases, the allowed systematic error component is set at the same value as the target for the 1-sigma random error component. The International Target Value system provides clear and direct indication that systematic error is a reality for all measurement methods, calibration methodologies, and standard materials. When short-term and/or long-term systematic errors total less than the 1-sigma random error, the systematic error component is at an acceptable level. When the systematic error of the measurement (or measurement system calibration, including the uncertainty of the standard) is within the 1-sigma precision range, it is not essential to determine the source of the systematic error (or to bias correct the measurement results). When the systematic error is tracked, trended, and controlled to ensure that it is small, then the pedigree of the measurement system is maintained and comparison of measurement performance versus the target values is valid. 


\section{Conclusions}

The International Target Values are excellent benchmarks for evaluating current performance versus established performance levels that are internationally accepted as state-of-the-practice for a measurement method. The DOE Target Values and the recommended performance criteria provided in the DA Method Compendium provide additional target value information to support this benchmarking process. It is the opinion of the author, based upon reviews of measurement performance within the DOE Complex and at international laboratories, that the state-of-thepractice benchmark for $\mathrm{Pu} / \mathrm{U}$ IDMS are significantly closer to the state-of-the-art capability for $\mathrm{Pu} / \mathrm{U}$ IDMS than is observed for the other destructive measurement methods having target values. The ITV for $\mathrm{Pu} / \mathrm{U}$ IDMS is achievable in a research environment or limited throughput application. The Pu/U IDMS target value benchmark may not be achievable under the current sample throughput, staffing, and funding conditions imposed in the ALD/CLAS. However, if the other sources of accountability errors are not minimized, then efforts to achieve the most restrictive target values for $\mathrm{Pu}$ IDMS and U IDMS will not be effective at reducing overall accountancy uncertainty. If the overall accountability uncertainty and LEID are not significantly reduced, then the effort is not cost effective and should not be treated as appropriate or applicable to the processing activity. Achieving the target values for these IDMS methods is not funded beyond those improvement activities that also support achieving required process throughput using a new spectrometer, [The new spectrometer was funded because it was needed to address throughput, down-time, and manufacturer-support issues.]

ITV are not applicable for the accountability-related activities currently supported by $\mathrm{Pu}$ isotopics by TIMS and Pu concentration by IDMS and Coulometry. However, Pu ISO by TIMS and $\mathrm{Pu}$ Coulometry both meet these stringent benchmarks. Target values for uranium isotopics by TIMS and uranium concentration by IDMS and Davies-Gray Titration are valid benchmarks, but imposing these benchmarks as strict requirements is only cost effective when all aspects of the accountability process are treated equally with regard to their impact on LEID.

The ALD/CLAS may wish to evaluate the NBL high-precision uranium titration methodology if current efforts to reduce random and systematic error in the standard Davies-Gray titration are not effective. 


\section{References}

1. IAEA Department of Safeguards Report STR-327, International Target Values 2000 for Measurement Uncertainties in Safeguarding Nuclear Materials, April 2001. [Also published as ESARDA Bulletin No. 31, April 2001.]

2. Destructive Analysis Method Compendium, DOE-NBL Report - Final Issue Pending. Working copy transmitted by DOE-NBL on May 1, 2002.

3. Memorandum SEO-MCA-2002-00032, "International Target Values as Goals for Facility Measurements Systems," from Edward T. Sadowski, WSRC-MPC\&A to Thomas L. Williams, DOE-SROO, January 31, 2002.

4. Memorandum TSD-CLS-2001-00070, "Application of the Runs Rule to Accountability Measurements in Central Laboratory Analytical Services," Robin H. Young, ALD/CLAS, and Michael K. Holland, ALD/AP to Scott E. Federman, ALD/CLAS, October 10, 2001.

\section{Attachments}

1. International Target Values 2000 for Measurement Uncertainties in Safeguarding Nuclear Materials, IAEA Report STR-327.

2. Destructive Analysis Method Compendium.

3. Memorandum SEO-MCA-2002-00032, "International Target Values as Goals for Facility Measurements Systems."

4. Memorandum TSD-CLS-2001-00070, "Application of the Runs Rule to Accountability Measurements in Central Laboratory Analytical Services."

\section{Appendix}

None 
Attachment 1

International Target Values 2000 for Measurement Uncertainties in Safeguarding Nuclear Materials

Page 1 of 48

\section{International Target Values 2000 for Measurement Uncertainties in Safeguarding Nuclear Materials}

H. Aigner, R. Binner, E. Kuhn

IAEA, P. O. Box 100, A-1400 Wien, Austria

U. Blohm-Hieber

European Commission, Euratom Safeguards Office, Plateau du Kirchberg, L-2900 Luxembourg, Luxembourg

K. Mayer (ESARDA WGDA)

European Commission, JRC, Institute for Transuranium Elements, Postfach 2340, 76125 Karlsnuhe, Germany.

S. Guardini (ESARDA WGDA)

European Commission, JRC, Institute for Systems, Informetics and Safety, I-21020 Lspra (VA), Italy

C. Pietri (ANSI/NMM)

HITECH Consuliants, 5506 Grand Ave., Westem Springs, Il 60558, USA

B. Rappinger (ISO/TC85/SC5/WG1)

Westinghouse AB, BQC, SE-72163 Vasteras, Sweden

B. Mitterrand (ISO/TC85/SC5/WG3)

COGEMA La Hague, Beaumont-Hague CEDEX F-50444, France

\section{J. Reed (ISO/TC85/SC5/WG12)}

BNFL Sellafield, B229 Sellafield, Seascale, Cumbria, CA201PG. United Kingdom

O. Mafra-Guidicini (ABACC)

ABACC. Av. Rio Branco 123/515, Centro, Rio de Janeiro, RJ 20040-005, Brazil

S. Deron

Consultant, IAEA, P. O. Box 100, A-1400 Wien, Austria 


\title{
Attachment 1
}

\author{
International Target Values 2000 for Measurement Uncertainties in Safeguarding Nuclear \\ Materials \\ Page 2 of 48
}

\section{Notice}

This paper is the Millennium Edition of the International Target Values (ITVs) and contains some minor corrections from the version originally published in the International Atomic Energy Agency report STR-327 dated April 2001. In addition, certain non-essential sections of the original report have been removed to reduce the length of this articte for publication. Additional comments on the ITVs by the reader are solicited and should be sent to Charles Pietri at cpietri@aol.com for response.

\begin{abstract}
This issue of the International Target Values (ITVs) represents the fifth revision, following the first release of such tables issued in 1979 by the ESARDA/WGDA. The ITVs are uncertainties to be considered in judging the reliability of analytical techniques applied to industrial nuclear and fissile material, which are subject to safeguards verification. The tabulated values represent estimates of the "state of the practice" which ought to be achievable under routine measurement conditions. The most recent standard conventions in representing uncertainty and reliability data have been considered, while maintaining a format that allows comparison with the previous reteases of the ITVs. The present report explains why target values are needed, how the concept evolved and how they relare to the operator's and inspector's measurement systems. The ITVs 2000 are intended to be used by plant operators and safeguards organizations, as a reference of the quality of measurements achievable in nuclear material accountancy, and for planning purposes. The report suggests that the ITVs can be used with benefit for statistical inferences regarding the significance of operator-inspector differences whenever valid performance values are not available.
\end{abstract}


Attachment 1

\author{
International Target Values 2000 for Measurement Uncertainties in Safeguarding Nuclear \\ Materials \\ Page 3 of 48
}

\title{
1. Introduction
}

Safeguarding nuclear material involves a quantitative verification of the accountancy of fissile materials by independent measurements. The effectiveness of these verifications depends to a great extent upon the quality of the accountancy measurements achieved by both the facility operator and the safeguards inspectorate. For this reason a typical model of Safeguards Agreements $^{|1,2|}$ stipulates that:

"The Agreement should provide that the system of measurements on which the records used for the preparation of reports are based shall either conform to the latest international standards or be equivalent in quality to such standards".

Although the above requirement was directed to the facility operators, it indeed applies equally well to the safeguards inspectorates.

In the absence of relevant international standards of measurements, the International Atomic Energy Agency (IAEA) had defined in the 1970s a set of international standards of nuclear material accountancy ${ }^{(3)}$, which lists the "expected measurement accuracy associated with the closing of a material balance" at five different types of nuclear facilities. However, these values have never been reviewed despite numerous technological changes since their adoption by consensus by a group of experts designated by their Governments. Safeguards officials and evaluators but also plant measurement specialists need more current and informative references regarding the performance capabilities of measurement methods used for the determination of the volume or mass of a material, for its sampling, its elemental and isotopic assays. Such information is needed for the various nuclear materials encountered in the nuclear fuel cycle.

The Working Group on Techniques and Standards for Destructive Analysis (WGDA) of the European Safeguards Research and Development Association (ESARDA) pioneered the way in 1979 by presenting a list of "Target Values" for the uncertainty components in destructive analytical methods ${ }^{[1]}$ to the safeguards authorities of Euratom and of IAEA. Revised estimates were prepared in collaboration and published as the 1983 Target Values ${ }^{(5)}$ after four years of extensive discussion and consultation with and within operators' laboratories and safeguards organizations. The international acceptance of the concept grew further with the next review, which involved, besides the ESARDA/WGDA and IAEA, the active participation of the members of two specialized committees of the Institute of Nuclear Materials Management (INMM). The 1987 Target Values, published as a result of this review ${ }^{19}$, defined, like the previous editions, the values of "random" and "systematic" error parameters to be aimed for in elemental and isotopic analyses of the most significant types of materials using common destructive analytical methods. The same groups took a new step when they agreed to define with the 1988 edition $^{\text {(1) }}$ the values of the random error parameter to be met in the elemental assays as a result of sampling. Unfortunately, it was not possible at this time to include values for sampling uncertainties arising from systematic effects.

Following a 1988 recommendation of the IAEA Standing Advisory Group on Safeguards Implementation (SAGSI), the IAEA convened a Consultants Group Meeting in June 1991 to provide expert advice on intemational standards of measurements applicable to safeguards data A concept of International Target Values (ITVs) was proposed on the model of the 1988 ESARDA Target Values and included estimates of the "random and systematic error" uncertainties originating from the measurements of volumes or masses of nuclear materials. The scope of ITVs was also extended to include a consideration of the non-destructive assay methods (NDA) which had won acceptance as accountancy verification tools.

Specialists from four continents took part in the discussion of the proposed concept. The ESARDA/WGDA held joint meetings with the ESARDA Working Group on NDA methods (ESARDA/WGNDA). The LAEA organized a series of Consultants Group Meetings with the 


\title{
Attachment 1
}

\author{
International Target Values 2000 for Measurement Uncertainties in Safeguarding Nuclear \\ Materials \\ Page 4 of 48
}

participation of a representarive from a large European reprocessing plant, of Brazilian and Japanese nuclear national authorities along with representatives of ESARDA, INMM, the International Organization for Standardizarion (ISO), the European Commission (EC) and LAEA inspectorates. The result was the publication of an IAEA Safeguards Technical Report in March 1993, titled "1993 International Target Values for Uncertainty Components in Fissile Isotope and Element Accountancy for the Effective Safeguarding of Nuclear Materials" ESARDA Bulletin ${ }^{\text {t9 }}$ and in the Journal of the INMM ${ }^{\text {(t) }}$, widely publicized the IAEA technical report. The report itself was translated into Japanese ${ }^{[11 !}$.

International experts and panels have now reviewed the experience gained with the use of the 1993 ITVs and the progress made since 1993 in accountancy and safeguards verification measurements. These include ESARDA/WGDA. ESARDA/WGNDA, the Institute for Nuclear Material Management (INMM), the Japanese Expert Group on ITV 2000, Working Groups of the International Standardization Organization (ISO) dealing with analytical measurements in nuclear fuel industry and the Brazilian/Argentinean Agency of Accountability and Control of Nuclear Materials (ABACC). This report contains the changes made in the presentation of the ITVs and in some of the target values to reflect the latest recommendations of the experts.

An effort was made to bring the nomenclature in line with the latest recommendations of ISO ${ }^{121}$, the National Institute of Standards and Technology (NIST) ${ }^{[13 \mid}$ and the European Association of Chemical Measurements (EURACHEM) ${ }^{164}$. A clear distinction for example is made between the meaning of the term "error" and the term "uncertainty". The ITVs 2000 indeed represent target standard uncertainties, expressing the precision achievable under stipulated conditions. These conditions typically fall in one of the two following categories: "repeatability conditions" nomally encountered during the measurements done within one inspection period; or "reproducibility conditions" involving additional sources of measurement variability such as "between inspections" or "between laboratories" variations.

As in earlier publications the values listed in the present document have been derived from an evaluation of actual measurement data. Four sources of information were considered. The most relevant and complete set of measurement data still comes from the information gathered by safeguards inspectorates during the statistical cvaluation of the results of the measurements reported by the facility operators and the results of independent measurements performed on the same materials by the inspectors ${ }^{\text {i5,16. }}$. This approach will be referred to as the "top-down" approach. These data were complemented and confirmed by "bottom-up" assessments of measurement uncertainty components published by measurement specialists ${ }^{\left[17-2 x^{2}\right]}$ and derived according to the ISO ${ }^{124}$, NIST ${ }^{[13]}$ and EURACHEM ${ }^{[14}$ guides. In addition and whenever possible, it was verified that the proposed ITVs were consistent with the results of laboratory intercomparisons $s^{[77-33]}$ or measurement quality evaluation programmes ${ }^{[34-4]}$. In cases where little or no staristical data was available (particularly for sampling uncertainties), some values were defined on the basis of expert opinion.

The ITVs 2000 bear a date like the ESARDA Target Values and 1993 ITVs issued previously. This reflects the experience that the quality of measurements may improve with the development of newer methods and instruments. ITVs also reflect the current understanding of the structure of the uncertainty components in nuclear material accountancy measurements. Changes can also occur in the future as this understanding improves or varies.

As with the previous lists, the ITVs 2000 should be achievable from today forward under the conditions normally encountered in typical industrial laboratories or during actual safeguards inspections. They do not represent the measurement uncertainties, which would only be achieved under exceptional or ideal laboratory conditions, or with most recently developed methods, which have not yet found wide use for daily and routine measurements.

Significant changes in the application of instruments and techniques have taken place since the previous edition. Measurements with instruments like high level neutron coincidence 


\title{
Attachment 1
}

\author{
International Target Values 2000 for Measurement Uncertainties in Safeguarding Nuclear \\ Materials \\ Page 5 of 48
}

counters (HINC), K-edge X-ray absomptioneter and fluorescence analyzers (HKED) are used routinely at the plants by inspectiors with great success, not only to detect partial defocts but also to vertfy the flow and balance of nuclear materials. This has allowed to decrease strongly the fraction of items, which need to be verified by chemical analysis. The latter methods are used now mainly for verifying the quality of operators" measurement systems and the absence of small but measurable biases in the closing of the material balances. Here. improvements were also observed with the combined use of Large Size Dried Spikes (LSD) and thermal ionization mass spectrometers with multidetectors and total sample evaporation for the verification of the uranium and pitutonium content in spent fuel solutions and U/Pu fuel materials by isotope dilution mass spectronerry (DMS).

It is expected that the ITVs 2000 will continue to be a motivating goal for beginner laboratories and a teasonable reference for experienced laboratories and safeguards evaluators. With the growing acceptance of modem quality assurance concepts it is suggested that the ITVs 2000 can also constitute a good reference against which analytical laboratories would validate theit measurement system. 


\title{
Attachment 1
}

\author{
International Target Values 2000 for Measurement Uncertainties in Safeguarding Nuclear \\ Materials \\ Page 6 of 48
}

\section{Safeguards Accountancy Verification Measurements}

As evident from the title of the report and the introduction, the principal application of the ITVs should be in safeguards activities. The safeguards verification data also form the major source of information on which the ITVs are based. A description of the origin of the safeguards data is therefore relevant.

Figure 1 describes the basic measurement scheme followed in safeguards measurement verifications. For each inspection, $j$, the inspector selects, in accordance with a random sampling plan, the items or batches of nuclear marerials to be verified by an independent measurement. The inspector then compares the result of his verification measurement, $Y_{i,}$ to the result, $X_{i j}$, which the operator has obtained on the same batch or iten $i$, and which the operator has declared to the inspectorate. The ability of the inspector to detect whether the difference $d_{i j}$ is significantly different from zero depends upon the overall uncertainties in the results $X_{i j}$ and $Y_{i j}$. Figure 1 identifies the major steps of the measurement process where uncertainties can arise, although not all steps may be relevant for every method (c.g., several of the steps may be omitted or combined under a single step for NDA methods).

Step 1 corresponds to the measurement of the volume or mass of the item or batch of material. This so-called "bulk" measurement, when needed, takes place in the plant area and involves a calibration procedure.

Step 2, the "sampling", involves removing, for the purpose of the analytical measurement, a representative portion of the material from the batch or item to be analyzed. This portion may be a complete item in the case of an NDA measurement. This step is also done in the plant area.

Step 3 concerns the precautions which must be taken in the way the sample is "conditioned" and packaged at the sampling starion so that all characteristics to be measured are preserved during its transport to the location or laboratory where the characteristics will be measured ${ }^{(4)}$.

Step 4, the "shipment", is the transport of the sample to the location where it can be measured. This is rarely a trivial operation even when the movement is very short, as in the case of an NDA measurement, which is often done practically on the spot.

Step 5, the "treatment", is intended to bring the sample into the most appropriate geometrical, physical and/or chemical form for the measurement. This step is skipped when a complete item is subject to an NDA measurement. The creatment of a sample taken for destructive analysis may involve a sequence of individual steps, such as subsampling, dissolution, dilution, spike or standard addition, chemical treatment or chemical separation, etc.

Step 6, represents the "measurement" itself. In general terms, a measurement is based on a calibration from which the parameters linking the observed signal and the measurand are determined. Typical examples are HLNC calibration curves for Pu mass determination, calibrations of Gamma Spectrometers for ${ }^{25} \mathrm{U}$ abundance determination or the determination of the mass-discrimination correction factor for a mass-spectrometer. The standardization of a titrant solution is another example of a calibration, although it is frequently not recognized as such. Calibration functions may be as simple as a single calibration factor (actually representing a straight line through the origin), or may be complex and represented by an empirically determined calibration curve. Calibrations based on recognized references, such as certified reference materials or well-known physical constants, establish the traceability chain between the measurement result and the International System of Units (SI). Calibrations may be valid and used without modifications for long times, repeated on a daily basis or even performed with each individual measurement. Sometimes, calibration is performed in two steps: elaborate calibration exercises for determining the fundamental characteristics of the calibration function are 


\title{
Attachment 1
}

\author{
International Target Values 2000 for Measurement Uncertainties in Safeguarding Nuclear \\ Materials \\ Page 7 of 48
}

combined with more frequently repeated "normalization" measurements to correct for short-term effects or minor deviations from the overall calibration function at the specific working range.

Step 7, the "calculation", consists in transforming the results of the physical or chemical measurement obtained in the preceding step into an estimate of the amount of fissile element or isotope in item or batch $i$. Particularly when the operator and inspector use DA, this involves estimating the total element content, by combining the result of the bulk measurement $w_{i}$ with the elemental concentration $c_{i r}$. In the case of Uranium materials, this is combined with the isotope abundances $f_{4}$ of the fissile isotope $\left({ }^{23} \mathrm{U}\right.$ or $\left.{ }^{23} \mathrm{U}\right)$ to yield a measure of the amount of fiecila iestops in itam or bateh i, nooording to aquationo (1) and (2), respcetively.

$$
\begin{aligned}
& \left.X_{i j}=w(O)_{i j} \cdot c(O)_{i j} \cdot f O\right)_{i j} \\
& Y_{i j}=w(I)_{i j} \cdot c(l)_{i j} \cdot f(I)_{i j}
\end{aligned}
$$

Every stage of the process, starting with bulk measurements must be performed under well-controlled conditions. Hence quality control measures are imperative at every step of the process. Quality control on sampling can be done by taking replicate samples after different mixing times or taking samples from a number of items of the same batch of bulk materials. Quality control materials or samples can be introduced at specific steps to monitor the quality of the whole process or any part of it, including the conditioning and shipment steps. Figure 1 shows an example where control materials are used independently by the operator and the inspector to check the quality of the processes following the sampling. Quality control measures should be performed in the frame of a documented quality system ${ }^{\mid-3.53]}$.

The uncertainties in the measurements of element concentrations and isotope abundances in the ITV refer to the combined effects of the uncertainties in Steps 3 to 6 occurring after the taking of the sample in Step 2.

Step 8, the "reporting" of the results, is purely clerical but unfortunately it can be a source of errors. Uncertainties arising from such errors are not considered in the ITVs proposed in this document. Yet it is essential that appropriate quality assurance meastures be taken to avoid the occurrence of clerical errors.

When NDA is used the attention focuses most on the measurement (Step 6) as the preceding steps have usually less impact or may even be omitted. For example, bulk measurements and sampling are not needed if the NDA method allows direet measurement of the total amount of fissile element or isotope contained in a whole item or batch of nuclear material, as with various neutron counters or calorimeters. 
Attachment 1

International Target Values 2000 for Measurement Uncertainties in Safeguarding Nuclear Materials

Page 8 of 48

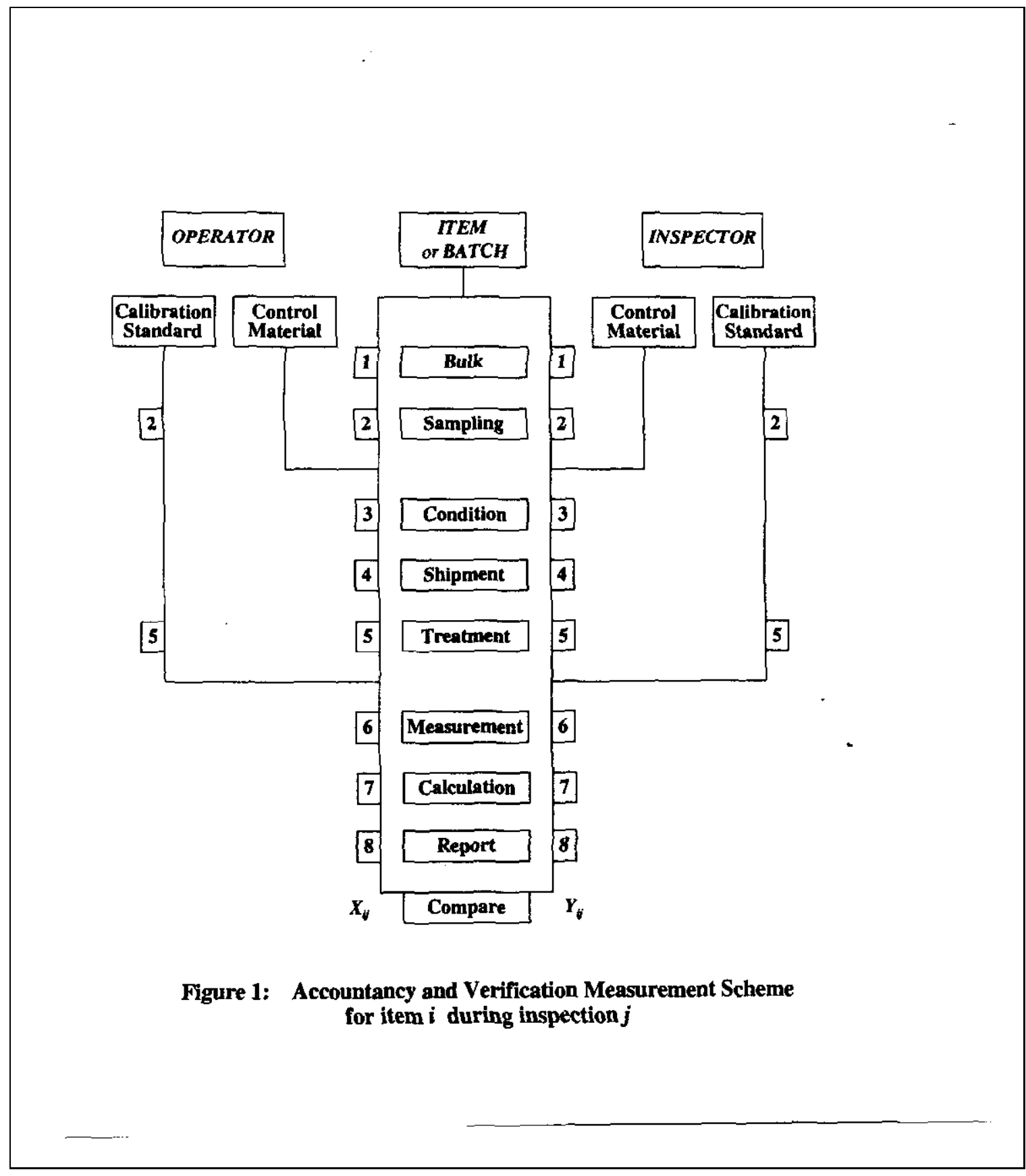




\title{
Attachment 1
}

\author{
International Target Values 2000 for Measurement Uncertainties in Safeguarding Nuclear \\ Materials \\ Page 9 of 48
}

\section{Evaluation of Safeguards Accountancy Verification Measurements}

The statistical terms used in this document are defined in Annex 1 in an effort to promote the understanding of the statistical concepts used here.

The safeguards inspectors examine the operator-inspector paired differences to determine whether these remain within upper and lower limits, which are commensurate with the characteristic uncertainties of the operators' and inspectors' measurement systems. For this purpose, the inspectors need to quantify the major uncertainties of the actual data collecred during their verification acivivies.

Two categories of uncertainties play an important tole in planning for inspections and in drawing inferences from inspection data: uncertainties due to repeatability effects, which are of a purely random nature, and uncertainties resulting from systematic effects within a given set of data, corresponding to an inspection period ${ }^{[3453}$. These uncertainties will be designated by the symbols $\mathbf{u ( r )}$ and $\mathbf{u}(\mathbf{s})$, respectively:

- random uncertainty corsponents, $u(r)$, are due to errors varying in an unpredictable way atnong individual items or results. Counting statistics or the repeatability of measurements within a short period of time under constamt conditions are typical examples for random uncertainty sources. Simply stated, the effects of random uncertainties can be reduced by repeated measurement. sampling and analysis, but it is not possible to correct for random errors.

- uncertainty components of a systematic character, u(s), are due to errors affecting an entire group of items in the same way, like all measurement results interpreted with the same calibration curve, nomalized with the same normalization experiments, or affected by the same background subtraction. But also uncertainties in the certified values of reference materials, nuclear data uncertainties or constant instrument or laboratory biases will appear to have a systematic character. The effects of uncertainties of a systematic character cannot be reduced by reperition under a fixed set of conditions encountered during a given inspection period. The cause of systemaric ermre may ho knowm or unlmomn. If beth the cause and the value of a systematic error are known, it can be contected for, but there will still remain an uncertainty component of systematic character, which is associated with this correction.

A basic assumption is that $u(r)$ and $u(s)$ are characteristics of the type of material, its chemical and physical form and of the method of measurement. A further assumption is that the component of systemaric character, $u(s)$, is constant for a given inspection period, but that it varies in a random manner from one inspection to another, for both the operator and the inspector.

Consequently, the inspectors group the data pairs originating from one inspection period, $j$, by material balance areas (MBA), by strata of materials of similar characteristics and by measurement methods ${ }^{130}$. For a given MBA and stratum, call:

$$
\mathrm{d}_{\mathrm{i}}=\left(\mathrm{X}_{\mathrm{i}}-\mathrm{Y}_{\mathrm{i}}\right) / \mathrm{X}_{\mathrm{j}}
$$

the operator-inspector difference, $\mathrm{d}_{i j}$, for item $i$ in inspection $j$, with

$$
i=1, m
$$




\section{Attachment 1}

\section{International Target Values 2000 for Measurement Uncertainties in Safeguarding Nuclear Materials \\ Page 10 of 48}

$$
\mathrm{j}=1,2, \ldots, \mathrm{K}
$$

Note: to simplify the presentation, relative differences are treated here. In prartice, absolute differences, $\left(X_{i j}-Y_{i j}\right)$, would be used when the size of the items of a given stratum vary widely.

The assumed error model is

$$
d_{i j}=d+A_{j}+\varepsilon_{i j}
$$

where

- $d \quad$ is the mean difference over the $\boldsymbol{K}$ inspections,

$-\Delta$ is the systemacic error of the operator-inspector difference during inspection $j$. and

- $\varepsilon_{\mathrm{ij}} \quad$ is the random enror of the operator-inspector difference for item $i$ during inspection $j$.

The expected values of $\Delta$ and $\varepsilon$ are both zero (i.e., they are both centred random variables in a statistical sense). An analysis of variance components of the operator-inspector differences, $d_{i j}$, according to this model equation gives estimates of the variance $s^{2}(\varepsilon)$ of the random component and of the variance $s^{2}(\Delta)$ of the component due to systemaric effects within the given inspection period ${ }^{[56-54}$ In performing this analysis of variance components, it is generally assumed that $\Delta_{j}$ and $E_{i j}$ are normally distributed and that the variances of the random error are the same for all inspections. The set of results are therefore screened for outliers prior to performing this evaluation.

Paired comparisons of this type are done separately for bulk measurements, element concentrations and isotope abundances, as well as for the masses of fissile elements and isotopes. One obtains, for cach type of measurement, an estimate of the combination of the actual uncertainty components for the operator's and inspector's measurement systems:

$$
\begin{aligned}
& s^{2}(\varepsilon)=u^{2}(r, O)+u^{2}(r, I)-2 r(\varepsilon) u(r, O) u(r, I) \\
& s^{2}(\Delta)=u^{2}(s, O)+u^{2}(s, I)-2 r(\Delta) u(s, O) u(s, I)
\end{aligned}
$$

where

- $u(r, O)$ and $u(r, \Gamma)$

are the standard uncertainties due to random error components for the operator and the inspector respectively.

- $r(\varepsilon)$ is the Pearson correlation coefficient between the operator's and the inspector's random errors,

and

- $u(s, O)$ and $u(s, D) \quad$ are the standard uncertainties due to effects of systematic character for the operator and the inspector respectively

- $r(\Delta) \quad$ is the Pearson correlation coefficient between the operator's and inspector's systernatic errors.

It can be expected that the uncertainties of operator's and inspector's data have similar magnitudes when both are obtained with similar methods. Under the assumption that the ertors of the operator and of the inspector are independent from each other, i.e.

$$
r(\varepsilon)=r(\Delta)=0
$$

the values 


\section{Attachment 1}

\section{International Target Values 2000 for Measurement Uncertainties in Safeguarding Nuclear Materials Page 11 of 48}

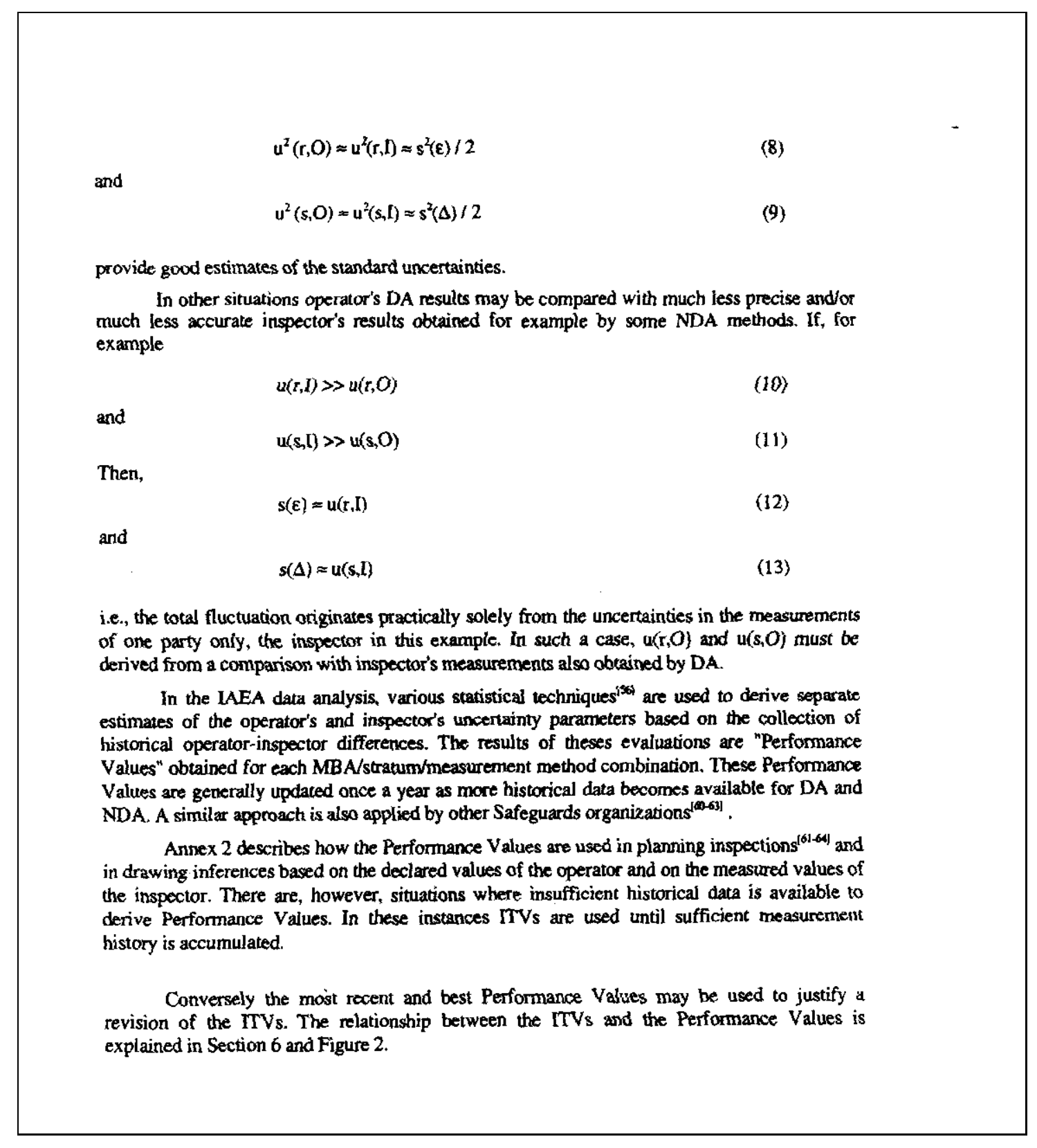




\title{
Attachment 1
}

\author{
International Target Values 2000 for Measurement Uncertainties in Safeguarding Nuclear \\ Materials \\ Page 12 of 48
}

\section{Results of Laboratory Intercomparisons}

Laboratory intercomparisons also offer a documented set of relevant experimental data for defining Target Values. The most useful information stems from experiments, where the participants analyze very well characterized maicrials or measure well knownt volumes or masses of nuclear maserials in industrial tanks or containers, and where their results are directly compared to the certified composition of the maserials or to the certified value of the respective quantities. Permanent or periodic measurement evaluation programmes have a greater value for our present purpose than one-shot intercomparison experiments, because the participants tend to follow more closely the ir routine measurement procedure when the intercomparison samples are submitted sufficiently frequently.

The Insitute for Reference Materials and Measurements (IRMM, Geel), the Commission d'Etablissement des Methodes d'Analyse (CETAMA) of the Commissariat a IEnergie Atomique (CEA, France) and the New Brunswick Lahoratory at Argonne (NBL, USA) administer such programmes in the area of nuclear material measurements. The discussion of the present edition of the MVs made extensive reference to the reports published on the results obtained in the

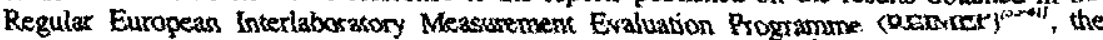
programme of Evaluation de la Qualite des Résultak d'sualyses dans Industrie Nucléaire (EORAN) respectively by thise dree organizations. The calorinetry Exchange Programme of the Mound

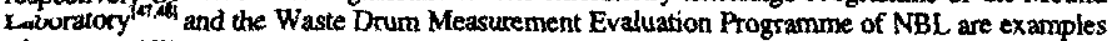
of too rare NDA measurement evaluation programmes. Unfortunately also, there exists still no permanent measurement evaluation programme regarding bolk measurements and the quatity of sampling procedures.

Mass measurements are rather straightforward, so that actual inspection data grobably provide sufficiently reliable estimates of their uncertainties. The measurement of volumes of solutions in incustrial tanks using pneumatic level indicators is a more complex procedure and has been the object of sevecal scientific experinents with international particination. The results of these experiments have been reported ${ }^{20 x+y}$ and were used in the discussion of the retevant Target Values. The uncertaintits to be expected in the use of tracer techniques for volume measurements have been evaluated in the same or similar experiments ${ }^{16.0773}$.

There are numerous references of interest regarding one-shot intercomparisons of the quality of elemental and isotopic assays by $\mathrm{DA}^{\text {i2(23),7476) }}$ as well as extensive intercompatisons of non destructive measurements by ganma spectronetry in waj,

The evaluations of such one-shot experiments are tsually much mote elaborate than those of actual inspection data or those of permanent measurement evaluation programmes. They provide, therefore, a better insight into the structure of the soutces of measurement uncertainties.

A frequent drawback of interlaboratory comparisons is that they too rarely involve the measurements of actual industrial materials under industrial conditions. The report of the cooperative certification of working reference materials of plutonium and uranium oxides for NDA constitute exceptions ${ }^{\text {thim }}$

The ITVs 2000 were defincd to be consistent with the standard uncertainties observed in the most recent interlabotatory comparisons and measurement evaluation programmes involving the use of current technologies, with due consideration to the comments made above. 


\title{
Attachment 1
}

\author{
International Target Values 2000 for Measurement Uncertainties in Safeguarding Nuclear \\ Materials \\ Page 13 of 48
}

\section{Results of Method Validations and Quality Control Measurements}

The experimental validation of measurement methods has become a standard practice for metrological and analytical laboratories required by most quality systems. Consolidated guidelines for the standardized performance of such studies are just enverging, however $r^{132}$ of . This sometimes makes it difficult to compare the respective results obrained by different laboratories. The most trustworthy studies of this type are certainly those which identify the basic metrological parameters of the measurement process, estimale the contributions of the uncertainties occurring in these elementary steps, and compare the expected performance with the results of actual measurements of well-known amounts of material $s^{17-2541-91 !}$. When the uncertainty propagation model yields larger values than the experimental determinations of the total uncertainty, it is probable that the design of the experiments failed to include one or several sources of potential uncertainties. These cases must receive specific aftention. The ESARDA/WGNDA has undertaken a comprehensive examination regarding the propagation of the uncertainties in NDA measurements for safeguards, and in general to the Quality Control and

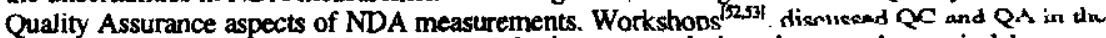
wholo provess ur INDA assay, starung with the instrument design, down to the use in laboratory conditions, in verification measurement, preparacion and use of RMs, traceability, qualification and certification of the measurement results.

The reports on the developments of isotope dilution mass spectrometric assay of spent fuel solutions using Large Size Dried (LSD) Spikes ${ }^{927}$, metal spike ${ }^{931}$, internal standard ${ }^{(294}$ and total evaporation techniques (TET) ${ }^{\text {s91 }}$ were considered with a particular interest because the analyses of spent fuel dissolver solutions at large reprocessing plants should be of the highest possible accuracy.

The EURACHEM document ${ }^{144}$ contains model cases for the uncertainty propagation for various types of analytical techniques. The LAEA is preparing a technical report on the propagation of uncertainties in radiochemical measurements and nuclear material analyses ${ }^{[96]}$. The latter report includes examples dealing with uranium and plutonium assays of spent fuel solutions by isotope dilution mass spectrometry (IDMS), $\alpha$-spectrometry and Xray fluorescence analysis (XRFA). These documents describe how the elementary sources of uncertainties in each step of the assay are identified. This leads to the expression of the final result, $y$, as a function of the elementary parameters of the assay, $x_{i}$ :

$$
\left.y=f\left(x_{i}\right)\right)
$$

The combined uncertainty ${ }^{(12-14}$ can be derived according to equation (15) when the $\left(x_{i}\right)$ are actually independent variables:

$$
u_{E}^{2}=\sum_{i} c_{i}^{2} \cdot u_{i}^{2}
$$

$$
\begin{aligned}
& \text { where } H_{c} \text { is the combined standard uncertainty for the assay result } y \\
& u_{i} \text { the standard uncertainty for parameter } x_{i} \\
& c_{i} \quad \text { a coefficient of sensitivity defined in equation (16) below. }
\end{aligned}
$$

$$
c_{i}=\left(y / x_{i}\right)
$$




\title{
Attachment 1
}

\author{
International Target Values 2000 for Measurement Uncertainties in Safeguarding Nuclear \\ Materials \\ Page 14 of 48
}

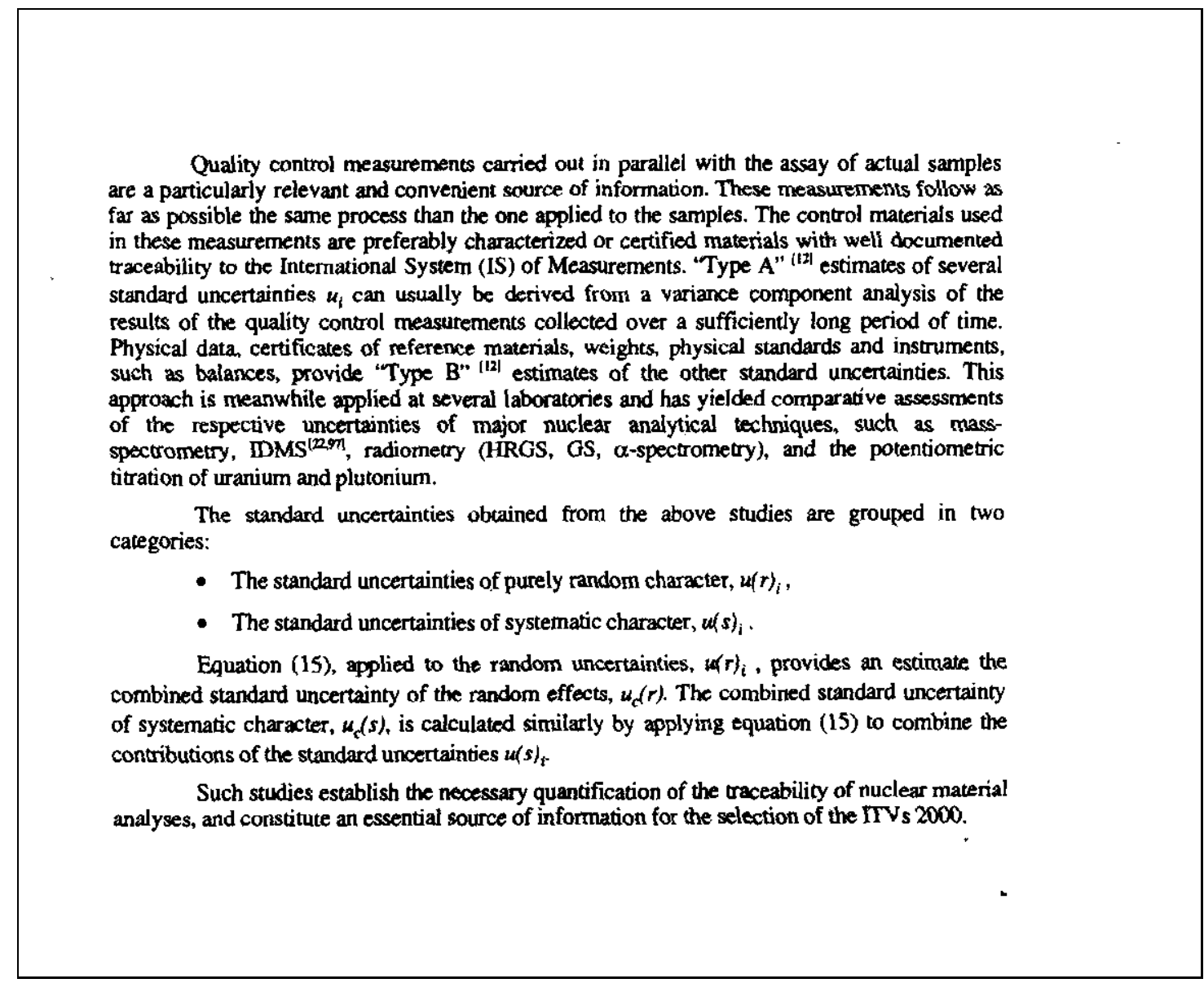




\title{
Attachment 1
}

\author{
International Target Values 2000 for Measurement Uncertainties in Safeguarding Nuclear \\ Materials \\ Page 15 of 48
}

\section{Meaning of International Target Values 2000 for Uncertainty Components}

The International Target Values 2000 for Measurement Uncertainties (ITVs 2000) are values for uncertainties associated with a single determination result; e.g., this may be the result reported by one laboratory on one sample (independent of the analytical scheme applied internally in the laboratory), or the result of an NDA measurement performed on a single item. The ITV 2000 take into account actual practical experiences and should be achievable today under the conditions normally encounteted in typical industrial laboratories or during safeguards inspections.

The ITVs 2000 were selected on the basis of a critical discussion of the inspectorates' performance evaluations of actual hiscorical data and their comparison with the 1993 ITVs. They are also chosen to be consistent with uncertainty assessments provided by:

- experimental validarion of measurement methods and instrumentation,

- interlaboratory measurement evaluation programmes, or

- individual laboratories.

The ITVs 2000 are applicable to the accountancy data collected by the inspectorates. They do not represent the ultimately achievable performance of a measurement system, which would be obtained under exceptional or ideal laboratory conditions. However, they reflect reasonably well the progress observed during the past several years in the routine performance of measurements done for the purpose of material accountancy and verification.

Figure 2 visualizes the conceptual relationship between Performance Values and ITVs. Pefformance Values are described by a range of values of the parameters measuring the uncertainties observed during actual industrial operations and safeguards inspections. This range is sometimes said to represent the State-of-the-Practice. The uncertainties achieved under "ideal" conditions by research laboratoties or laboratories producing and cenifying primary reference materials can be represented by another range of values which may be taken to illustrate the State-of-the-Art in analytical measurements. At a given time, the two ranges of values can overlap to various degrees depending upon the nature of the measurement and the spread of analytical technology advances at that time. The ITV for a given type of measurement is a single value, which has been selected to be a goal of acceptable level, achievable in practice.

The TTVs 2000 intend to take also into account all sources of measurement uncertainties, including sources which may not be apparent in Performance Values resulting from paired comparisons of operator's and inspector's measurements. 
Attachment 1

International Target Values 2000 for Measurement Uncertainties in Safeguarding Nuclear Materials

Page 16 of 48

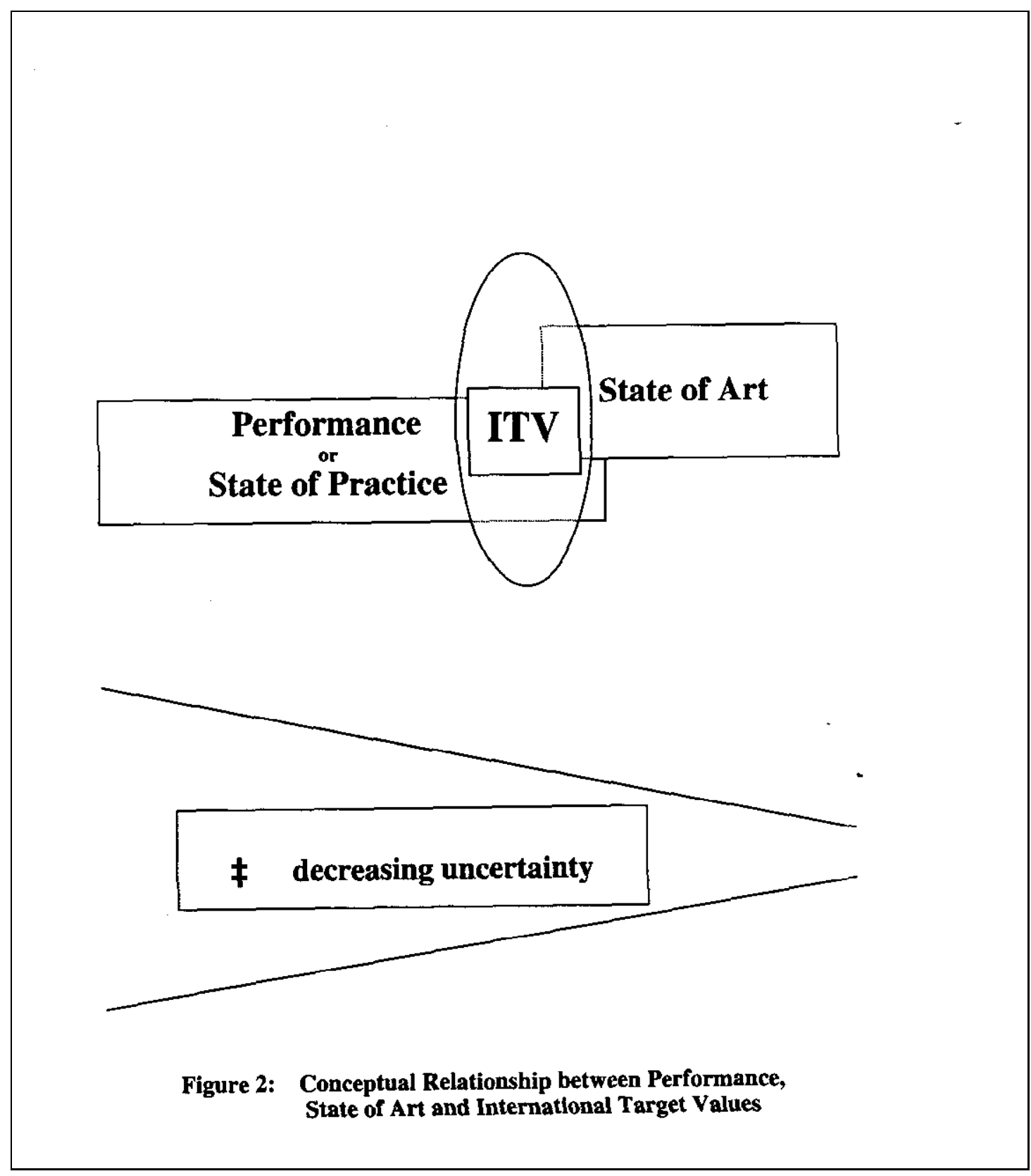




\title{
Attachment 1
}

\author{
International Target Values 2000 for Measurement Uncertainties in Safeguarding Nuclear \\ Materials \\ Page 17 of 48
}

\section{Structure and Content of the ITVs 2000}

The presentation of the 1993 ITVs involved 16 different tables. A different format was chosen for the presentation of the ITVs 2000 , which include only 7 tables.

- Table 1 provides a list of the codes used to identify the measurement methods in Tables 2 to 7 . The methods used by the IAEA are described briefly in Reference [98].

- Tables 2 to 6 list the ITVs 2000 for bulk and density measurements, sampling, the determination of element concentration, of ${ }^{23} U$ isotope abundance, and of plutonium isctope ratios, tespectively.

- ITVs for total amount of fissile element or isotope are given in Table 7 for NDA techniques providing a direct measurement.

- Each table identifies separate ITVs according to the type of material and measurement method, as appropriate.

- Two parameters, $u(r)$ and $u(s)$, characterize the quality, which should be aimed for in a specific measurement of a given material using a specified method at a single laboratory; $u(r)$ and $u(s)$ are specific subsets of the combined standard uncertainty comprising all uncertainties arising from random effects and systematic effects, respectively, according to the description in chapter 3.

These parameters should include all uncertainty components, which determine the potential difference between the measured and the true value. For example, the values specified for the element and isotope concentration measurements include all uncertainties generated in steps 3 to 6 of Figure 1 as well as the uncertainties of the calibration measurements, and the uncertainties of the reference data and materials used for the calibration.

- It has not yet been possible to propose ITVs for the term $\mathrm{u}(\mathrm{s})$ applicable to sampling, except in a few cases, where this parameter was found to be actually measurable. It should also be noted that random sanpling errors were frequently not assessed on the basis of experimental data (due to lack of such) and are based on expert opinion and facility experience.

- The combination of the $u(r)$ and $u(s)$ parameters

$$
u_{c}(t)=\left(u(r)^{2}+u(s)^{2} J^{1 / 2}\right.
$$

is equivalent to the relative combined standard uncertainty of the measurement, as it is defined in the ISO ${ }^{[12]}$, NIST $^{[13]}$ and EURACHEM ${ }^{[14}$ Guides, when it is applied to the measurement of a single laboratory.

- The ITVs in Tables 2 to 7 apply to situations where the measured quantity is large enough so that the relative uncertainty of the measurement remains essentially constant for the given range of measurements.

- The $u(r)$ and $u(s)$ parameters of bulk measurements, sampling, element concentration and isotope abundance measurements from Tables 2 to 6 must be combined according to equations (18) and (19), in order to obtain the ITVs, $u_{c}(r)$ and $u_{c}(s)$, applicable to analytical data resulting from a given combination of several measurement steps.

$$
n(r)^{2}=\sum_{n} n(r)^{2}
$$


Attachment 1

International Target Values 2000 for Measurement Uncertainties in Safeguarding Nuclear Materials

Page 18 of 48

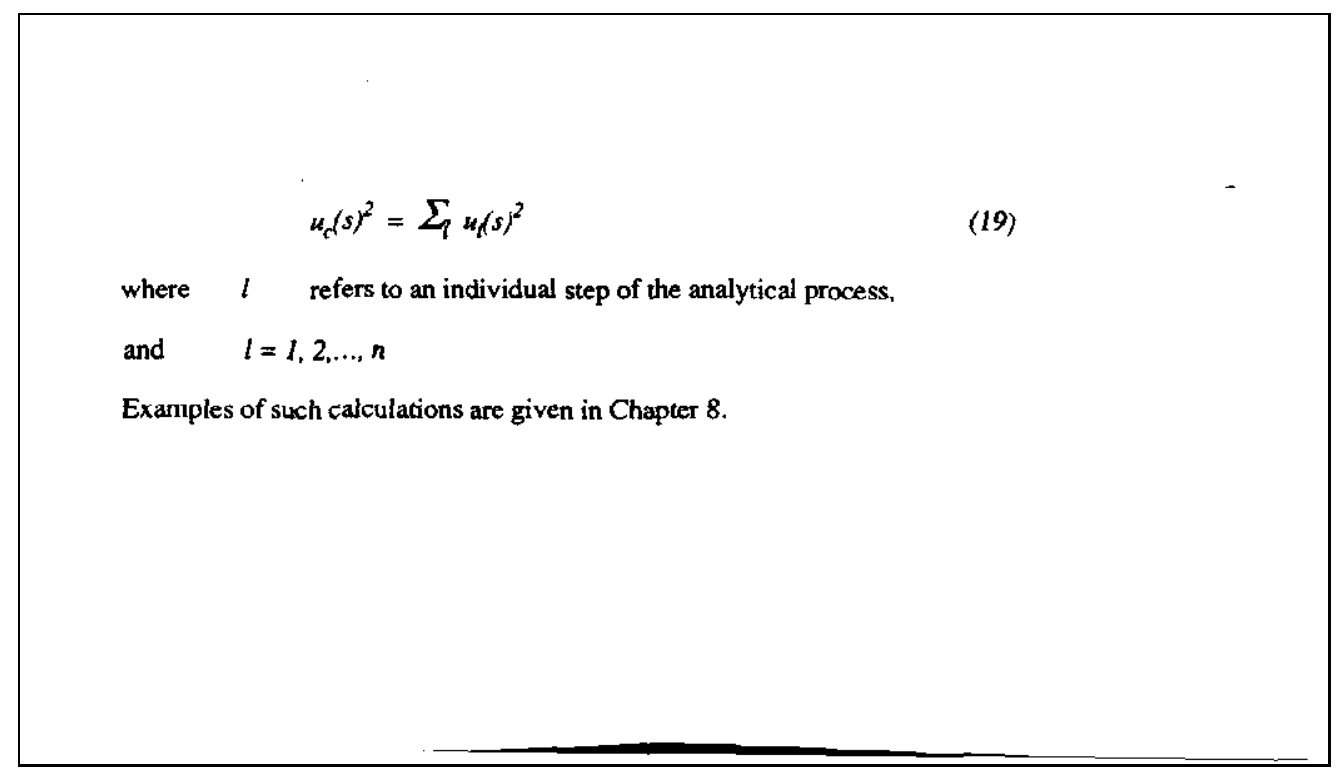




\section{Attachment 1}

International Target Values 2000 for Measurement Uncertainties in Safeguarding Nuclear Materials

Page 19 of 48

\section{Table 1: Measurement Method Codes}

\begin{tabular}{|c|l|}
\hline $\begin{array}{c}\text { Method /nstrumen } \\
\text { Code }\end{array}$ & \\
\hline ANCC & Advanced Neutron Coincidence Counter \\
\hline AWCC & Active Well Coincidence Counter \\
\hline CALR & Calorimeter \\
\hline COMP & $\begin{array}{l}\text { Combined Product Uranium Concentration } \\
\text { and Enrichment Assay (COMPUCEA) }\end{array}$ \\
\hline DIPT & Dip Tube \\
\hline EBAL & Electronic Balance \\
\hline FRSC & Fuel Rod Scanner \\
\hline GRAV & Gravimetry \\
\hline GSMS & Gas Source Mass Spectrometry \\
\hline HKED & Hybrid K-Edge/K-XRF Densitometer \\
\hline HLNC & High Level Neutron Coincidence Counter \\
\hline HRGS & Infield High Resolution Gamma Spectrometer \\
\hline IDMS & Isotope Dilution Mass Spectrometry \\
\hline INVS & Inventory Sample Coincidence Counter \\
\hline KED & K-Edge Densitometer \\
\hline LCBS & Load-Cell Based Weighing System \\
\hline LMCA & Laboratory Multichannel Analyzer/Hi-resolution GS \\
\hline LMCN & Laboratory Multichonnel Analyzer, NaI-detector \\
\hline PCAS & Plutonium Canister Assay System \\
\hline PHON & Photon Neutron Interrogation Device \\
\hline PMCG & Portable Multichannel Analyzer, GeLi-detector \\
\hline PMCN & Portable Multichannel Analyzer, NaI-detector \\
\hline PSMC & PLutonium Scrap Multiplicity Counter \\
\hline TIMS & Thermal lonization Mass Spectrometry \\
\hline TITR & Titration \\
\hline UNCL & Uranium Neutron Coincidence Collar \\
\hline WTDM & Vibrating Tube Bensity Meter \\
\hline & Waste Drum Assay System \\
\hline
\end{tabular}

Note: Measurement codes for NDA instruments correspond to the codes adopted in the IAEA Safeguards Manual ${ }^{[9]]}$ 


\section{Attachment 1}

International Target Values 2000 for Measurement Uncertainties in Safeguarding Nuclear Materials

Page 20 of 48

Table 2: Bulk \& Density Measurements

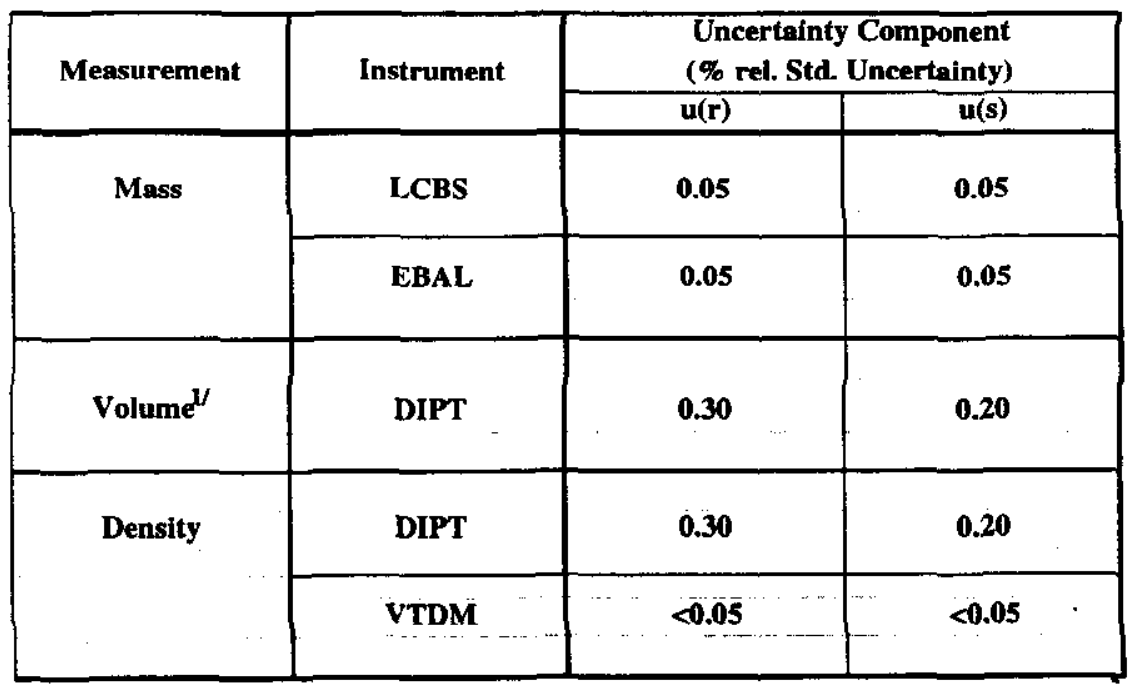

1.) Volume determinations are made on the basis of level pressure, density and temperature measurements. The volume measurement uncertainties are highly dependent on the homogeneity of the liquid, the quality of the density measurements and of the calibration equation determined in the calibration process. The volume measurements may also involve an absolute error component which has to be taken into consideration when determining the overall uncertainty of volume measurements. For accountability tanks in large-throughput facilities, uncertainties of $0.05 \%$ for $u(r)$ and $0.1 \%$ for u(s) at full volume are achievable if: i.) A carefully designed calibration procedure has been implernented under well-controlled environmental and stable temperature conditions; and ii.) Measurements are performed on a well-characterized and homogenized liquid. 


\section{Attachment 1}

International Target Values 2000 for Measurement Uncertainties in Safeguarding Nuclear Materials

Page 21 of 48

\section{Table 3: Sampling Uncerrainties for Elemental Concentration and ${ }^{235} \mathrm{U}$ Abundance}

\begin{tabular}{|c|c|c|c|c|c|}
\hline \multirow[t]{3}{*}{ Material } & \multicolumn{4}{|c|}{$\begin{array}{l}\text { Uncertainty Component } \\
\text { (\% rel. Std. Uncertainty) } \\
\end{array}$} & \multirow{3}{*}{$\begin{array}{l}\text { Recommended } \\
\text { Minimum } \\
\text { Sample } \\
\text { Size }^{\mathrm{y}}\end{array}$} \\
\hline & \multicolumn{2}{|c|}{ Concentration } & \multicolumn{2}{|c|}{${ }^{233} \mathrm{U}$ Abundance } & \\
\hline & $u(r)$ & $\mathbf{u}(\mathbf{s})^{\bar{v}}$ & $\mathbf{u}(\mathbf{F})$ & $\mathbf{u}(\mathbf{s})^{1 /}$ & \\
\hline DUF $_{6}$ & 0.10 & nd & 1 & nd & $5.10 \mathrm{~g}$ \\
\hline $\mathrm{HEUF}_{6} \& \mathrm{LEUF}_{6} \& \mathrm{NUF}_{6}$ & 0.05 & nd & 0.10 & nd & $5.10 \mathrm{~g}$ \\
\hline U-oxide Powder & 0.20 & nd & nd & nd & $10-20 \mathrm{~g}$ \\
\hline U-oxide Pellets & $<0.05^{2 r}$ & $<0.05$ & $<0.05$ & $<0.05$ & 1 pelhet \\
\hline U Scrap (clean) ${ }^{3}$ & 1 & nd & 1 & nd & $30 \mathrm{~g}$ \\
\hline U Serap (dirty) & 10 & nd & 10 & nd & $2 \times 30 \mathrm{~g}$ \\
\hline Reprocessing Input Sol. & 0.30 & 0.20 & $<0.05$ & nd & $2 \times 1 \mathrm{ml}$ \\
\hline U Nitrate Sol. & 0.10 & nd & $<0.05$ & nd & $10 \mathrm{ml} \cdot$ \\
\hline P1, U/Pu Nitrate Sol. & 0.20 & nd & $<0.05$ & nd & $10 \mathrm{ml}$ \\
\hline Pu-oxide & 0.10 & nd & & & $2 \times 1 \mathrm{~g}$ \\
\hline FBR \& LWR MOX & $\begin{array}{l}0.70(\mathbf{P u}) \\
0.20(\overline{\mathrm{U}}) \\
\end{array}$ & nd & 0.10 & nd & 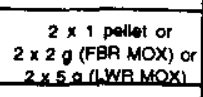 \\
\hline MOX Serap(clean) & 1 & nd & 1 & nd & $2 \times 5 g$ \\
\hline MOX Scrap(dirty) & 10 & nd & 10 & nd & $2 \times 10 \mathrm{~g}$ \\
\hline U Metal & 0.05 & nd & $<0.05$ & nd & 1.58 \\
\hline HEU Alloys & 0.20 & nd & $<0.05$ & nd & $5-10 \mathrm{~g}$ \\
\hline
\end{tabular}

1.) Missing values (nd) have not yet been defined.

2.) 0.20 for Gadolinium-containing pellets.

3.) Scrap with low impurity content and suitable for direct recycling.

4.) Sampling errors can vary widely depending on material heterogeneity and sample size.

5.) According to STR- $69^{[100 \mid}$ 


\section{Attachment 1}

International Target Values 2000 for Measurement Uncertainties in Safeguarding Nuclear Materials

Page 22 of 48

Table 4: Element Concentration

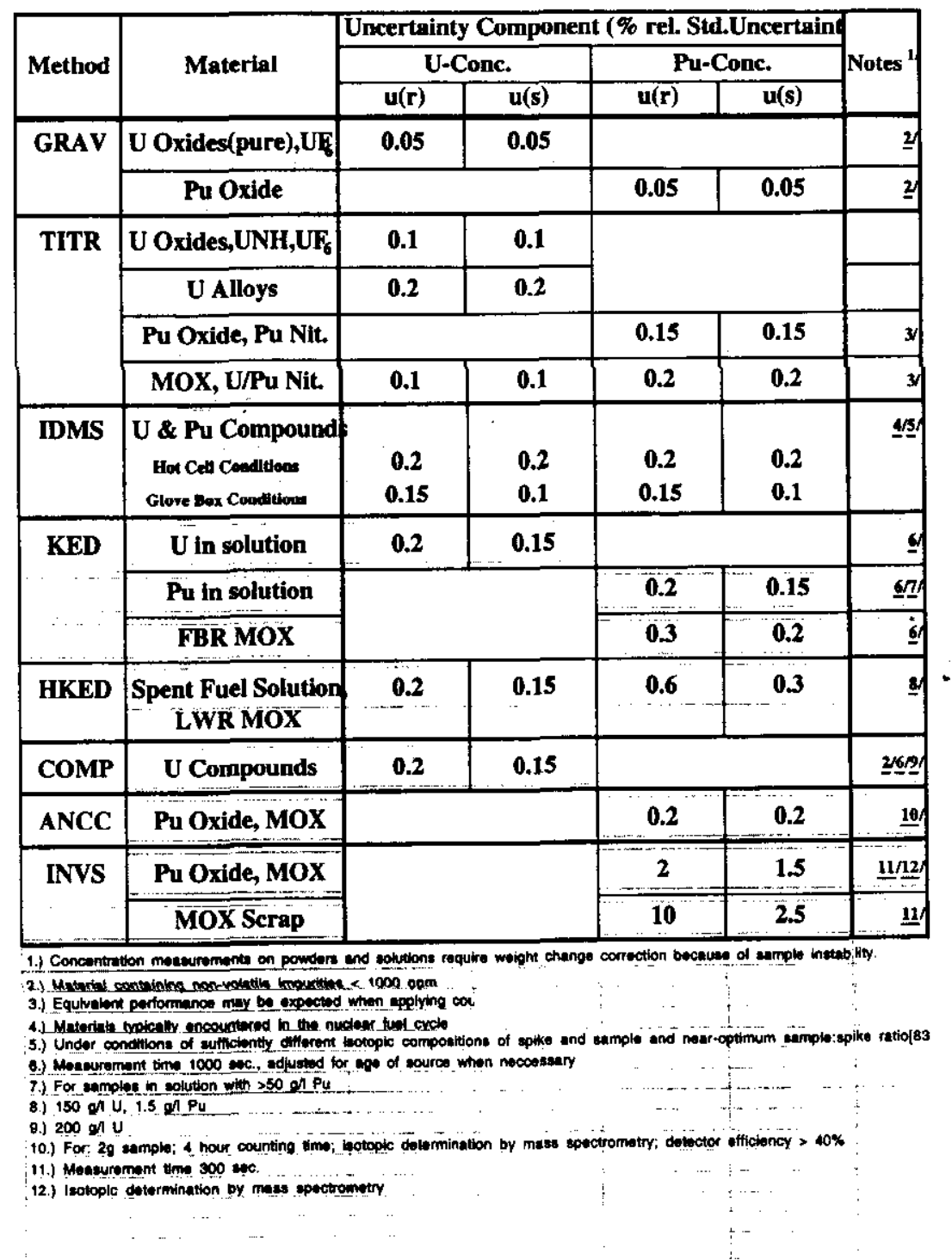


Attachment 1

International Target Values 2000 for Measurement Uncertainties in Safeguarding Nuclear Materials

Page 23 of 48

Table 5: ${ }^{235} \mathrm{U}$ Abundance

\begin{tabular}{|c|c|c|c|c|}
\hline \multirow[t]{2}{*}{ Method } & \multirow[t]{2}{*}{ Material } & \multicolumn{2}{|c|}{$\begin{array}{l}\text { Uncertainty Component } \\
\text { ( } \% \text { rel. Std. Uncertainty) }\end{array}$} & \multirow[t]{2}{*}{ Notes } \\
\hline & & $\mathbf{u}(\mathbf{r})$ & $\mathbf{u}(\mathbf{s})$ & \\
\hline \multirow{3}{*}{ GSMS } & DUF, \& NUF, & 0.1 & 0.1 & \\
\hline & LEUE & 0.05 & 0.05 & \\
\hline & HEUT $_{6}$ & 0.02 & 0.02 & \\
\hline \multirow{4}{*}{ TIMS } & $D U\left(<0.3 w t .5{ }^{2 S} U\right)$ & 0.5 & 0.5 & \\
\hline & $U(0.3 \%<23<1 \%)$ & 0.2 & 0.2 & \\
\hline & $\operatorname{LEU}\left(1 \%<<^{213} U<20 \%\right)$ & 0.1 & 0.1 & \\
\hline & HEU $\left(>20 w t x^{206} U\right)$ & 0.05 & 0.05 & \\
\hline COMP & LEU Compoumds & 0.4 & 0.2 & $\underline{1}$ \\
\hline \multirow{2}{*}{$\mathrm{MMCN}^{2}$} & LEU Ondder & 0.3 & i.3 & \\
\hline & FEt Orides & 0.2 & 0.2 & \\
\hline \multirow{11}{*}{$\operatorname{PMCN}^{2 / Y}$} & DUF $_{6}$ & 20 & 15 & 4 \\
\hline & NUF & 10 & 8 & 9 \\
\hline & LEUF & 5 & 3 & 4 \\
\hline & Nu Oxdes & 5 & 5 & \\
\hline & LEU Oxdes & 3 & 2 & \\
\hline & NU a LEU Serap (dean) & 3 & 5 & $\underline{6}$ \\
\hline & NU a LEU Scrap (dirty) & 15 & 10 & 9 \\
\hline & LEU Fuel Rods & 2.5 & 1 & \\
\hline & LEU Fuel Arsemblies & 2.5 & 1 & \\
\hline & HEU Metel. & 0.5 & 0.5 & $\underline{7}$ \\
\hline & HEU Alloys & 1 & 1 & $\underline{7}$ \\
\hline \multirow{6}{*}{ PMCG } & DUF: & 15 & 10 & 4 \\
\hline & NUF、 & 8 & 5 & 4 \\
\hline & LEUR & 4 & 2 & 4 \\
\hline & LEU Oxldes & 3 & 2 & \\
\hline & HEU Metal & 0.5 & 0.5 & $\underline{7}$ \\
\hline & HEU Alkoys & 1 & 1 & 7 \\
\hline
\end{tabular}

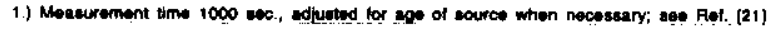

2.) For matorials not containing mprocoused uranium.

3.) Moasurement tirn $300 \mathrm{sec}$.

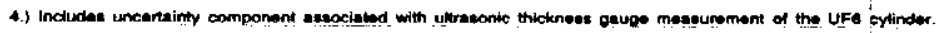

5.) Scrap with low Imourity content and sultable for alrect recyethng

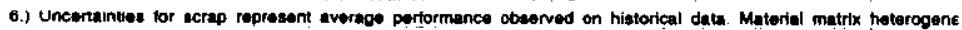
contributor to the oboervod uncertainties and can vary widery.

7.) Calibration againat referemes maturial certifled to $0.3 \%$ or better 4 uncertaintips in the correction of containi absorption of $0.5 \%$ or lose 
Attachment 1

International Target Values 2000 for Measurement Uncertainties in Safeguarding Nuclear Materials

Page 24 of 48

\section{Table 6: Plutonium Isotope Assay of Pu Oxide and MOX \\ (\% Relative Standard Uncertainties)}

\begin{tabular}{|c|c|c|c|c|c|c|c|c|}
\hline \multirow{3}{*}{$\begin{array}{c}\text { Material } \\
\text { Type }\end{array}$} & \multirow{3}{*}{$\begin{array}{c}\text { Isotope } \\
\text { Ratio }\end{array}$} & \multirow{3}{*}{$\begin{array}{c}\text { Typical } \\
\text { Value for } \\
\text { Ratio (*100) }\end{array}$} & \multicolumn{6}{|c|}{ Method } \\
\hline & & & \multicolumn{2}{|c|}{ TIMS $^{1 /}$} & \multicolumn{2}{|c|}{ HRGS $^{2}$} & \multicolumn{2}{|c|}{$\mathrm{LMCA}^{\mathrm{y}}$} \\
\hline & & & $\mathbf{u ( r )}$ & $\mathbf{u}(\mathbf{s})$ & $u(r)$ & $u(s)$ & $u(r)$ & $u(s)$ \\
\hline \multirow{4}{*}{$\begin{array}{c}\text { High- } \\
\text { Burnup } \\
\text { Pu }\end{array}$} & ${ }^{238} \mathrm{Pu}{ }^{239} \mathrm{Pu}$ & 1.7 & 1.5 & 1 & 2 & 2 & 1 & 1 \\
\hline & ${ }^{240} \mathrm{Pu}{ }^{239} \mathrm{Pu}$ & 43 & 0.1 & 0.05 & 1 & 1 & 0.7 & 0.7 \\
\hline & ${ }^{241} \mathrm{Pu}{ }^{239} \mathrm{Pu}$ & 13 & 0.2 & 0.2 & 1 & 1 & 0.7 & 0.7 \\
\hline & ${ }^{242} \mathrm{Pu}{ }^{234} \mathrm{Pu}$ & 8 & 0.2 & 0.3 & & & & \\
\hline \multirow{4}{*}{$\begin{array}{l}\text { Low- } \\
\text { Burnup }\end{array}$} & ${ }^{238} \mathrm{Pu}{ }^{239} \mathrm{Pu}$ & 0.02 & 10 & 10 & 10 & 10 & 5 & 5 \\
\hline & ${ }^{240} \mathrm{Pu} /{ }^{239} \mathrm{Pu}$ & 6 & 0.15 & 0.1 & 2 & 2 & 1.5 & 1.5 \\
\hline & ${ }^{241} \mathrm{Pu} \mathrm{P}^{239} \mathrm{Pu}$ & 0.2 & $\mathbf{1}$ & 1 & 2 & 2 & $\mathbf{I}$ & 1 \\
\hline & ${ }^{242} \mathrm{Pu}{ }^{239} \mathrm{Pu}$ & 0.05 & 2 & 2 & & & & \\
\hline
\end{tabular}

1.) ${ }^{238} \mathrm{Pu} /{ }^{239} \mathrm{Pu}$ by alpha spectTIMS combination

2.) Measurement time $3 \times 100 \mathrm{sec}$.

3.) Messurement time $3 \times 1000$ sec; $0.5 \mathrm{~g} \mathrm{P}$ 


\section{Attachment 1}

International Target Values 2000 for Measurement Uncertainties in Safeguarding Nuclear Materials

Page 25 of 48

Table 7: Total Mass - ${ }^{235} \mathrm{U} \&$ Pu

by Direct NDA Measurement Techniques

\begin{tabular}{|c|c|c|c|c|c|c|}
\hline \multirow{3}{*}{ Instrumen } & \multirow{3}{*}{ Mnterial } & \multicolumn{4}{|c|}{ Uncertainty Component (\% rel.Std.Dev.) } & \multirow{3}{*}{ Notes } \\
\hline & & \multicolumn{2}{|c|}{${ }^{235} \mathrm{U}$ Mass } & \multicolumn{2}{|c|}{ Pu Mass } & \\
\hline & & $u(\mathbf{r})$ & $u(s)$ & $\mathbf{u ( x )}$ & $\mathbf{u ( s )}$ & \\
\hline \multirow[t]{2}{*}{ AwCC } & HEU Metal, HEU Allog & 5 & $\mathbf{3}$ & & & $\underline{1}$ \\
\hline & HEU Fuel Elements & 3 & 2 & & & $\underline{1}$ \\
\hline FRSC & U Fuel Rods & 1 & 1 & & & \\
\hline \multirow[t]{2}{*}{ PHON } & LEU Oxides & 2 & 1 & & & \\
\hline & LEU Scrap & 4 & 1 & & & \\
\hline UNCL & U Fuel Assembilex & 4 & 2 & & & \\
\hline \multirow[t]{7}{*}{ HLNC } & Pu Oxide Powder & & & $I$ & 0.5 & 231 \\
\hline & FBR MOX $(>10 \% \mathrm{Fu})$ & & & 2 & 0.5 & $\underline{23}$ \\
\hline & LWR MOX (< $10 \%$ Pu) & & & 4 & 1.5 & 29 \\
\hline & MOX Serap & & & 10 & 3 & 244 \\
\hline & Pu Fuei Rods & & & 15. & I & 291 \\
\hline & MOX Fuet Rods & & & 2 & 1 & $2 / 3$ \\
\hline & MOX Fuel Assemblies & & & 1.5 & 1 & 221 \\
\hline \multirow[t]{2}{*}{ PCAS } & Farmox & & & 15 & 1 & 3 \\
\hline & Mox Scrap & & & 8 & 2 & 4 \\
\hline \multirow[t]{2}{*}{ PSMC } & MOX Scrap (dean) & & & 25 & 1 & s.s. \\
\hline & MOX Scrap (dirty) & & & 8 & 2 & 4 \\
\hline WDAS & Mox Waste & & & 8 & 2 & 4 \\
\hline CALR & Pu Oxde and MOX & & & 0.4 & 0.4 & $36 \pi$ \\
\hline
\end{tabular}

1.) Measurentent time $600 \mathrm{sec}$.

2.) Measurement time $3 \overline{0} \overline{\mathrm{sec}}$.

3.) Isotopic deterrination by mass spectrometry and alpha spectrometry.

4.) Uncentainties for scrap represedt average performance observed on hiswrical data. Material marrix beterogeneity is

the main contributor to the observed uncerainties and can vary widely.

5.) Scrap with low impurity content and suitsble for direct recycling

6.) ${ }^{2+1}$ Am content determived by gamma spectrometry or alpha spectrontiry

7.) Lower uncertainties art achievable for materials containing low burn up Pu 


\section{Attachment 1}

\section{International Target Values 2000 for Measurement Uncertainties in Safeguarding Nuclear Materials \\ Page 26 of 48}

\section{Use of ITVs}

ITVs are considered to be achievable in routine measurements involved in the determination of the amount of nuclear materials for materials accountancy and safeguards verification purposes. They are intended to be used as a reference by plant operators, state systems and international safeguards organizations. They should, however, not be normally used in place of values based on actual measurements in estimating the statistical significance of operator-inspector differences or MUF. Analytical laboratories can find it useful to determine experimentally the actual uncertainties of their measurements, and to compare them with the corresponding values, which can be derived from the ITVs 2000

Safeguards authorities regularly compare the performance values with the current ITVs. They will examine with the relevant authorities and laboratories means of improving the performance, in cases where the performance values are significantly higher than the ITVs, and too high to allow the LAEA to meet its detection goals ${ }^{\text {[101! }}$. When reliable performance values are not available. ITVs may be used instead to calculate sampling plans, to set reject limits and to calculate estimates of the combined uncertainties of inventories, throughputs, MUF and D's, as described in Annex 2.

Such applications of the ITVs require having a good insight of the measurement and verification systems. It is in particular important to recognize that, because of practical constraints, some measurement steps may be common to the operator and the inspector. It should also not be forgotten that the operator-inspector differences can carry errors which are not related to measurement uncertainties.

The following three examples illustrate how the tabulated ITVs can be used to calculate ITVs for combined uncertainties applicable to practical situations. Further examples are presented in Reference [102]. 


\section{Attachment 1}

\section{International Target Values 2000 for Measurement Uncertainties in Safeguarding Nuclear Materials} Page 27 of 48

\section{Example 1:}

\section{Target Values for the Determination of the Total Mass of Fissile Element on Independent Samples}

Consider a situation where the operator and the inspector determine fully independently the total antount of plutonium in a batch of LWR pellets. The operator measures the plutonium concentration by titration on ten randomly selected pellets, the inspector by IDMS on an independently selected but single pellet.

The Target Values for the combined relative standard uncertainties applicable to the detemination of the total mass of plutonium by the operator are derived from the following equations, respectively for the random errors, the errors of systematic character and their combination:

$$
\begin{aligned}
& u_{c}(r, O)=\sqrt{\left[\sum_{i} u_{i}^{2}(r, O) / n_{i}(O)\right]} \\
& u_{c}(s, O)=\sqrt{\left[\sum_{i} u_{i}^{2}(s, O)\right]} \\
& u_{c}(O)=\sqrt{\left[u_{c}^{i}(r, O)+u_{c}^{2}(s, O)\right]}=\sqrt{(0.0555+0.0425)}=0.31 \%
\end{aligned}
$$

The above values would be used in the calculation of Target Values for the relative standard uncertainties to be expected in the inventory, throughput and MUF declared by the operator.

Similar equations are used to calculate the corresponding values applicable to inspector's measurements, $u_{c}(r, I), u_{c}(s, I)$ and $u_{c}(\mathrm{I})$. The Target Value for the combined uncertainties on the total Pu mass measured by the inspector is equal to:

$$
u_{c}(I)=\sqrt{\left[u_{c}^{2}(r, l)+u_{c}^{2}(s, I)\right]}=\sqrt{(0.5150+0.0125)}=0.73 \%
$$

Its magnitude is determined essentially by the random sampling uncertainty component. This is also true for the Target Value applicable to the Operator-Inspector difference:

$$
\left.u_{d}=\sqrt{\left[u_{d}^{2}(r)+u_{d}^{2}(s)\right.}\right]=\sqrt{(0.5705+0.0550)}=0.79 \%
$$

Assuming that the values of Target Values, $u_{c}{ }^{\prime}$ 's, given in Table 8 and equations (22) (23) and (24), are effectively achieved, the $95 \%$ confidence intervals of the final results of the operator, of the inspector and of their difference, would be respectively equal to:

$$
\begin{aligned}
& \mathrm{CL}(\mathrm{O})=\mathrm{k} u_{\mathrm{c}}(\mathrm{O})=2 \times 0.31=0.62 \% \\
& \mathrm{CL}(\mathrm{I})=\mathrm{k} u_{\mathrm{c}}(\mathrm{I})=2 \times 0.73=1.46 \% \\
& \mathrm{CL}(\mathrm{d})=\mathrm{k} u_{\mathrm{c}}(\mathrm{d})=2 \times 0.79=1.58 \%
\end{aligned}
$$

where the coverage factor $k$ is 2 . 
Attachment 1

International Target Values 2000 for Measurement Uncertainties in Safeguarding Nuclear Materials

Page 28 of 48

Table 8: Target Values for Total Pu Mass

with Independent Samples and DA (Example 1)

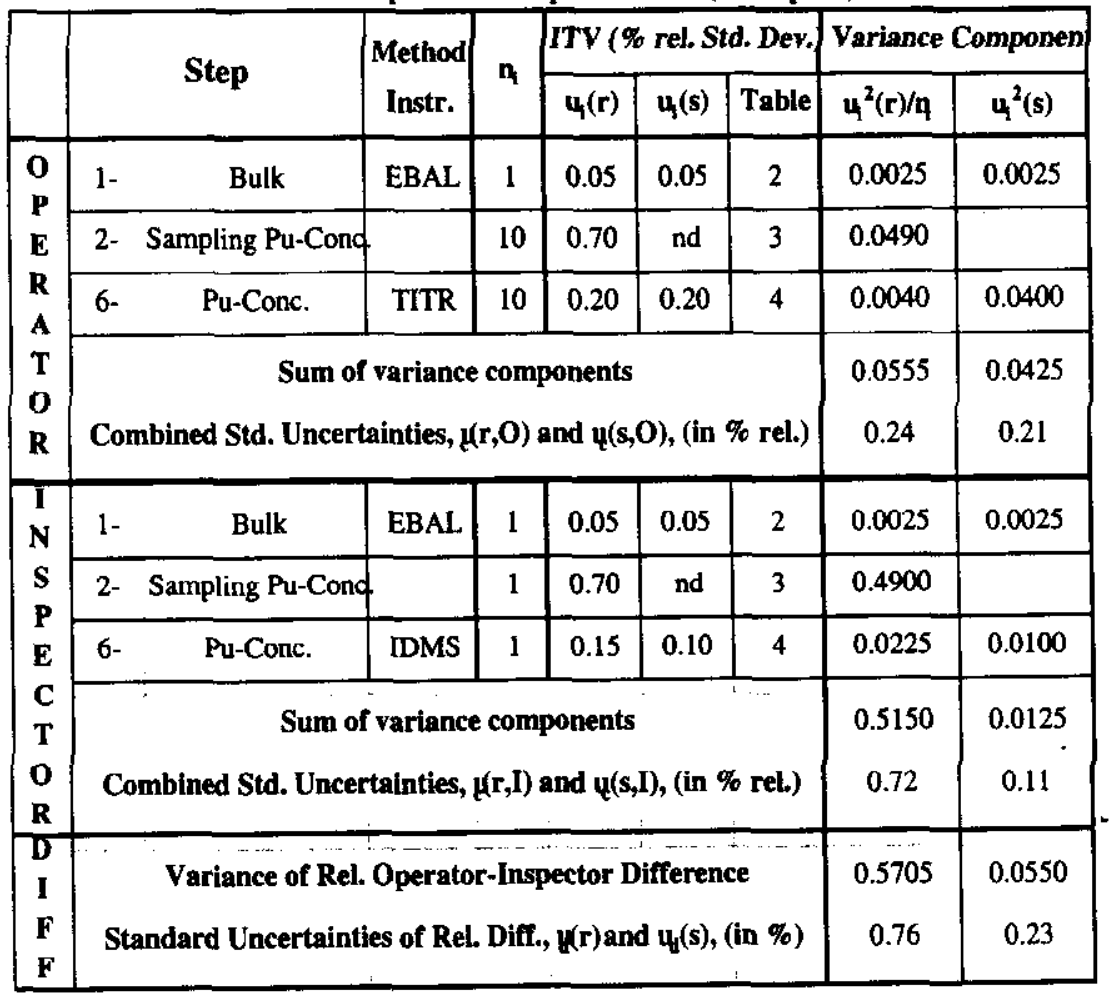




\section{Attachment 1}

\section{International Target Values 2000 for Measurement Uncertainties in Safeguarding Nuclear Materials} Page 29 of 48

\section{Example 2:}

Target Values for the Determination of the Total Mass of Fissile Element on a Common Sample.

In situations where the inspector analyzes a subsample of a homogeneous operator's sample, the sampling errors no longer contribute to the uncertainty of the Operator-Inspector difference. An example of this situation could be a co-operative effort to identify the existance of biases in the chemical analysis.

Apply these conditions to the first example. In this case, as shown in Table 9, the Target Value for the Operator-Inspector difference and its $95 \%$ confidence interval will be:

$$
\begin{aligned}
& u_{d}=\sqrt{(0.0675+0.0550)}=0.35 \% \\
& C L(d)=k u_{d}=2 \times 0.35=0.70 \%
\end{aligned}
$$

Table 9: Target Values for Operator-Inspector Difference on Total Pu Mass, with Common Sample and DA (Example 2)

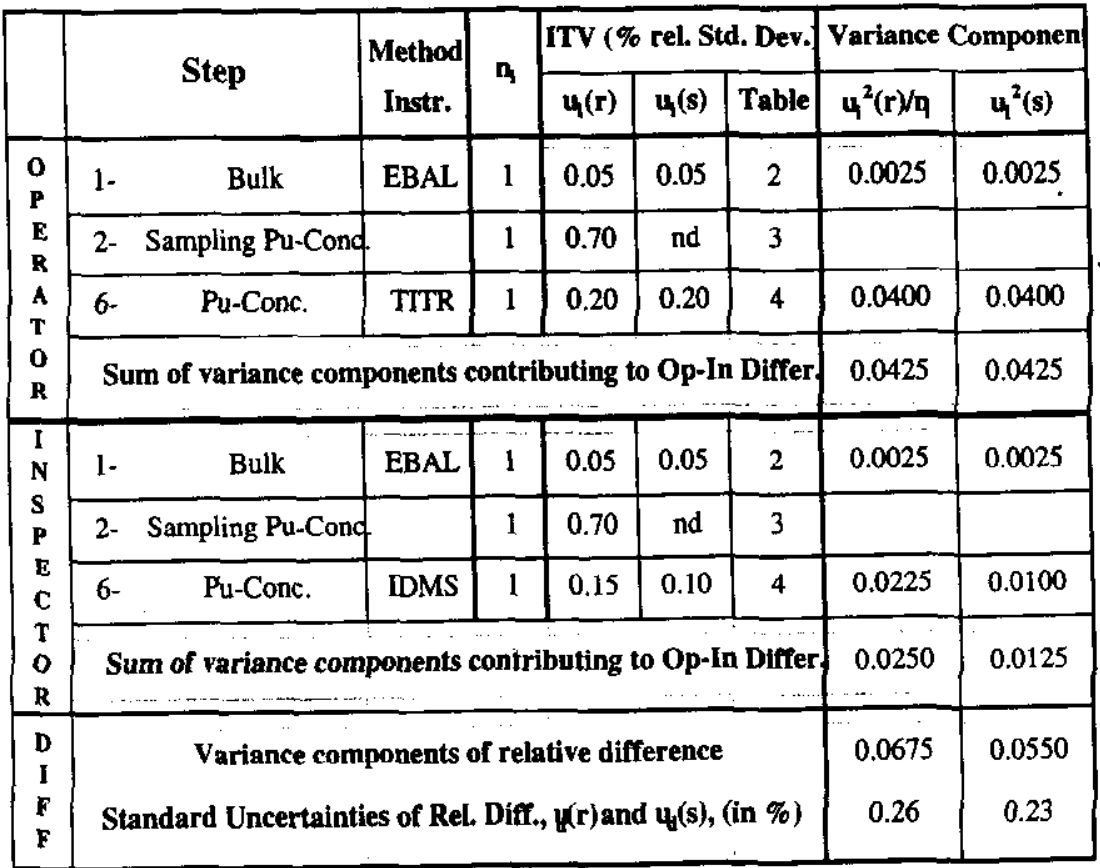




\section{Attachment 1}

\section{International Target Values 2000 for Measurement Uncertainties in Safeguarding Nuclear Materials \\ Page 30 of 48}

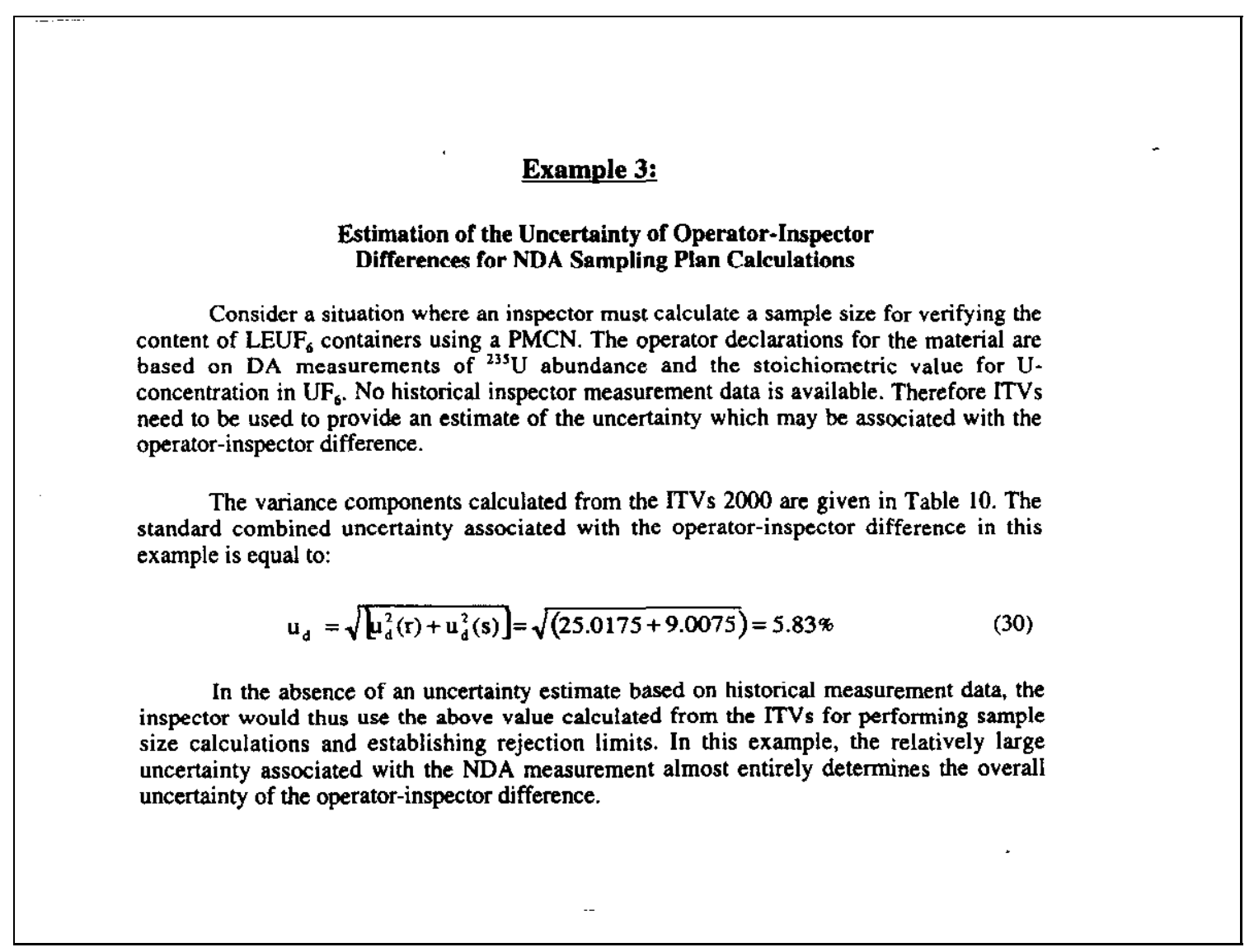


Attachment 1

International Target Values 2000 for Measurement Uncertainties in Safeguarding Nuclear Materials

Page 31 of 48

Table 10: Target Values for Operator-Inspector difference

(Example 3)

\begin{tabular}{|c|c|c|c|c|c|c|c|}
\hline & \multirow{2}{*}{ Step } & \multirow{2}{*}{ Method/Instr } & \multicolumn{3}{|c|}{ ITV (\% rel. Std. Dev.) } & \multicolumn{2}{|c|}{ Variance Componen } \\
\hline & & & $\mathbf{u}(\mathbf{r})$ & $4(s)$ & Table & $\mathbf{u}_{1}^{2}(\mathbf{r})$ & $4^{2}(s)$ \\
\hline \multirow{5}{*}{$\begin{array}{l}\mathbf{O} \\
\mathbf{P} \\
\mathbf{E} \\
\mathbf{R} \\
\mathbf{A} \\
\mathbf{T} \\
\mathbf{O} \\
\mathbf{R}\end{array}$} & Bulk & EBAL & 0.05 & 0.05 & 2 & 0.0025 & 0.0025 \\
\hline & 2- Sampling ${ }^{235} \mathrm{U}$ wt. $\%$ & & 0.1 & & 3 & 0.0100 & \\
\hline & U-Conc. & Stoichiom. Va & & & & & \\
\hline & ${ }^{235} \mathrm{U} w \mathrm{t} . \%$ & GSMS & 0.05 & 0.05 & 5 & 0.0025 & 0.0025 \\
\hline & \multicolumn{5}{|c|}{ Sum of variance components } & 0.0150 & 0.0050 \\
\hline \multirow{4}{*}{$\begin{array}{l}I \\
\mathrm{I} \\
\mathrm{S} \\
\mathrm{P} \\
\mathrm{E} \\
\mathrm{C} \\
\mathrm{T} \\
\mathrm{O} \\
\mathrm{R}\end{array}$} & Bulk & EBAL & 0.05 & 0.05 & 2 & 0.0025 & 0.0025 \\
\hline & U-Conc. & Stoichiom. Val & & & & & \\
\hline & ${ }^{235} \mathrm{U}$ wt. $\%$ & PMCN & 5 & 3 & 5 & 25.0000 & 9.0000 \\
\hline & \multicolumn{5}{|c|}{ Sum of variance components } & 25.0025 & 9.0025 \\
\hline $\begin{array}{l}\mathbf{D} \\
\mathbf{I} \\
\mathbf{F} \\
\mathbf{F}\end{array}$ & \multicolumn{5}{|c|}{ Variance components of relative difference } & $\begin{array}{c}25.0175 \\
5.00\end{array}$ & $\begin{array}{c}9.0075 \\
3.00\end{array}$ \\
\hline
\end{tabular}




\section{Attachment 1}

\section{International Target Values 2000 for Measurement Uncertainties in Safeguarding Nuclear Materials Page 32 of 48}

\section{Future Developments}

It is intended to keep updating the ITV tables regularly in order to incorporate the latest relevant information. The following activities will be especially important for this purpose:

- Growing emphasis is being placed on reassessing the uncertainties of chemical measurements according to the ISO ${ }^{\mid 21]}$, NIST ${ }^{|3|}$ and EURACHEM ${ }^{[14 \mid}$ guides. This should be done systematically for the methods in current use. It should become a part of the process of qualification of new measurement methods and instrumentation.

- The inspectorates will continue to update actual performance evaluations.

- It is important that interlaboratory measurement evaluation programmes continue to be conducted, particularly in the area of Pu measurements. Operator and inspector laboratories should participate in such programmes. Their results should be published as it was done in the past.

- Models more specific to the NDA measurement processes are being reviewed by the ESARDA/NDA Working Group to monitor and assess the sources of major uncertainties in actual inspectors' measurements. This will hopefully involve uncertainty assessments in line with the above guides as well as periodical estimates of actual Performance Values and the development of interlaboratory measurement evaluation programmes for NDA.

- Results of experimental qualifications of recommended sampling procedures ${ }^{[193-1 / 2]}$ should be made available to the inspectorates to substantiate and expand ITVs for the uncertainty components in sampling procedures.

- The IAEA will also follow with the greatest interest developments in bulk measurements and elemental assays of spent fuel solutions and their impact on the accuracy of the accountability of large throughputs and inventories of nuclear materials at large plants now coming under safeguards.

The IAEA will continue its cooperation on the above topics with Euratom, with State authorities and with the expert groups, which were involved in the review of the ITVs 2000 . The next revision of the ITV $s$ will also be another opportunity to seek further contributions from more countries and organizations. 


\section{Attachment 1}

\section{International Target Values 2000 for Measurement Uncertainties in Safeguarding Nuclear Materials}

Page 33 of 48

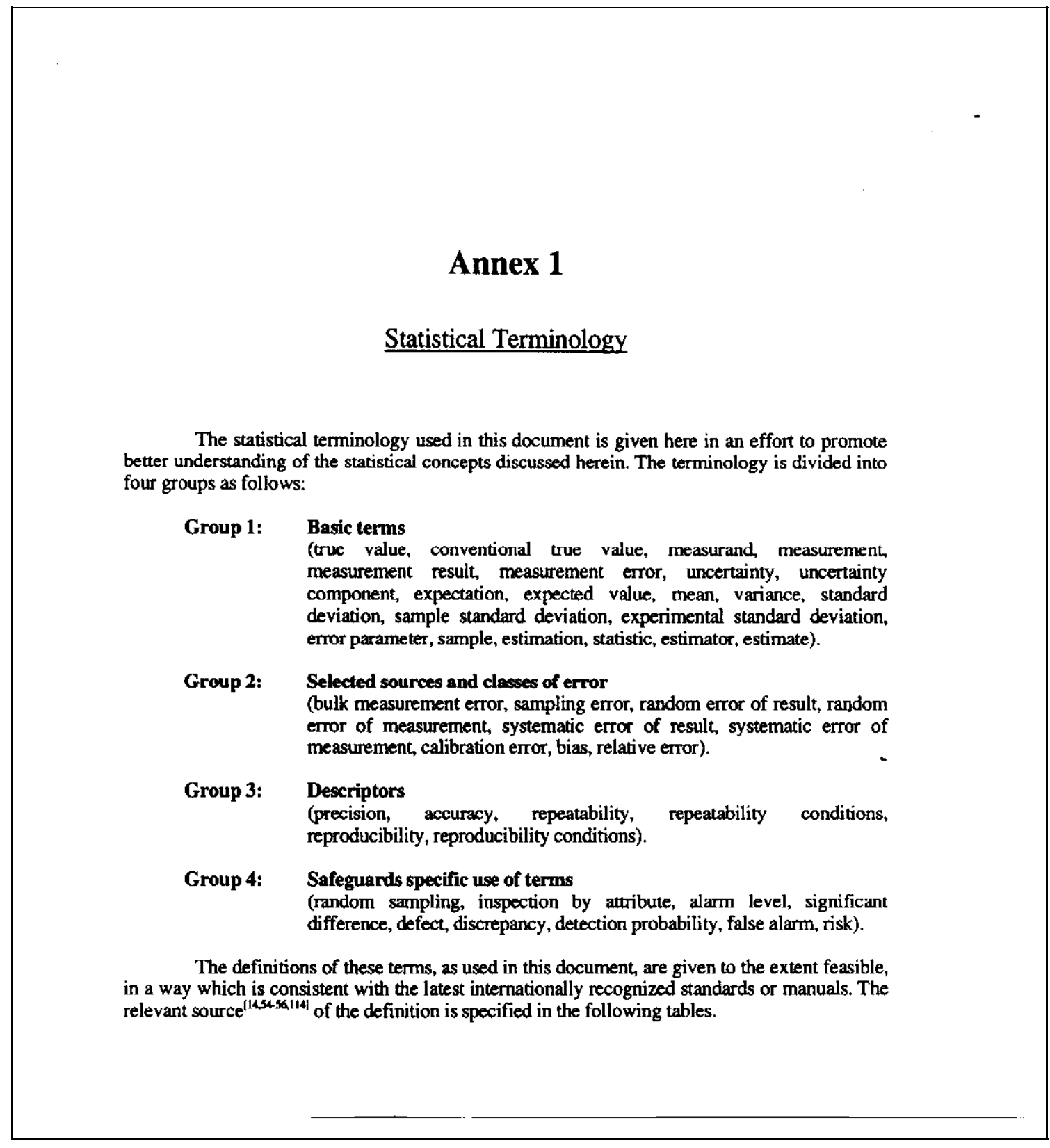




\section{Attachment 1}

\section{International Target Values 2000 for Measurement Uncertainties in Safeguarding Nuclear Materials}

\section{Page 34 of 48}

\begin{tabular}{|c|c|c|}
\hline \multicolumn{3}{|c|}{ GROUP 1: BASIC TERMS } \\
\hline Terta & Definition & Ret. \\
\hline true value & $\begin{array}{l}\text { Value consistent with the defiaition of a given particular quantity. } \\
\text { NOTES: } \\
\text { 1. This is a value that would be obtained by a perfect measurement. } \\
\text { 2. True values are by nature indeterminate. }\end{array}$ & $\begin{array}{l}55] \\
1.19\end{array}$ \\
\hline $\begin{array}{l}\text { conventional true } \\
\text { value }\end{array}$ & $\begin{array}{l}\text { Value attributed to a particular quantity and accepted, sometimes by convention, as } \\
\text { having an theertainty appropriate for a given purpose. } \\
\text { NOTE: } \\
\text { "Conventional tove value" is sometimes called assigned value, best estimate of the value. } \\
\text { conventional value, or reference value. }\end{array}$ & $\begin{array}{l}{[55]} \\
1.20\end{array}$ \\
\hline measurand & Particular quantity subject io measurement. & $\begin{array}{l}{[55]} \\
2.6\end{array}$ \\
\hline measurement & Set of cperations having the object of determining a value of a quantity. & $\begin{array}{c}{[55]} \\
2.1 \\
\end{array}$ \\
\hline $\begin{array}{l}\text { measurement } \\
\text { result }\end{array}$ & $\begin{array}{l}\text { Value attibuted to a measurand obtainod by measurement } \\
\text { NOTES: } \\
\text { 1. When the verin "result of a measurement" is used, it should be made clear whether } \\
\text { it refers w: } \\
\text { - the value indicated by the measurement ins trument } \\
\text { - the uncorrected result } \\
\text { - the crmected result } \\
\text { and whethet several values are averaged. } \\
\text { 2. A complete statement of the result of a measurement includes information about } \\
\text { the uncertainty of measurement. }\end{array}$ & $\begin{array}{c}55] \\
3.1\end{array}$ \\
\hline $\begin{array}{l}\text { measurement } \\
\text { error }\end{array}$ & $\begin{array}{l}\text { Result of a measurement minus a true value of the measurand. } \\
\text { NOTES: } \\
\text { 1. Since a true value cannot be determined, in practice a conventional tue value is } \\
\text { used. } \\
\text { 2. The quantity is sometimes called absolute error of measurement when it is } \\
\text { necessary to distinguish it from relative error. }\end{array}$ & $\begin{array}{l}{[55]} \\
3.10\end{array}$ \\
\hline $\begin{array}{c}\text { uncertainty } \\
\text { (of messufement) }\end{array}$ & $\begin{array}{l}\text { Parameter associased with the result of a measurement, characterizing the dispersion of } \\
\text { the values that could reasonably be attributed to the measurand } \\
\text { NOTE: } \\
\text { The parameter may be, for example, a standand deviation (in which case the uncertainty is } \\
\text { afso called the standard uncertainty), of the width of a confidence interval. }\end{array}$ & $\begin{array}{c}{[59\}} \\
3.9\end{array}$ \\
\hline $\begin{array}{l}\text { uncertainty } \\
\text { component }\end{array}$ & $\begin{array}{l}\text { Uncertainty arising from a distinct source contributing to the overall uncertainty. } \\
\text { NOTES: } \\
\text { 1. If there is correlation between any components then this has to be taken into } \\
\text { accoumt by determining the covariance. } \\
\text { 2. It is often possible to evaluate the combined effect of several components. } \\
\text { 3. Where cumpunents whose contribution is evaluaned together are correlared, there) } \\
\text { may be no wditional need to make accoumt of the correlation }\end{array}$ & $\begin{array}{l}{[14]} \\
2.3 .1\end{array}$ \\
\hline $\begin{array}{l}\text { expectation, } \\
\text { expected value, } \\
\text { mear }\end{array}$ & $\begin{array}{l}\text { If } X \text { is a continuous random variable having the probability density function } f(x) \text { then } \\
\text { the expectation (or expected value or mean), if it exists, is } \\
\qquad \mu_{x}=E(X)=\int X \cdot f(x) d x \\
\text { (the intepral being extended over the intervals of variation of } X \text { ). }\end{array}$ & $\begin{array}{l}{[54]} \\
1.18\end{array}$ \\
\hline variance & $\begin{array}{l}\qquad \sigma^{2}=\mathrm{V}(\mathrm{X})=\mathrm{E}[\mathrm{X}-\mathrm{E}(\mathrm{X})]^{2} \\
\text { The variance is the expectation of the square of the certred random variable (i.e. a } \\
\text { random variable the expectation of which equats zero). }\end{array}$ & $\begin{array}{l}{[54]} \\
1.22\end{array}$ \\
\hline
\end{tabular}




\section{Attachment 1}

\section{International Target Values 2000 for Measurement Uncertainties in Safeguarding Nuclear Materials}

Page 35 of 48

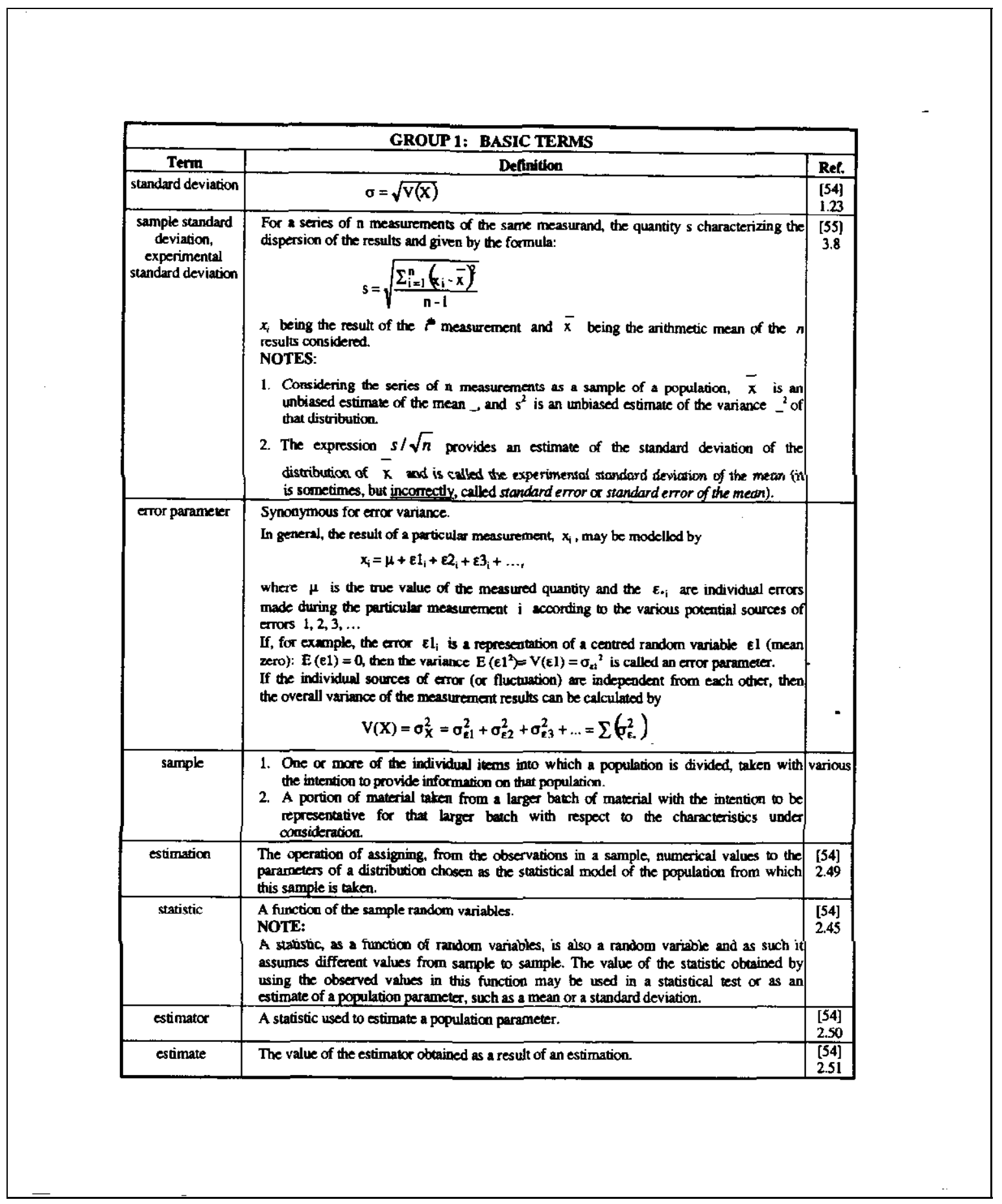




\section{Attachment 1}

\section{International Target Values 2000 for Measurement Uncertainties in Safeguarding Nuclear Materials Page 36 of 48}

\begin{tabular}{|c|c|c|}
\hline \multicolumn{3}{|c|}{ GROUP 2: SELECTED SOURCES and CLASSES of ERRORS } \\
\hline Term & Definition & Ref. \\
\hline $\begin{array}{l}\text { bulk } \\
\text { measurement } \\
\text { error }\end{array}$ & The measured mass (volume) of an itern minus its true mass (volume). & $\begin{array}{l}{[55]} \\
3.10\end{array}$ \\
\hline sampling error & $\begin{array}{l}\text { The true value for the portion of matrial constituting the sample minus the true value for } \\
\text { the larger balch of material for which the sample is intended to be representative. }\end{array}$ & \\
\hline $\begin{array}{l}\text { random error } \\
\text { (of result) }\end{array}$ & $\begin{array}{l}\text { A component of the error, which, antong a number of test resulis for the same } \\
\text { characteristic, varies in an unpredictable way. } \\
\text { NOTE: The random enror of an analytical result canrot be compensand for, but it can be } \\
\text { usually reduced by increasing the number of observations. }\end{array}$ & $\begin{array}{l}{[54]} \\
3.9\end{array}$ \\
\hline $\begin{array}{c}\text { randorn error } \\
\text { (of measurement) }\end{array}$ & $\begin{array}{l}\text { Result of a measurement minus the mean that would result from an infinite number of } \\
\text { measurements of the same meastrand carrich out under repeatability conditions. } \\
\text { NOTE: } \\
\text { 1. Random measurement error is equal to measurement error minus systematic } \\
\text { measurement error. } \\
\text { 2. Because only a finite number of measurements can be made, it is possible to deternine } \\
\text { cnly an estimate of candom error. }\end{array}$ & $\begin{array}{l}{[55]} \\
3.13\end{array}$ \\
\hline $\begin{array}{c}\text { systematic emor } \\
\text { (of result) }\end{array}$ & $\begin{array}{l}\text { A component of the error, which, among a number of test results for the same } \\
\text { characteristic, remains constant or varies in a predictable way. } \\
\text { NOTnS: } \\
\text { 1. Systematic errors and their causes may be lonown or unknown. } \\
\text { 2. Under constant measurement conditions, the systematic error is independent of the } \\
\text { number of measurements turde ind therefore cannot be reduced by increasing the } \\
\text { numaber of analyses. }\end{array}$ & {$[\mathbf{5 4 ]}$} \\
\hline $\begin{array}{l}\text { systematic error } \\
\text { (of measurement) }\end{array}$ & $\begin{array}{l}\text { Mean that would result from an infinite aumber of measurements of the same measurand } \\
\text { carried out umder repeatability conditions minus a true value of the measurand. } \\
\text { NOTES: } \\
\text { 1. It is important to observe the restriction "under repeatability conditions". The value } \\
\text { of the systematic measurement error may remain constant as long as the } \\
\text { measurement conditions remain unaltered. However it may vary, in an } \\
\text { unpredictable manner, with the changing of the measurement conditions or the } \\
\text { settings of the measurement system. The systematic measurement error is therefore } \\
\text { systematic (or constant) only with respect to a given set of measurement results, } \\
\text { while it is at the same time a random component of the ertor on a long term } \\
\text { perspective. Heace the systematic measurement error possesses a probability } \\
\text { distribution (with expectation zero) and can be represented by a random statistical } \\
\text { variable over a sufficiently long period of time. } \\
\text { 2. The systematic emror components under consideration in the present document are } \\
\text { all of this dual nature. }\end{array}$ & $\begin{array}{l}{[55]} \\
3.14\end{array}$ \\
\hline calibration error & $\begin{array}{l}\text { An error associated with a given calibration. Hence, a systematic measurement error } \\
\text { component with respect to all measurements perforned with the same calibration. }\end{array}$ & $\begin{array}{c}{[114]} \\
7.9\end{array}$ \\
\hline bias & $\begin{array}{l}\text { The difference between the expectation of the test result and an accepted reference value } \\
\text { (conventional true value). } \\
\text { NoTt: } \\
\text { 1. Bias can also be described as the total of all long term systematic error components; } \\
\text { i.e., those components of the error that do not vary even under reproducibility } \\
\text { conditions. } \\
\text { 2. Like the true value, bias is by nature indeterminate. } \\
\text { 3. If the bias is estimated and corrtcied fot, the uncertainty of the correction must still } \\
\text { be taker into account. }\end{array}$ & $\begin{array}{l}{[54]} \\
3.13\end{array}$ \\
\hline relative error & $\begin{array}{l}\text { The absolute enor of the measurement divided by the true value of the measurand. } \\
\text { Frequently expressed as a percentage vahe (i.e. multiplied by hundred). }\end{array}$ & \\
\hline
\end{tabular}




\section{Attachment 1}

\section{International Target Values 2000 for Measurement Uncertainties in Safeguarding Nuclear Materials}

Page 37 of 48

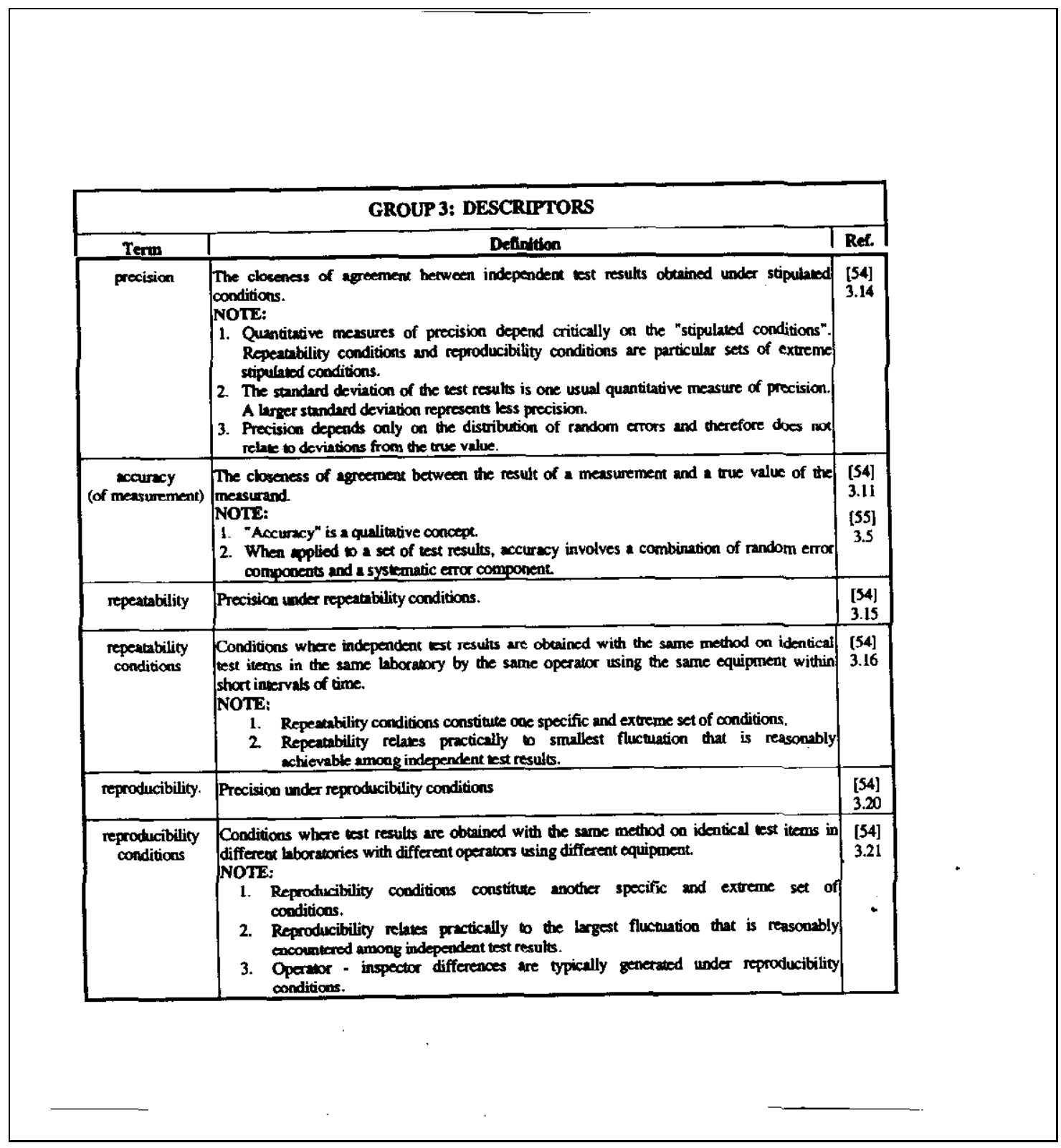




\section{Attachment 1}

\section{International Target Values 2000 for Measurement Uncertainties in Safeguarding Nuclear Materials Page 38 of 48}

\begin{tabular}{|c|c|c|}
\hline \multicolumn{3}{|c|}{ GROUP 4: SAFEGUARDS SPECIFIC USE OF TERMS } \\
\hline Term & Definition & Ret. \\
\hline $\begin{array}{l}\text { random } \\
\text { sampling }\end{array}$ & 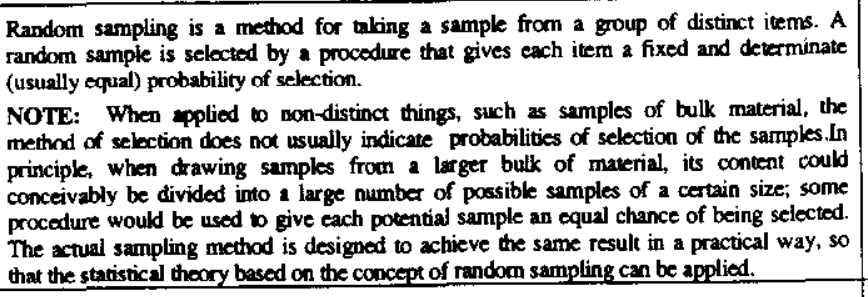 & $\begin{array}{c}{[56]} \\
2.8\end{array}$ \\
\hline $\begin{array}{l}\text { inspection by } \\
\text { attributes }\end{array}$ & $\begin{array}{l}\text { In attribtites inspection, the itern inspected is classified as being either acceptable or not } \\
\text { (i.e. a defect) on the basis of the measurement. } \\
\text { NOTE: Atributs inspection has nothing to do with the guality of measurement. }\end{array}$ & $\begin{array}{l}{[56]} \\
6.2\end{array}$ \\
\hline arm level & $\begin{array}{l}\text { A sywonym for a critical value in the terminology of testing an hypothesis. } \\
\text { NOTE: In the subjoct context, the alarm level is the value of an operator-inspector } \\
\text { difference which, if exceeded in absotute vahe, is cause for labelling the iters in question } \\
\text { a defect during inspection by attributes. }\end{array}$ & \\
\hline $\begin{array}{l}\text { significant } \\
\text { difference, } \\
\text { defect, or } \\
\text { discrepancy }\end{array}$ & $\begin{array}{l}\text { Three syounyms for an operator-inspector difference that exceeds the alarm level in } \\
\text { absolute value. }\end{array}$ & $\begin{array}{c}{[114]} \\
8.21\end{array}$ \\
\hline $\begin{array}{c}\text { decection } \\
\text { probability }\end{array}$ & $\begin{array}{l}\text { The probubility that in item with a true operator-inspector difference of a given artiount } \\
\text { will be declared to be a discrepancy. More generally, when refering to safeguards } \\
\text { index such as MUF or D, it is the probability that the index will be found to differ } \\
\text { significandy from its bypothesised value for a given true value of the index. }\end{array}$ & $\begin{array}{r}{[114]} \\
5.17\end{array}$ \\
\hline false alarm & $\begin{array}{l}\text { In attribute testing. declaring a item to be a defect when the true operator-inspector } \\
\text { difference is zero is a false alarm. A similar definition applies to tests on MUF and } \hat{D} 0\end{array}$ & $\begin{array}{c}{[114]} \\
5.18\end{array}$ \\
\hline risk & $\begin{array}{l}\text { A synonym for the probability of reaching the incorrect conclusion in bypothesis testing, } \\
\text { Two types of risks are usually considered: } \\
\text { 1. the risk of falke alarm, definod above. } \\
\text { 2. the risk of non-detection, associaned with the failure to detect a "tnue"defect. }\end{array}$ & \\
\hline
\end{tabular}




\title{
Attachment 1
}

\author{
International Target Values 2000 for Measurement Uncertainties in Safeguarding Nuclear \\ Materials \\ Page 39 of 48
}

\section{Annex 2 \\ Use of Performance Values for Inspection Purposes and Their Limitations}

The Performance Values (see chapter 3) are used in planning inspections and in drawing inferences based on the declared values of the operator and on the measured values of the inspector ${ }^{[56]}$.

From an inspection planning viewpoint, they allow calculation of sample sizes for NDA and for DA verification methods that are optimal with respect to achieving the desired level of defect detection probability with the minimum number of samples.

When evaluating the verification data, they serve first to define item-level alarms, or reject limits, such that if a given item paired difference, $d_{i j}$ exceeds the limit $L$ in absolute value, it is identified as a discrepancy, where $\mathrm{L}$ is defined by the equation:

$$
\mathrm{L}=\mathrm{z} a\left[\mathrm{u}^{2}(\mathrm{r})+\mathrm{u}^{2}(\mathrm{~s})\right]^{2}
$$

where $z_{\alpha}$ is the normal probability distribution factor associated with the probability $\alpha$ of declaring a false alarm. Current practice is to take $z_{\alpha}=3$, which results in a false alarm probability of less than $0.3 \%$.

The item paired differences are calculated on either an absolute or relative basis, as was mentioned in chapter 3. Of course, for a homogeneous stratum, it makes no difference whether absolute or relative differences are calculated.

In addition to defining attribute test reject limits as just described, performance values are also used in calculating the variances used in material balance evaluations for material unaccounted for (MUF), operator-inspector difference (D), and the inspector's estimate of MUF, (MUF-D).

In a large facility the probability of detection will be driven by the amount of marerial. Regardless of how accurately and precisely material is measured, $\sigma$ will be large because the amount of material is large. In such cases, the probability of detecting diversion by means of a material balance evaluation will be small and additional safeguards measures such as near realtime accountancy (NRTA) are called for.

The users of the Performance Values must remain aware of a number of limitations in their meaning or content.

Plant operational or economic constraints may inflate the variance components of the operator-inspector differences significantly compared to the capability of current measurement technology. The safeguards inspector must indeed verify that the uncertainties in the plant measurement system are not deliberately inflated in order to reduce the detection capability of the verification measurements. The latter concern increases with the throughput or material inventory of the plant. There will therefore always be a need for Target Values providing an accepted measure of the capability of current measurement technology under reasonably economic and operational conditions encountered in the industry.

Conversely, paired comparisons do not detect the measurement errors or uncertainties, which are common to the operator and inspector. For example, if both use the same reference material for calibration, the uncertainty of the certified value of the reference material will 


\title{
Attachment 1
}

\author{
International Target Values 2000 for Measurement Uncertainties in Safeguarding Nuclear \\ Materials \\ Page 40 of 48
}

appear as a common systematic component in both results. The common component can also be of a random nature; random sampling etrors are common, for instance, when the operator and the inspector measure the same sample or separate aliquots of the same sample.

These common components do not affect the uncertainties of the differences between operator's and inspector's measurements on a single strabum. They can, however, mask a potential bias with respect to the true amount of material. Consequently the use of Performance Values can lead to underestimation of the total uncertainties in the operator's declarations or in the material balance differences over the plant. Independent measurement evidence, free from such common mode uncertainties, is hence needed.

The user of the Performance Values must also know that the estimate of the between inspection effects, $s(\Delta)$, becomes less precise as the random uncertainty component, $s(\varepsilon)$, increases. When the inspector's uncertainties are large compared to the operator's values, it becomes difficult to obtain a precise estimate of the operator's uncertainties, and vice-versa. This is frequently the case when the operator's data come from DA measurements while the inspector measures by NDA. The paired comparisons can lead to an overestimation of the random uncertainties of the operator's DA measurements, and, at the same time, to a poor estimate of the between-inspection effects in the inspector's NDA results. As a further complication. estimates of these parameters will be affected when the operator's values are based in part on nominal or average values. A separate evaluation of the performance of individual measurement methods is necessary to guard against such potential problems. 


\section{Attachment 1}

\section{International Target Values 2000 for Measurement Uncertainties in Safeguarding Nuclear Materials}

Page 41 of 48

\section{References}

[1] INTERNATIONAL ATOMIC ENERGY AGENCY, The Structure and Content of Agreements between the Agency and States Required in Connection with the Treaty on the Non-Proliferation of Nuclear Weapons. INFCIRC/153 (corrected), para. 55 Vienna (1972).

[2] INTERNATIONAL ATOMIC ENERGY AGENCY, INFCIRC/193, Vienna (1973)

[3] INTERNATIONAL, ATOMIC ENERGY AGENCY, IAEA Safeguards Glossary, para. 120, IAEA/SG/INF/1 (Rev. 1), Vienna (1987) 27.

[4] DE BIEVRE, P., DE REGGE, P., "1979 Target Values for uncertainty components of destructive analysis methods", Minutes of the Meeting of the ESARDA/WGDA in Brussels, April 23-24, 1979, SCK, Mol, Belgium (1979).

[5] DE BIEVRE, P., et al., 1983 Target Values for uncertainty components in fissile element and isotope assay, ESARDA Bulletin 6 (1983) 1 .

[6] DE BIEVRE, P., et al., "1987 Target Values for uncertainty components in fissile isotope and element Assay", (IAEA Proc. Symp. Nucl. Safeguards Technology Vienna, 1986), IAEA, Vienna (1987) 649-662.

[7] DE BIEVRE. P.. et al.. "Random uncertainties in sampling and element assay of nuclear materials; target values 1988", ESARDA Bulletin 13 (1987) 8 .

[8] KUHN, E., et al., "1993 International Target Values for Uncertainty Components in Fissile Isotope and Element Accountancy for the Effective Safeguarding of Nuclear Materials", IAEA STR-294, LAEA. Vienna (1994).

[9] DERON, S., et.al., "1993 International Target Values for Uncertainty Components in Measurements of Nuclear Material for Safeguards Purposes", ESARDA Bulletin 23, JRC, Ispra (1994)

[10] DERON, S., et.al., , "1993 International Target Values for Uncertainty Components in Fissile Isotope and Element Accountancy for the Effective Safeguarding of Nuclear Materials", Joumal of Nuclear Materials Management, Volume XXII, Number II, January 1997.

[11] "1993 International Target Values for Uncertainty Components in Fissile Isotope and Element Accountancy for the Effective Safeguarding of Nuclear Materials", Japanese Translation, Science and Technology Agency, Japan, (1993).

[12] BIPM, IEC, ISO. IUPAC, IUPAP, OIML, "Guide to the Expression of Uncertainty in Measurement", Conrected and Reprinted First Edition 1995, ISO, Geneva, (1995).

[13] TAYLOR. B.N., KUYATT. C.E. "Guidelines for Evaluating and Expressing the Uncertainty of NIST Measurement Results", NIST Technical Note 1297, 1994 Edition, US Government Printing Office, Washington, (1994).

[14] EURACHEM/CITAC Guide, "Quantifying Uncertainty in Analytical Measurement", Second Edition, EURACHEM, (2000). 


\section{Attachment 1}

\section{International Target Values 2000 for Measurement Uncertainties in Safeguarding Nuclear Materials}

Page 42 of 48

[15] KUHN, E., et al., "The ESARDA Target Values: are they achievable in safeguards measurements", (Transactions Amer. Nucl. Soc. Winter Meeting San Francisco, 1989), ANS, La Grange, IL 60 (!989) 221-222.

[16] DE BIEVRE, P., et al., "The European Commission's safeguards analytical measurements laboratory network", (Proc. $13^{\text {th }}$ Annual ESARDA Symposium Avignon, 1991), ESARDA. Ispra (1991) 107.

[17] OTTMAR, H., EBERLE, H., The Hybrid K-edge/K-XRF Densitometer, Principles, Design, Performance, Rep. KfK 4590, KfK, Karlstuhe (1991).

[18] GUNNINK, R., MGA: A Gamma Spectrum Analysis Code for Determining Plutonium Isotopic Abundances, UCRL-LR-103220, 1, 2, LLNL, Livermore, CA (1990).

[19] KUHN, E., et al., The NBL-Potentiometric Titration of Uranium; Experience of the Safeguards Analytical Laboratory, Rep. IAEA/RL/62, IAEA, Vienna (1979).

[20] DE BIEVRE, P., Isotope Dilution Mass Spectrometry in Trace Metal Analysis in Biological Specimens, Biomedical Publication, Fostes City, CA (1985).

[21] MATUSSEK, P., et al., Routine Use and Recent Developments of the COMPUCEA Instrument, ESARDA Annual Symposium, Montpeilier, France (1997)

[22] CROMBOOM, O, et al., Qualification of the Plutonium Assay Techniques for an OnSite Laboratory, $17^{\text {th }}$ ESARDA Symposium on Safeguards and Nuclear Mat. Management, Aachen, (1995)

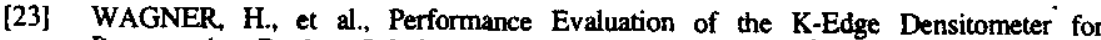
Reprocessing Ptoduct Solutions - 8 Years of Operation, 15 ${ }^{\mathrm{h}}$ ESARDA Symposium, Rome (1993)

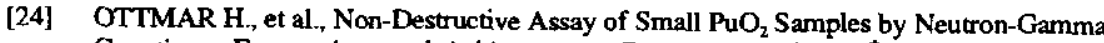
Counting - Expectations and Achievements, Proceedings of the $5^{\mathrm{k}}$ International ANS Conference, Jackson Hole, USA (1995)

[25] OTTMAR H., et al., An Empirical Measurement of the Specific ${ }^{200} \mathrm{Pu}$-Effective Mass of ${ }^{208} \mathrm{Pu}$ and ${ }^{242} \mathrm{Pu}, 21 *$ ESARDA Symposium on Safeguards and Nuclear Mat. Management, Sevilla (1999)

[26] BLOHM-HIEBER U., et al, Hybrid K-Edge Densitometer - More than 10 Years of Euratom Safeguards Experience, $39^{\text {th }}$ Annual Meeting, INMM, Naples (1998)

[27] MOREL. J., et al., Intercomparison of Plutonium Isotopic Composition Measurements by X-and Gamma-Ray Spectrometry; Results from the PIDIE Exercise, Rep. LPRI 91/278-MARS, DAMRI. CEA, Saclay (1991).

[28] HARRY, RJ.S., PDIE, Plutonium Isotopic Determination Inter-comparison Exercise, Rep. ECN-RX.-90-044, Netherlands Energy Res. Foundation, Petten, The Netherlands (1990)

[29] VERDINGH, V., LE DUIGOU, Y., BICKEL, M., "Interlaboratory comparison exercise for the determination of uranium by potentiometric titration", (Proc. 13 ${ }^{\text {th }}$ Annual ESARDA Symposium Avignon, 1991), ESARDA, Ispra (1991), 195-201. 


\section{Attachment 1}

\section{International Target Values 2000 for Measurement Uncertainties in Safeguarding Nuclear Materials}

Page 43 of 48

[30] BICKEL, M., MICHIELS, A., HENiLRICKS, F., "Interlaboratory comparison exercise for the determination of uranium by potentiometric titration (second phase), (Proc. 15 Annual ESARDA Symposium Rome, 1993), ESARDA. Ispra (1993) 643.

[31] MOREL J., et al., Results from the Uranium Enrichment Measurement Exercise, CEA Rep. L.PRL/98/23

[32] DE ALMEIDA G., et al., "ABACCs Laboratory Intercomparison Program", Proceedings of the VI Congresso Geral de Energia Nuclear, Rio de Janeiro (1996)

[33] BARAN D., et al., "Participation of ABACC Laboratories in Measurement Intercomparison Programs", Proceedings of the $40^{*}$ Meeting of the INMM, Phoenix (1999)

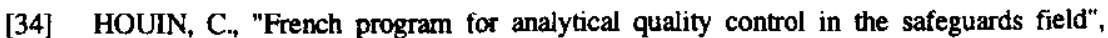
(Proc. $9^{\text {h }}$ Annual ESARDA Symposium London, 1987), ESARDA, Ispra (1987) 381.

[35] DE BIEVRE, P, WOLTERS, W. H., "The regular European interlaboratory measurement evaluation programme", (Proc. $9^{\mathrm{m}}$ Annual ESARDA Symposium London, 1987), ESARDA, Ispra (1987) 125-128.

[36] DE BIEVRE, P., MAYER, K., "How well can we measure uranium and plutonium on an interlaboratory basis". presented at the Conf. on Methods and Applications of Radioanalytical Chemistry, Kona, Hawai (1991).

[37] MAYER, K., et al., "Results of REIMEP 89 on $\mathrm{UO}_{2}$ powder; $\mathrm{UO}_{2}$ pellets; uranyle nitrate", (Proc. 13th Annual ESARDA Symposium Avignon, 1991), ESARDA, Ispra (1991) 203-213.

[38] BEYRICH, W., et al., "DoD Evaluation of REIMEP Round UF, 1987 ", presented at the ESARDA/WGDA Meeting Salamanca, Spain (1989).

[39] APARO, M., Cresti, P., REIMEP 1987, An Interlaboratory ${ }^{25}$ U Enrichment Determination by Gamma Measurement on Solid UF 6 Sample, Rep. RT/COMB/87/15, ENEA, Casaccia (1988).

[40] DE BOLLE, $W_{.,}$et al., "REIMEP 1992 - Uranium hexafluoride. Preparation and Characterisation of the Material", (Proc. 15 Annual ESARDA Symposium, Rome 1993), ESARDA, Ispra (1993) 639.

[41] MAYER, K., et al., "Performance Values of the Assay of Fissile Material as Derived from REIMEP", (PToc. 15" Annual ESARDA Symposium, Rome 1993), ESARDA, Ispra (1993) 465.

[42] CETAMA, Progranme d'Evaluation de la Qualité du Résultat d'Analyse dans l'Industrie Nucléaire (EQRAIN); Programme N 4, 1990-1991, Nitrate d'Uranyle, Rep. TEC 92-1, CEA, Fontenay-aux-Roses(1992).

[43] CETAMA, Programme d'Evaluation de la Qualité du Résultat d'Analyse dans l'Industrie Nucleaire (EQRAIN). Programme $N^{\circ} 4,1990-1991$, Nitrate de Plutonium, Rep. TEC $92-$ 2, CEA, Fontenay-aux-Roses (1992). 


\section{Attachment 1}

\section{International Target Values 2000 for Measurement Uncertainties in Safeguarding Nuclear Materials}

Page 44 of 48

[44] PEROLAT, J. P., "Progranme d'Evaluation de ii Qualité du Résultat d"Analyse dans I'Industrie Nucléaire - Bilan de Cinq Programmes", (Proc. 15 Annual ESARDA Symposium, Rome 1993), ESARDA, Ispra (1993) 453.

[45] CACIC, C. G., Safeguards Measurement Evaluation Program, Phase I, Final Report, Rep. NBL-319, USDOE, Argonne, IL (1988)

[46] MITCHELL, W. G., Measurement technology at selected DOE facilities: a status report. J. Nucl. Mat. Man., Vol. XX, 4 (1992) 32-42.

[47] EG \& G MOUND APPLIED TECHNOLOGIES, Calorimetry Exchange Programme Annual Data Report for 1988, Rep. MLM-MU-89-68-0003, EG \& G Miamisburg. O (1989).

[48] EG \& G MOUND APPLIED TECHNOLOGIES, Calorimetry Exchange Programme Annual Data Report for 1990, Rep. MLM-MU-91-63-0005, EG \& G, Miamisburg, O (1991).

[49] AMERICAN SOCIETY FOR QUALITY CONTROL, Quality Management and Quality System Elements for Laboratories, ANSWASQC Standard Q2-1991, ASQC Wisconsin (1990).

[50] ISO 9001:1994, "Quality Systems - Model for quality assurance in design, development, production, installation and servicing", ISO, Geneva (1994).

[51] AMERICAN NATIONAL STANDARDS INSTITUTE, INC., Measurement Control Program - Analytical Chemistry Laboratory, ANSI/N 15.51-90, ANSI, New York (1990).

[52] BICKEL M., et al., Workshop on Quality Requirements for Safeguards NDA, Proc. of the 21* Annual ESARDA Meeting, Sevilla (1999)

[53] ESARDA NDA Working Group. Proceedings of the International Workshop on Quality Requirements for NDA Measurements, ISSN 1018-5593, Ispra, (1998)

[54] ISO 3534-1:1993, "Statistics - Vocabulary and Symbols - Part 1: Probability and general statistical terms", ISO Standards Handbook, Statistical Methods for Quality Control, Vol. 1, Fourth Edition, ISO, Geneva, (1995).

[55] BIPM, IEC, IFCC, ISO, IUPAC, IUPAP, OIML, International Vocabulary of Basic and General Terms in Metrology, Second Edition, ISO, Geneva, (1993).

[56] IAEA, "Statistical Concepts and Techniques for IAEA Safeguards". Fifth Edition, IAEA/SG/SCT/5, IAEA, Vienna (1998)

[57] SEARLE, S.R., "Linear Models", John Wiley \& Sons, New York (1997). (Re-edition of textbook published first in 1971).

[58] JAECH, J.L., "Statistical Methods in Nuclear Material Control", TD26298, USAEC, US Govern. Printing Office, Washington (1973).

[59] JAECH, J.L., "Statistical analysis of measurement errors", Wiley, New York (1985). 


\section{Attachment 1}

\section{International Target Values 2000 for Measurement Uncertainties in Safeguarding Nuclear Materials Page 45 of 48}

[60] MARTIN, K., "Basic Document to Determine Randon and Sy stematic Error Variances from Paired Dara", Version 8, Doc 07/96, Euratom Safeguards Office, Luxentbourg. (1996).

[61] ESTEBAN A.. CRISTALLINI O.. "Comparacion de los Resultados de los Analisis Destructivos entre IAEA y ABACC", INFORME ABACC-BA-10, ABACC, Rio de Janeiro (1999).

[62] GUARDINI, S., et al. "ESARDA performance values of non destructive assay techniques applied in safeguards". (Proc. $4^{\text {th }}$ Intemational Conference on Facility Operations-Safeguards Interface Albuquerque, 1991), ANS, La Grange, IL (1991) 448.

[63] GUARDNI, S., "Performance Values of Non-Destructive Assay (NDA) Techniques Applied to Safeguards: The 1993 Evaluation by the ESARDA NDA Working Group", (Proc. 15" Annual ESARDA Symposium, Rome 1993), ESARDA, Ispra (1993) 469.

[64] JAECH, J., Russell, M, Algorithms to Calculate Sample Sizes for Inspection Sampling Plans, STR-261, Rev. 1, IAEA, Vienna (1991).

[65] SPALETTO, 1., SMITH. M.M., SORIANO, M.D., Safcguards Measurement Evaluation Programme, FY 98, Rep. NBL-352, USDOE, Argonne, IL (May 1999).

[66] CARCHON, E., de Regge, P., and Franssen, F., Reprocessing Input Tank Calitration Exercise (RITCEX), Rep. BLG 588, 1,2 (1985).

[67] BOKELUND, H., et al., An International Collahorative Exercise on the Calibration of a Model Reprocessing Plant Accountancy (CALDEX) Tank Using Lutecium Trapcer, Meeting Minutes, ESARDA/RIV Work Group, October 1993, Ispra, Italy.

[68] CAUCHETIER, P., "Calibration of an accountability tank using bubbling pressure measurements", (Proc. 15 $5^{\text {t }}$ Annual ESARDA Symposium, Rome 1993), ESARDA, Ispra (1993) 243.

[69] NEUUILLY, M., "Calibration of UP 2-800 (La Hague) accountability tank". (Proc. 15 Annual ESARDA Symposium, Rome 1993), ESARA Ispta (1993) 249.

[70] HEIN, H. J, Lausch, W., Schwertner, W., Volumetric Assay in an 800-Liter Ring Slab Using a Lithium-Magnesium-Uranium Tracer, Rep. JOPAG/10.82-PRG-56 (1982).

[71] TRINCHERINI, P. R., Volume and Mass Measurenent in the Input Accountability Tank of the Reprocessing Plant by the IDMS Tracer Technique, Rep. EUR 12623 EN, Joint Research Centre, Ispra (1990).

[72] REED, W. J, et al., Special Meeting of ESARDARIV Work Group on Tracer Calibration Exercise of CALDEX Project, March 1991, Harwell, UK. and Nov. 1991 Pierrelatte, France.

[73] CAUCHETIER, $\mathbf{P}$., "Experience with the use of a lutetium tracer at a spent fuel solution accountability tank", T AMELAB Meeting, Ispra (1992).

[74] VERDINGH. V., et al., "Repeatability and Reproducibility of Gravimetric Uranium Determinations in $\mathrm{UO}_{2}$ Pellets", CEC, Nuclear Science and Technology (1985), Com. 4182 . 


\section{Attachment 1}

\section{International Target Values 2000 for Measurement Uncertainties in Safeguarding Nuclear Materials Page 46 of 48}

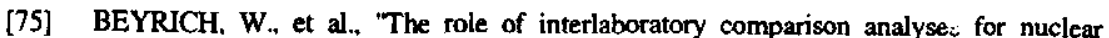
safeguards delineated by the results of the experiments JEX-70, and IDA-72" presented at the Eighteenth Conference on Anal. Chem. in Nucl. Technology, Gailinburg, TN (1974).

[76] BEYRICH, W., et al., The IDA 80 Measurement Evaluation Ptogramme on Mass Spoctrometric isotope Dilution Analysis of Uranium and Plutonium, Vol. I, XnX 3760, EUR 7990e, and Vol. II. KfK 3761, EUR 7991e, Karlsruhe (1984).

[77] GUARDINI, S., et al., Quality Control Provisions Applied in the Preparation and Characterization of Pu-bearing PERLA Standards, Rep. EUR 13038 EN, Joint Research Center, Ispra (1990).

[78] GUARDINI, S., et al., Procurement and Characterization of LEU Special Nuclear

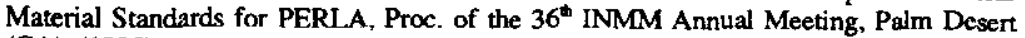
(CA), (1995)

[79] GUARDINI, S., et al., "Preparation and Characterization of NDA Reference Materials for the Russian Methodology and Training Centre", Proc. of the 41" INMM Annual Meeting, New Orleans (2000)

[80] EURACHEM Guide, "The Fitness for Purpose of Analytical Methods - A Laboratory Guide to Method Validation and Related Topics", EURACHEM, Brussel, (1998).

[81] KUVIK, $\mathrm{V}_{\text {., }}$ et al., The MacDonald and Savage titrimetric procedure scaled down to 4 mg sized plutonium samples. Part 1. Basic potentiometric procedure, Anal. Chim. Acta 256 (1992) 163-176.

[82] AGGARWAL S. K, et al., Comparative Study of ${ }^{209} \mathrm{Pu}$, ${ }^{200} \mathrm{Pu}$ and ${ }^{201} \mathrm{Pu}$ spikes for determining plutonium concentrations by isotope dilution thermal ionization mass spectrometry, Intern. J. Mass Spec. and Ion. Proc. 71 (1986) 221-231.

[83] LASZLO, G., et. al., "Optimal sample to tracer ratio for isotope dilution mass spectrometry: the poly isotope case", (Proc. 13 $3^{\text {th }}$ Annual ESARDA Symposium, Avignon, 1991), ESARDA, Ispra (1991) 219.

[84] HOLLAND, M. K., et al., The New Brunswick Laboratory Controlled Potential Coulometric Method for the Determination of Plutonium, Rep. NBL-299, USDOE, Argonne, IL (1981).

[85] WAGNER, H. G., et al., "On-Site Analytical Measurements for Inpur Accountancy Verification in a Large Reprocessing Plant by Hybrid K-Edge" Facility Operations-Safeguards Interface, ANS, Albuquerque, 1991), ANS, La Grange, IL (1991) 164.

[86] ibid., "NDA of PuO 2 Poiwder Samples", p. 449

[87] ibid., "Field Experience of EURATOM with LLNL-MGA Code for Pu Gamma Spectroscopy", p. 299.

[88] DAVIDSON, D., et al., "A new high-accuracy combined neutron/gamma counter for in glove-box measurements of $\mathrm{PuO}_{2}$ and MOX safeguards samples". (Proc. 15 $5^{\text {th }}$ ESARDA Annual Symposium, Rome, 1993), ESARDA, Ispra (1993) 585. 


\section{Attachment 1}

\section{International Target Values 2000 for Measurement Uncertainties in Safeguarding Nuclear Materials}

Page 47 of 48

[89] ENSSLIN, N., et al., "Some Target Assay Uncertainties for Passive Neutror Coincidence Counting", J. Nucl. Mat. Man., XIX (1990) 610.

[90] SAMPSON, T. E., PTecision of Gamma-Ray Measurements of the Effective Specific Power and Effective ${ }^{200} \mathrm{Pu}$ Fraction of Plutonium, Rep. LA-UR-92-883, LANL, Los Alamos Nat. Lab. (1992).

[91] AMERICAN NATIONAL STANDARDS INSTITUTE, INC., Pu-bearing Solids Calibration Techniques for Calorimetric Assay, ANSI 15.22-1987, ANSI, New York (1987).

[92] DONOHUE, $D_{\text {. }}$ et al., "Spent fuel accountability measurements by חDMS using a common large-size dried spike ((LSD)", (Proc. 15 ${ }^{\text {th }}$ Annual ESARDA Symposium, Rome 1993), ESARDA, Ispra (1993) 491.

[93] DE BIEVRE, P., et al.,"Solid spikes from CBNM for Input Analysis", (Proc. 13 $3^{\text {th }}$ Annual ESARDA Symposium, Avignon, 1991), ESARDA, Ispra (1991) 229.

[94] CALLIS, E. L., "High Precision ( $0.01 \%)$, uranium isotope ratio measurements by thermal ionization mass spectrometry utilizing a double spike technique", (Proc. Conf. on Analyt. Chem. in Nucl. Technology Gatlinburg, 1982) (W.S. Lyon, Ed,), Ann Arbor Science (1982) 115-123.

[95] CALLIS, E. L., "High precision isotopic analyses of uranium and plutonium by total sample volatilization and signal integration", Int. J. Mass Spectrometry and Ion Processes 103 (1991) 93.

[96] DE REGGE, P., FAJGEL, A., "The IAEA Guide on Quantifying Uncertainty' in Nuclear Analytical Measurements", TECDOC Series, LAEA, Vienna, [in preparation]

[97] AIGNER, $H$., et al., "Use of $Q C$ results for the assessment of analytical measurement uncertainties", submitted to Accreditation and Quality Assurance, Journal, (under review); presented at the $41^{*}$ INMM Ann. Meet., (Jul. 2000).

[98] "IAEA Safeguards Techniques and Equipment". International Nuclear Verification Series No 1, IAEA, Vienna, (1997).

[99] LAEA Safeguards Manual, Pant SMO, SMO 7.1, Annex 1, LAEA, Vienna (1992-09-30).

[100] KUHN, E., et al., "Destructive Analysis and Evaluation Services for Nuclear Material Accountability Verifications", STR-69 Rev. 3, IAEA, Vienna, (October 1996).

[101] INTERNATTONAL ATOMIC ENERGY AGENCY, Safeguards Criteria 1991-1995. Dept. of Safeguards, LAEA, Vienna (1992).

[102] DERON, S, "How to use the ESARDA Target Values for Sampling and Element Assay", ESARDA Bulletin, 13, 17, (1987).

[103] AMERICAN SOCIETY FOR TESTING AND MATERIALS, "Standard Practice for Sampling Nuclear materials in Multi Container Lots" C970-87, 12.01 Annual Book of ASTM Standards (1991).

[104] ibid., "Standard Practice for Sampling Liquid Uranium Hexafluoride", C1052-85. 


\section{Attachment 1}

\section{International Target Values 2000 for Measurement Uncertainties in Safeguarding Nuclear} Materials

\section{Page 48 of 48}

[106] NUCLEAR REGULATORY COMMISSION, Considerations for Sampling Nuclear Materials for SNM Accounting Measurements, Rep. NUREG/CR-0087, Washington, DC (1987).

[107] NUCLEAR REGULATORY COMMISSION, Methods for the Accountability of Reprocessing Plant Dissolver and Waste Solutions, Rep. NUREG/CR-0515, Washington, $\mathrm{DC}$ (1978).

[108] NUCLEAR REGULATORY COMMISSION, Methods for the Accountability of Uranium Dioxide. Rep. NUREG-75/010, Washington, DC (1975).

[109] ATOMIC ENERGY COMMISSION, Methods for the Accountability of Plutonium Dioxide, Rep. WASH 1335, Washington, DC (1974).

[110] ATOMIC ENERGY COMMISSION, Methods for the Accountability of Plutonium Nitrate Solutions, Rep. WASH 1282, Washington. DC (1974).

[111] ISO 11482:1993, "Guidelines for plutonium dioxide (PuO2) sampling in a nuclear reprocessing plant", ISO, Geneva (1993).

[112] ISO \$2803:1997, "Representative sampling of plutonium nitrate solutions for determination of plutonitum concentration", ISÖ, Geneva (1997).

[113] ISO 11598:1995, "Requirements for representative sampling of uranyl nitrate solutions for the determination of uranium concentration", ISO, Geneva (1995).

[114] IAEA Safeguards Glossary, 2000 Edition, IAEA, Vienna, (2000). 
Attachment 2

Destructive Analysis Method Compendium

Page 1 of 40

"Johnson-Miller, Kimberly"

<Kimberly.Johnson-

Millerech.doe.govs

05/07/02 02:20 PM

\begin{abstract}
"Michael Holland (E-mail 2)" <Michael.holland@srs.gov>, "Robert Marshall (E-mail 2)" <rmarshall lanl.gov>
\end{abstract}

ct: FW: Special Note (Red) on DA Compendium Document

Attached is a draft copy of the " Destructive Assay Method Compendium". New Brunswick Laboratory has updated this document with the latest International Target values. As you may know, so-11 is interested in publishing this as a Technical Standard. I have been tasked to coordinate the final document (along with Kelly Coady) through the DOE Technical standard process.

Please review the "DA Compendium" in its entirety (however, most of the changes were made to pages 21-29) and provide comments /suggestions back to me. I am requesting that all comments/suggestions to be sent to me at mailto: Kimberly.Johnson-Millerech.doe.gov no later than June 3, 2002 .

If you have any questions, please feel free to contact me at (630)252-4334. I thank you in advance for your cooperation.

Kimberly Johnson-Miller

Manager, Nuclear Safeguards and Nonproliferation Support Program

$\ll$ DA Methods Compendium.doco.zip $>$ 


\section{Attachment 2 \\ Destructive Analysis Method Compendium \\ Page 2 of 40}

\section{Destructive Assay Methods Compendium ${ }^{1}$}

\section{Introduction.}

Analytical chemistry plays a key role in nuclear material control and accounting (MC\&A). A large part of Special Nuclear Material (SNM) inventories and virtually all of the highly attractive SNM inventories are based on sampling bulk materials followed by destructive assay (DA) of these materials. These measurements support MC\&A in process control, physical inventory verification, evaluation of the effects of process changes, detecting and resolving shipper-receiver differences, and the resolution of IAEA inspector-facility differences. The evaluation and the specification of DA, MC\&A techniques have proven difficult, in part, because of the highly specialized and technical nature of DA and because of the wide variety of methods and applications.

II. Purpose.

\section{The purpose of this guidance document is to:}

- Recommend criteria to use in evaluation of DA MC\&A capabilities.

- Provide a basis for selection of appropriate upgrades where capabilities are inadequate to support MC\&A goals.

- Provide a list of DA methods suitable for MC\&A with the following information:

$>$ performance and applications information,

$>$ strengths and limitations,

\section{$>$ references and information on cost.}

\section{Scope.}

DA involves measurements on samples taken from a larger quantity or batch; typically samples are altered by their preparation such that the sample is not returned to the batch. This document is limited to analytical methods used to quantify and characterize plutonium (Pu) and enriched uranium (EU). The US DOE and NRC identify these materials as Special Nuclear Materials (SNM).

- Limited guidance is provided on bulk measurements and sampling of bulk materials.

- $\quad$ All the included methods, alone or in conjunction with other methods, provide analysis of SNM element or isotope quantities and are appropriate for use in support of MC\&A. Most of these methods may also provide information useful for process control.

- Some methods listed herein address the determination of impurities present in SNM. These methods are limited to those typically used to measure impurities to provide interference corrections for certain DA methods.

- Appendix A provides summary information on DA methods. General references are listed which provide in-depth information on each method. For reviews of SNM assay (elemental concentration) methods References 1-4 are recommended.

\section{DA Method Evaluation and Selection Criteria.}

The primary criterion for evaluating a DA method used in support of MC\&A is determining whether or not the method provides the accuracy required to support statements on inventory assurance. Material Control and Accounting goal quantities are defined to determine the appropriate combination of MC\&A elements, including DA and non-destructive assay (NDA) measurements, which support statements of allowable inventory difference. The US approach to inventory assurance encourages and supports using highly precise and accurate analytical measurement values in inventory difference calculations. As processing of SNM has been shut down, more limited US funds have been made available for DA MC\&A measurements and a more practical approach may be needed to determine the best use of the available resources. Within established Material Balance Areas (MBAs), MC\&A goal-quantities for those MBA's

\footnotetext{
${ }^{1}$ Price Russ, LLNL; Robert Marshall, LANL; Doyle Hembree, Y-12; Michael Holland, SRS; Wanda Mitchell, NBL.
} 


\begin{tabular}{lll} 
Applicability of International and DOE Target Values & Technical Report:N-TRT-F-00001 \\
to ALD Destructive Measurement Applications (U) & Page 66 of 117 r & Rev.0 \\
\hline
\end{tabular}

\section{Attachment 2 \\ Destructive Analysis Method Compendium \\ Page 3 of 40}

can then be used to evaluate existing analytical capabilities and to determine the upgrades required. Nuclear Regulatory Commission (NRC) and International Atomic Energy Agency (IAEA) target values and goal quantities are provided for guidance in Appendix B.

With goal quantities defined, the SNM flow in a specified time period can be estimated, the fraction of that flow which would be determined by analytical chemistry can be estimated, and the acceptable percent uncertainty on the flow for the analytical measurements can be estimated. These estimates allow the precision and accuracy of the analytical measurements required to attain the declared level of assurance to be determined. Note that the performance requirements for DA depend upon the attractiveness of the material. It is absolutely essential that the overall error, which includes the combined errors from every stage of the measurement process, be considered in determining the required precision and accuracy of the analytical method. In general, the precision of the DA method must be higher than that required to simply meet a given level of assurance because errors from other sources, particularly sampling, must be taken into account. A good rule of thumb is that the DA method should contribute no more than $20 \%$ to the overall allowable error. Appendix $C$ presents an example of the type of calculation needed to evaluate the limits on DA errors consistent with detecting a goal-quantity loss of SNM from a hypothetical MBA.

A second criterion is technological suitability. All DA methods require some level of technological support, but the requirements vary widely. Readily available electronic and computer support may be needed for some methods together with high purity chemicals and certified reference materials (CRMs). Without these support resources, certain DA methods may be unusable. Each site must include an estimate of the availability of these resources to evaluate the feasibility of sustaining selected methods at a particular facility.

A third criterion is cost effectiveness. DA methods vary widely in their costs to set up and operate. Sustainability bears consideration as additional US facilities are removed from operation.

A fourth criterion is the capacity or throughput of each method. Some methods are relatively labor intensive and can only provide a few analyses per day; others are highly automated and can provide many analyses per day. Automation may be desirable not only to increase the sample throughput, but also to reduce variability in the data.

A fifth criterion is training. In general where chemists are employed, they are knowledgeable and skilled in the methods they employ. However, implementing new or enhanced DA methods at facilities may require training of chemists, technicians and support personnel which adds to the cost of implementing the methods.

\section{Sampling and bulk measurements.}

The DA of samples alone does not provide a statement of the uncertainty on the SNM inventory for MC\&A. The DA of a sample provides the elemental or isotopic information which is multiplied by the mass or volume of the bulk material from which the sample is taken. The calculated SNM mass in the bulk material has an uncertainty which includes uncertainties in the bulk material measurement (mass or volume), the degree to which the sample represents the bulk material, and the quality of the DA measurement.

The capability of the facility to take samples representative of the bulk material must be understood by the DOE oversight and the facility so that sampling error can be included in the calculation of the overall SNM inventory uncertainty. Failure to collect representative samples from bulk SNM can mask theft or cause false alarms, which undermines the credibility of MC\&A systems. Therefore, tasking the facility to evaluate its sampling error contribution to inventory difference is advised to identify inadequacies in sampling practices and to establish the accuracy and precision associated with sampling. 
Attachment 2

Destructive Analysis Method Compendium Page 4 of 40

Overall analytical uncertainty depends on both sampling and DA errors. When assessing DA measurement requirements versus assurance goals, the chemist must have a reasonable knowledge of the type and magnitude of the errors from the sample collection process. Since the error from sampling and the DA result on the sample are multiplied by the bulk mass or volume, which is typically a large number, to yield the bulk SNM quantity, the accuracy and precision needed in the measurement of the bulk mass or volume must be carefully considered. The chemist must also know the ability of the laboratory to detect larger than expected sampling errors (by other than the replicate DA measurements). If the laboratory can readily validate a set of replicate samples by a bulk measurement such as sample density measurements (and process tank density measurements, if available), then sample error can be controlled and DA method selection can be based more strictly on measurement uncertainty requirements. To save time and resources, this validation should take place before the DA measurements. If sample validation methodology is not implemented, the reliability requirements for DA measurements must be increased to ensure detection of sample errors from limited data sets on replicate DA measurements. Enhancement of a facility's capabilities for sampling bulk SNM, understanding sampling errors, and measuring bulk volumes or masses to the sufficient level of precision and accuracy may need to be made in parallel with enhancement of DA methods.

\section{REFERENCES}

1. Handbook of Nuclear Safeguards Measurement Methods, U.S. DOE Nuclear Regulatory Commission (NRC) Report, NUREG/CR-2078 (MLM-2855), D. R. Rogers, ed., Mound Laboratory, September 1983.

2. Annual Book of ASTM Standards, Volume 12.01 Nuclear Energy.

3. International Organization for Standardization, ISO Volume 27.120.30 Fissile Materials. 
\begin{tabular}{llr} 
Applicability of International and DOE Target Values & Technical Report:N-TRT-F-00001 \\
to ALD Destructive Measurement Applications (U) & Page 68 of 117 & Rev.0 \\
\hline
\end{tabular}

Attachment 2

Destructive Analysis Method Compendium

Page 5 of 40

Appendix A. Destructive Assay Methods

In this appendix, a list of the more common SNM assay and isotopic ratio methods and some supporting impurity measurement methods are provided. For each method a very concise description of the method, sample size and preparation, support equipment and supplies, calibration and standards, performance, and advantages and disadvantages are given. References are given for comprehensive information on the more complicated methods. Where references are not given use References 3 and 4 on the preceding page..

Cost estimates are based upon implementation of a capability, and include the costs for equipment, instrumentation, training and supplies. Exact costs will be facility specific. To provide rough guidance, the Team has broken the cost into the following categories: LOW $=<100 \mathrm{~K}$ dollars; MEDIUM $=100$ to $500 \mathrm{~K} ; \mathrm{HIGH}=>500 \mathrm{~K}$ 
Attachment 2

Destructive Analysis Method Compendium

Page 6 of 40

Appendix A Contents:

Appendix A.1: Plutonium Analysis

A.1.1 Ignition/Gravimetry

A.1.2 Controlled-Potential Coulometry

A.1.3 Plutonium Alpha Spectrometry

A.1.4 Alpha Counting

A.1.5 Ceric Titration of Pu with Potentiometric or Spectrophotometric Endpoint

A.1.6 Amperometric Titration of $\mathrm{Pu}$

A.1.7 Spectrophotometry of Pu (and U)

Appendix A.2: Uranium Analysis

A.2.1 Ignition/Gravimetry

A.2.2 Davies and Gray, Reduction-Oxidation Titrimetry

A.2.3 Laser-Induced Kinetic Phosphorescence

A.2.4 Spectrophotometry of U (See A.1.7 Spectrophotometry of Pu)

A.2.5 Densitometry

Appendix A3: Mass Spectrometry

A.3.1 Mass Spectrometry: Isotopic Abundance of $\mathrm{U}$ and $\mathrm{Pu}$

A.3.2 Isotope Dilution Mass Spectrometry (IDMS)

Appendix A4: Impurity Analysis

A.4.1 Spectrophotometry for iron

A.4.2 DC Arc Emission Spectroscopy for metallic impurities

A.4.3 Atomic absorption, inductively coupled plasma emission spectroscopy and mass spectrometry 
Attachment 2

\section{Destructive Analysis Method Compendium}

Page 7 of 40

\begin{tabular}{|c|c|}
\hline \multicolumn{2}{|c|}{ METHOD A.1.1: Ignition/Gravimetry of Pu } \\
\hline ELEMENT DETERMINED & $\mathrm{Pu}$ \\
\hline BASIC PRINCIPLE & $\begin{array}{l}\text { Convert a weighed portion of plutonium sample to } \mathrm{PuO}_{2} \text {, a compound of } \\
\text { known, specific composition, by heating (ignition) in a furnace to } 1200^{\circ} \mathrm{C} \\
\text { or higher, and calculate the quantity of plutonium from the known } \\
\text { composition and the total final mass of the } \mathrm{PuO}_{2} \text { formed. Correct the final } \\
\text { weight of } \mathrm{PuO}_{2} \text { for any nonvolatile impurities as determined by separate } \\
\text { analysis }\end{array}$ \\
\hline TYPICAL RESULTS & Random and Systematic errors of $0.05 \%$ to $0.2 \%$. \\
\hline SAMPLE SIZE & 5 - 10 grams \\
\hline SAMPLE TYPES & High purity plutonium materials \\
\hline ADVANTAGES & $\begin{array}{l}\text { Laboratory equipment required is simple. } \\
\text { High precision for high purity materials is readily attained. } \\
\text { Operator time per determination is small. } \\
\text { Solid samples require minimal handling. }\end{array}$ \\
\hline LIMITATIONS & $\begin{array}{l}\text { Requires known, reproducible composition of the final weighing form, } \\
\mathrm{PuO}_{2} \text {. } \\
\text { Application is limited to high purity materials such as plutonium oxalate, } \\
\text { plutonium oxide, plutonium metal, and plutonium nitrate solutions. } \\
\text { Nonvolatile impurities must be separately determined and a correction } \\
\text { applied. } \\
\text { Weighing errors. }\end{array}$ \\
\hline REFERENCES & $\begin{array}{l}\text { K. A. Swinburn and I. R. McGowan, "An Approach to the Use of } \\
\text { Plutonium Dioxide as a Chemical Reference Standard for Plutonium," } \\
\text { BNFL-205(W), British Nuclear Fuels Limited, } 1975 . \\
\text { G. R. Waterbury, R. M. Douglas, and C. F. Metz, "Thermogravimetric } \\
\text { Behavior of Plutonium Metal, Nitrate, Sulfate and Oxalate," Anal. Chem., } \\
\text { 33,1018-1023 (1961). }\end{array}$ \\
\hline COST ESTIMATE & LOW \\
\hline
\end{tabular}


Attachment 2

\section{Destructive Analysis Method Compendium}

Page 8 of 40

\begin{tabular}{|c|c|}
\hline \multicolumn{2}{|c|}{ METHOD A.1.2: Controlled Potential Coulometry of Pu } \\
\hline ELEMENT DETERMINED & $\mathrm{Pu}$ \\
\hline BASIC PRINCIPLE & $\begin{array}{l}\text { Quantitative electrolytic oxidation of } \mathrm{Pu}(\mathrm{III}) \text { to } \mathrm{Pu}(\mathrm{IV}) \text { at an electrode } \\
\text { maintained at a controlled potential with determination of the quantity of } \\
\text { Pu from the quantity of electricity required for the complete oxidation. } \\
\text { (Special case of redox titrimetry in which electrons are used as the } \\
\text { titrant.) }\end{array}$ \\
\hline TYPICAL RESULTS & $\begin{array}{l}\text { Random and systematic errors of } 0.1 \% \text { readily attained. } \\
\text { For better sample types errors of } 0.05 \% \text { are attained. }\end{array}$ \\
\hline SAMPLE SIZE & $1-10 \mathrm{mg} \mathrm{Pu}$ \\
\hline SAMPLE TYPES & $\begin{array}{l}\text { Pu metal, oxides } \\
\text { Mixed U, Pu oxides } \\
\text { Pu nitrate solutions } \\
\text { Dissolver solutions } \\
\text { Applicable to most Pu materials when ion-exchange separation is used. }\end{array}$ \\
\hline ADVANTAGES & $\begin{array}{l}\text { High precision and accuracy on relatively small quantities of Pu. } \\
\text { Relatively free of interferences. } \\
\text { Readily automated. } \\
\text { Adaptable to remote operations and analysis of irradiated materials. }\end{array}$ \\
\hline LIMITATIONS & $\begin{array}{l}\text { Moderately complex/moderately expensive instrumentation. } \\
\text { Electrolysis cell and electrode malfunctions. } \\
\text { Several interferences cause problems. } \\
\text { Weighing errors. } \\
\text { Operator errors. }\end{array}$ \\
\hline REFERENCES & $\begin{array}{l}\text { W. D. Shults, "Applications of Controlled-Potential Coulometry to the } \\
\text { Determination of Plutonium-A Review," Talanta, Vol. 10, 1963, p. 833- } \\
849 . \\
\text { T. L. Frazzini, M. K. Holland, J. R. Weiss, and C. E. Pietri, "A Digital } \\
\text { Integrator for Controlled-Potential Coulometry," Analytica Chimica Acta, } \\
\text { Vol. 129, 1981, p. } 125 . \\
\text { ASTM Standard Test Methods for Controlled-Potential Coulometric } \\
\text { Measurement of Pu, C } 1108 \text { and C 1165, both in Volume } 12.01 \\
\text { International Standard, "Controlled-Potential Coulometric Assay of } \\
\text { Plutonium," ISO } 12183 \text {. }\end{array}$ \\
\hline COST ESTIMATE & MEDIUM \\
\hline
\end{tabular}


Attachment 2

\section{Destructive Analysis Method Compendium}

Page 9 of 40

\begin{tabular}{|c|c|}
\hline \multicolumn{2}{|c|}{ METHOD A.1.3: Alpha Spectrometry of Pu } \\
\hline ELEMENT DETERMINED & $\mathrm{Pu}\left({ }^{238} \mathrm{Pu}\right.$ in support of mass spectrometry) \\
\hline TYPICAL RESULTS & Random error of $2 \%$ for $0.01 \%{ }^{238} \mathrm{Pu}$. \\
\hline BASIC PRINCIPLE & $\begin{array}{l}\text { From an alpha spectrum of a dissolved and separated Pu sample, } \\
\text { determine a ratio from measurements of the total counts from the }{ }^{238} \mathrm{Pu} \\
\text { peak regions and }{ }^{239} \mathrm{Pu}+{ }^{240} \mathrm{Pu} \text { peak regions. Calculate the }{ }^{238} \mathrm{Pu} \\
\text { abundance from the ratio obtained and abundance measurements of } \\
{ }^{239} \mathrm{Pu} \text { and }{ }^{240} \mathrm{Pu} \text { obtained from mass spectrometry of a separate portion of } \\
\text { the sample. }\end{array}$ \\
\hline SAMPLE SIZE & Samples containing $0.01-0.7$ weight percent ${ }^{238} \mathrm{Pu}$ \\
\hline SAMPLE TYPES & $\begin{array}{l}\text { Used where the }{ }^{238} \mathrm{Pu} \text { abundance is too low for mass spectrometric } \\
\text { measurement or there is interference from }{ }^{238} \mathrm{U} \text {. Pu must be dissolved } \\
\text { and separated. }\end{array}$ \\
\hline ADVANTAGES & $\begin{array}{l}\text { Allows determination of }{ }^{238} \mathrm{Pu} \text { where problems occur with mass } \\
\text { spectrometry. } \\
\text { Method is relatively simple and fast. }\end{array}$ \\
\hline LIMITATIONS & $\begin{array}{l}\text { Separation from }{ }^{241} \mathrm{Am} \text { is required. } \\
\text { Mass spectrometric determination of }{ }^{239} \mathrm{Pu} \text { and }{ }^{240} \mathrm{Pu} \text { is required. } \\
\text { Preparation of counting disk to obtain uniform sample distribution requires } \\
\text { care. } \\
\text { Uncertainties in } \mathrm{Pu} \text { isotope half-lives. }\end{array}$ \\
\hline \multicolumn{2}{|l|}{ REFERENCES } \\
\hline COST ESTIMATE & LOW \\
\hline
\end{tabular}


Attachment 2

Destructive Analysis Method Compendium

Page 10 of 40

\begin{tabular}{|c|c|}
\hline \multicolumn{2}{|c|}{ METHOD A.1.4: Alpha Counting of Pu } \\
\hline ELEMENT DETERMINED & $\mathrm{Pu}$ \\
\hline TYPICAL RESULTS & Random and systematic errors of $2-5 \%$ \\
\hline BASIC PRINCIPLE & $\begin{array}{l}\text { A sample or a separated Pu fraction is mounted on a counting disk and } \\
\text { the gross alpha activity is determined. }\end{array}$ \\
\hline SAMPLE SIZE & Adequate to give $1-5 \times 10^{5}$ counts in $5-10$ minutes \\
\hline SAMPLE TYPES & Dissolver solutions, irradiated process solutions and waste solutions. \\
\hline ADVANTAGES & $\begin{array}{l}\text { Method is relatively simple and fast. } \\
\text { Applicable to radioactive solutions requiring remote handling. }\end{array}$ \\
\hline LIMITATIONS & $\begin{array}{l}\text { Specific activity of the Pu in the sample must be known. } \\
\text { Generally requires a separation. } \\
\text { Thick or nonuniform deposits on counting disks cause errors. } \\
\text { None quantitative Pu recovery from separations cause errors. }\end{array}$ \\
\hline \multicolumn{2}{|l|}{ REFERENCES } \\
\hline COST ESTIMATE & LOW \\
\hline
\end{tabular}


Attachment 2

Destructive Analysis Method Compendium

Page 11 of 40

\begin{tabular}{|c|c|}
\hline \multicolumn{2}{|c|}{ METHOD A.1.5: Ceric Titration of Pu } \\
\hline ELEMENT DETERMINED & $\mathrm{Pu}$ \\
\hline TYPICAL RESULTS & Random and Systematic errors are $0.05 \%$ on good materials. \\
\hline BASIC PRINCIPLE & $\begin{array}{l}\text { Oxidimetric titration of } \mathrm{Pu}(\mathrm{III}) \text { to } \mathrm{Pu}(\mathrm{IV}) \text { using the oxidant } \mathrm{Ce}(\mathrm{IV}) \text { as titrant } \\
\text { with spectrophotometric detection of the end point which is observed as a } \\
\text { color change of the added ferroin indicator or potentiometric endpoint; the } \\
\mathrm{Pu} \text { in the initial sample is reduced prior to the titration using a lead } \\
\text { reductor column. }\end{array}$ \\
\hline SAMPLE SIZE & 200 to $250 \mathrm{mg} \mathrm{Pu}$ \\
\hline SAMPLE TYPES & $\begin{array}{l}\text { Pu metal, Pu oxides, Pu nitrides } \\
\text { Used primarily for relatively pure metal due to interferences. } \\
\text { (Use anion exchange separation when several interferences are present) }\end{array}$ \\
\hline ADVANTAGES & $\begin{array}{l}\text { Simple laboratory equipment. } \\
\text { High precision and accuracy on applicable samples. }\end{array}$ \\
\hline LIMITATIONS & $\begin{array}{l}\text { Subject to numerous common interferences - Fe, Cr, Ti, Mo, W, U, V } \\
\text { Relatively large sample size required. } \\
\text { Titrant - tedious and lengthy preparation; requires standardization and } \\
\text { careful storage; uncertainty of standards used yield errors. } \\
\text { Operator errors - weighing errors, titration errors. }\end{array}$ \\
\hline REFERENCES & $\begin{array}{l}\text { J. Corpel and F. Regnaud, Analytica Chimica Acta., Vol. 27, pp. 36-39, } \\
1962 .\end{array}$ \\
\hline COST ESTIMATE & LOW \\
\hline
\end{tabular}


Attachment 2

\section{Destructive Analysis Method Compendium}

Page 12 of 40

\begin{tabular}{|c|c|}
\hline \multicolumn{2}{|c|}{ METHOD A.1.6: Amperometric Titration of Pu } \\
\hline ELEMENT DETERMINED & $\mathrm{Pu}$ \\
\hline TYPICAL RESULTS & $\begin{array}{l}\text { Random errors of } 0.1-0.2 \% \text { are generally attained. Systematic errors are } \\
\text { usually better than } 0.1 \% \text {. } \\
\text { Random errors under the best conditions are better than } 0.05 \% \text {. }\end{array}$ \\
\hline BASIC PRINCIPLE & $\begin{array}{l}\text { Reductimetric titration of } \mathrm{Pu}(\mathrm{VI}) \text { to } \mathrm{Pu}(\mathrm{IV}) \text { using the reductant } \mathrm{Fe}(\mathrm{II}) \text { as } \\
\text { titrant with amperometric detection of the end point after preliminary } \\
\text { oxidation of the } \mathrm{Pu} \text { to } \mathrm{Pu}(\mathrm{VI}) \text { using excess } \mathrm{Ag}(\mathrm{II}) \text { oxide as an oxidant. } \\
\text { Amperometric titration is based on observation of the change in current at } \\
\text { a working electrode as titrant is added. In this titration the electrode } \\
\text { responds to the } \mathrm{Fe}(\mathrm{II}) \text { titrant; when the end point is exceeded a current } \\
\text { flow proportional to the excess } \mathrm{Fe}(\mathrm{II}) \text { is observed allowing detection and } \\
\text { determination of the end point. }\end{array}$ \\
\hline SAMPLE SIZE & $10-60 \mathrm{mg} \mathrm{Pu}$ \\
\hline SAMPLE TYPES & $\begin{array}{l}\text { Pu as metal, oxide, fluoride, chloride, nitrate, sulfate. } \\
\text { Pu in alloys containing uranium, iron, cobalt and aluminum. }\end{array}$ \\
\hline ADVANTAGES & $\begin{array}{l}\text { Simple laboratory equipment. } \\
\text { High precision and accuracy on relatively small samples. } \\
\text { Clear, simple end point detection. } \\
\text { Initial oxidation state of } \mathrm{Pu} \text { does not matter; all } \mathrm{Pu} \text { is oxidized to } \mathrm{Pu}(\mathrm{VI}) \text {. }\end{array}$ \\
\hline LIMITATIONS & $\begin{array}{l}\text { Subject to several interferences - cerium, chromium, vanadium and } \\
\text { manganese. } \\
\text { Titrant - requires daily standardization; subject to change. } \\
\text { Initial titration reaction is slow and difficult to follow. } \\
\text { Indicator and reference electrodes subject to problems. }\end{array}$ \\
\hline REFERENCES & $\begin{array}{l}\text { C. A. Seils, Jr., R. J. Meyer, and R. P. Larsen, "Amperometric Titration of } \\
\text { Plutonium (VI) with Iron (II)," Anal. Chem. 35, pp. 1673-1675, } 1963 .\end{array}$ \\
\hline COST ESTIMATE & LOW \\
\hline
\end{tabular}


Attachment 2

\section{Destructive Analysis Method Compendium}

Page 13 of 40

\begin{tabular}{|c|c|}
\hline \multicolumn{2}{|c|}{ METHOD A.1.7: Spectrophotometry of Pu (and U) } \\
\hline ELEMENT DETERMINED & $\mathrm{Pu}($ and $\mathrm{U})$ \\
\hline TYPICAL RESULTS & $\begin{array}{l}\text { Routine samples, Random errors of } 1 \text { - } 3 \% \text {; systematic errors of } 0.5 \% \\
\text { High purity plutonium materials, Random error of } 0.3 \% \text {; systematic error } \\
\text { of } 0.2 \%\end{array}$ \\
\hline BASIC PRINCIPLE & $\begin{array}{l}\text { Rapid determination of the concentration of specific oxidation states of } U \\
\text { and Pu by simultaneous measurement of the absorption of light by those } \\
\text { oxidation states over a range of wavelengths and fast computer } \\
\text { processing of the data based on calibration models. }\end{array}$ \\
\hline SAMPLE SIZE & $0.2-200 \mathrm{~g} / \mathrm{L} \mathrm{U}$ or $\mathrm{Pu}$ \\
\hline SAMPLE TYPES & $\mathrm{U}$ and $\mathrm{Pu}$ solutions with $\mathrm{U}(\mathrm{VI})$ and $\mathrm{Pu}(\mathrm{III})$ or $\mathrm{Pu}(\mathrm{VI})$ \\
\hline ADVANTAGES & $\begin{array}{l}\text { Rapid measurements. } \\
\text { Reasonable precision. } \\
\text { Easily interfaced to processes; reliable online measurements. } \\
\text { Rugged instrument - no moving parts. }\end{array}$ \\
\hline LIMITATIONS & $\begin{array}{l}\text { Spectral and chemical interferences. } \\
\text { Absorption is temperature and matrix dependent. } \\
\text { Calibration model errors (weighing and absorption measurement errors). } \\
\text { Operator errors - sample preparation. }\end{array}$ \\
\hline REFERENCES & $\begin{array}{l}\text { D. R. Van Hare, "Analysis of Special Recovery Samples by Pu (III) } \\
\text { Spectrophotometry," Savannah River Plant Report DP-1713, } 1985 . \\
\text { "Interference Study of the Pu(III) Spectrophotometric Assay," Journal of } \\
\text { Radioanalytical and Nuclear Chemistry, Vol 152, No. 1, 1991, pp. 207- } \\
218 .\end{array}$ \\
\hline COST ESTIMATE & LOW \\
\hline
\end{tabular}


Attachment 2

Destructive Analysis Method Compendium

Page 14 of 40

\begin{tabular}{|c|c|}
\hline \multicolumn{2}{|c|}{ METHOD A.2.1: Ignition/Gravimetry of $U$} \\
\hline ELEMENT DETERMINED & $U$ \\
\hline BASIC PRINCIPLE & $\begin{array}{l}\text { Convert a weighed portion of uranium sample to } \mathrm{U}_{3} \mathrm{O}_{8} \text {, a compound of } \\
\text { known, specific composition, by heating (ignition) in a furnace open to the } \\
\text { air and calculate the quantity of uranium from the known composition and } \\
\text { the total final mass of the } \mathrm{U}_{3} \mathrm{O}_{8} \text { formed. Nonvolatile impurities must be } \\
\text { determined by a separate determination. }\end{array}$ \\
\hline TYPICAL RESULTS & Random errors of 0.01 to $0.08 \%$ and Systematic errors of 0.01 to $0.02 \%$. \\
\hline SAMPLE SIZE & 5 - 10 grams \\
\hline SAMPLE TYPES & $\begin{array}{l}\text { High purity uranium materials - metal, } \mathrm{UO}_{2}, \mathrm{UO}_{3}, \mathrm{U}_{3} \mathrm{O}_{8}, \mathrm{UF}_{4}, \mathrm{UF}_{6} \text {, Uranyl } \\
\text { nitrate solution }\end{array}$ \\
\hline ADVANTAGES & $\begin{array}{l}\text { Laboratory equipment required is simple. } \\
\text { High precision is readily attained. } \\
\text { Operator time per determination is small. } \\
\text { Solid samples require minimal handling. }\end{array}$ \\
\hline LIMITATIONS & $\begin{array}{l}\text { Requires known, reproducible composition of the final weighing form, } \\
\mathrm{U}_{3} \mathrm{O}_{8} \text {. } \\
\text { Application is limited to high purity materials; impurity content and } \\
\text { corrections can be problems. } \\
\text { Weighing errors. }\end{array}$ \\
\hline REFERENCES & $\begin{array}{l}\text { O. A. Vita, C. R. Walker, and E. Litteral, "The gravimetric Determination of } \\
\text { Uranium in Uranyl Nitrate," Anal. Chimica Acta., Vol 64, pp. } 249-257 \text {, } \\
1973 . \\
\text { F. B. Stephens, R. G. Gutmacher, K. Ernst, J. E. Harrar, and S. P. Turel, } \\
\text { "Methods for the Accountability of Uranium Dioxide," NUREG-75/010, pp. } \\
\text { 4-44 to 4051, U.S. Regulatory Commission, June } 1975 .\end{array}$ \\
\hline COST ESTIMATE & LOW \\
\hline
\end{tabular}


Attachment 2

\section{Destructive Analysis Method Compendium}

Page 15 of 40

\begin{tabular}{|c|c|}
\hline ELEMENT DETERMINED & $U$ \\
\hline BASIC PRINCIPLE & $\begin{array}{l}\text { Redox titration of } \mathrm{U}(\mathrm{IV}) \text { to } \mathrm{U}(\mathrm{VI}) \text { with potentiometric end point detection } \\
\text { after chemical pretreatment of the sample solution to adjust the oxidation } \\
\text { states of species present so that uranium is essentially the only } \\
\text { substance titratable by the oxidant. }\end{array}$ \\
\hline TYPICAL RESULTS & $\begin{array}{l}\text { Random and systematic errors of } 0.1 \% \text { readily attained. } \\
\text { For better sample types errors of } 0.05 \% \text { are attained. }\end{array}$ \\
\hline SAMPLE SIZE & $10-50 \mathrm{mg} \mathrm{U}$ \\
\hline SAMPLE TYPES & $\begin{array}{l}\text { Applicable to uranium materials from essentially all stages of the nuclear } \\
\text { fuel cycle - uranium ores, metal, oxides, salts and alloys. }\end{array}$ \\
\hline ADVANTAGES & $\begin{array}{l}\text { Good precision and accuracy are readily attained. } \\
\text { Laboratory equipment is relatively simple. } \\
\text { Few interferences; most can be removed or controlled. } \\
\text { Groups of } 12-15 \text { samples handled together. } \\
\text { Relatively easily automated. }\end{array}$ \\
\hline LIMITATIONS & $\begin{array}{l}\text { Operator errors; requires strict adherence to details. } \\
\text { Requires full time and attention of analyst. } \\
\text { Requires care in selection and testing reagents. } \\
\text { Indicator and reference electrode problems occur. } \\
\text { Errors/changes in titrant value. } \\
\text { Weighing errors. }\end{array}$ \\
\hline REFERENCES & $\begin{array}{l}\text { W. Davis and W. Gray, "Rapid and Specific Volumetric Method for the } \\
\text { Precise Determination of Uranium Using Ferrous Sulfate as Reductant," } \\
\text { Talanta, 1964, p. } 1203 . \\
\text { A.W. Eberle and M. W. Lerner, "Effect of Added Vanadyl lon on the } \\
\text { Accuracy of the New Brunswick Laboratory Method (Ferrous lon } \\
\text { Reduction ) of Determining Uranium," NBL-258, 1971, p. } 22 \text {. }\end{array}$ \\
\hline COST ESTIMATES & $\begin{array}{l}\text { LOW for Manual } \\
\text { MEDIUM if Automated }\end{array}$ \\
\hline
\end{tabular}


Attachment 2

\section{Destructive Analysis Method Compendium}

Page 16 of 40

\begin{tabular}{|c|c|}
\hline ELEMENT DETERMINED & U \\
\hline BASIC PRINCIPLE & $\begin{array}{l}\text { The method utilizes the measurement of the intensity of the green } \\
\text { phosphorescence of } U \text { which results from excitation with ultraviolet light } \\
\text { from a pulsed nitrogen/dye laser. The phosphorescence of the } \mathrm{UO}_{2}^{+2} \text { is } \\
\text { filtered, amplified, and measured by a computer which also calculates the } \\
\text { result. To prevent quenching of the phosphorescence, a phosphate- } \\
\text { based complexing reagent is added. The kinetic analysis of the uranyl } \\
\text { phosphorescence provides a highly precise and accurate measurement, } \\
\text { thus, eliminating the need for an internal standard. }\end{array}$ \\
\hline TYPICAL RESULTS & $\begin{array}{l}\text { Precision of } 3 \% \text { for solutions with } 0.001-5.0 \mu \mathrm{g} \mathrm{U} / \mathrm{g} \text { solution. } \\
\text { Accuracy of } 2 \% \text { for } 0.001-5.0 \mu \mathrm{U} / \mathrm{g} \text { solution }\end{array}$ \\
\hline SAMPLE SIZE & $\begin{array}{l}0.001-5.0 \mu \mathrm{g} \mathrm{U} / \mathrm{g} \text { solution } \\
\text { Detection limit is } 2 \times 10^{-5} \mu \mathrm{g}\end{array}$ \\
\hline SAMPLE TYPES & Low and trace level U solutions. \\
\hline ADVANTAGES & $\begin{array}{l}\text { Method is rapid and relatively simple. } \\
\text { Sensitive to low levels of } U \text {. } \\
\text { Generally directly applicable to solutions without separations. } \\
\text { Pu does not interfere. }\end{array}$ \\
\hline LIMITATIONS & $\begin{array}{l}\text { Uranium must be present as } \mathrm{U}(\mathrm{VI}) \text {. } \\
\text { Contamination with } \mathrm{U} \text { from reagents or sample treatments must be } \\
\text { carefully avoided. } \\
\text { Alcohols, halides, and oxidizable metals are strong quenching agents } \\
\text { which interfere with phosphorescence of uranium. } \\
\text { Other materials such as chromate may absorb at the same excitation } \\
\text { wavelength as uranium ( } 425 \mathrm{~nm}) \text {. } \\
\text { Suspended particles interfere with the normal decay curve of uranium } \\
\text { phosphorescence. }\end{array}$ \\
\hline REFERENCES & $\begin{array}{l}\text { W. Campen and K. Bachmann, "Laser-Induced Fluorescence for the } \\
\text { Direct Determination of Small Concentrations of Uranium in Water, " } \\
\text { Mikrochim. Acta [Wien], } 1979 \text { II, pp. 159-170. } \\
\text { A. C. Zook, L. H. Collins, and C. E. Pietri, "Determination of Nanogram } \\
\text { Quantities of Uranium by Pulsed-Laser Fluorimetry," Mikrochim. Acta } \\
\text { [Wien], } 1981 \text { II, pp. 457-468. }\end{array}$ \\
\hline COST ESTIMATE & LOW \\
\hline
\end{tabular}


Attachment 2

\section{Destructive Analysis Method Compendium}

Page 17 of 40

\begin{tabular}{|c|c|}
\hline \multicolumn{2}{|l|}{ Method A.2.5: Densitometry } \\
\hline Physical Property Measured & $\begin{array}{l}\text { Density in mass per volume. Very precise specific gravity values may be } \\
\text { calculated at specified temperatures from the measured density at } \\
\text { specified temperatures. }\end{array}$ \\
\hline BASIC PRINCIPLE & $\begin{array}{l}\text { A vibrating hollow U-shaped tube is caused to oscillate at a high } \\
\text { frequency. The frequency squared of the tube oscillation is proportional } \\
\text { to the mass of the tube. Filling the hollow tube with a liquid changes the } \\
\text { mass of the tube and the tube oscillation. The density meter is calibrated } \\
\text { by injection of two standards of different density into the hollow tube and } \\
\text { measuring the tube oscillation for each standard. The density of an } \\
\text { unknown sample is determined by relating the tube oscillation of the } \\
\text { sample to the tube oscillation of the standards. Temperature is } \\
\text { controlled either with a constant temperature bath or Peltier cooler. }\end{array}$ \\
\hline TYPICAL RESULTS & $\begin{array}{l}\text { Instrumentation is available that provides density values to four, five, or } \\
\text { six decimal places. }\end{array}$ \\
\hline SAMPLE SIZE & Approximately $1 \mathrm{ml}$. \\
\hline SAMPLE TYPES & $\begin{array}{l}\text { Any liquid that can be injected with a syringe and not vigorously attack } \\
\text { glass. Instruments are available that have stainless steel U tubes } \\
\text { instead of glass. }\end{array}$ \\
\hline ADVANTAGES & $\begin{array}{l}\text { Very fast analyses, easy to automate, data obtained in electronic format } \\
\text { and easy to transmit electronically. Very precise temperature control } \\
\text { (instrumentation easy to calibrate at various temperatures). Instruments } \\
\text { operate for years with minimal maintenance. }\end{array}$ \\
\hline LIMITATIONS & Suspended solids and air/gas bubbles can interfere. \\
\hline REFERENCES & $\begin{array}{l}\text { Calculating Density Meter with a built-in thermostat, DMA } 46 \text { Instruction } \\
\text { Manual, Anton Paar }{ }^{\mathrm{TM}} \text {, Graz/AUSTRIA. }\end{array}$ \\
\hline COST ESTIMATE & LOW \\
\hline
\end{tabular}


Attachment 2

Destructive Analysis Method Compendium

Page 18 of 40

\begin{tabular}{|c|c|}
\hline \multicolumn{2}{|c|}{ METHOD A.3.1: Mass Spectrometry: Isotopic Abundance of $U$ and $\mathrm{Pu}$} \\
\hline ELEMENT DETERMINED & $\mathrm{U} \& \mathrm{Pu}$ \\
\hline TYPICAL RESULTS & Random and systematic errors of $0.01-0.1 \%$ depending on sample size. \\
\hline BASIC PRINCIPLE & $\begin{array}{l}\text { Conversion of a sample to a gaseous, ionic form; separation of the ions } \\
\text { according to their mass to charge ratios in a magnetic field; and } \\
\text { measurement of the relative intensities of the separated ion beams. }\end{array}$ \\
\hline SAMPLE SIZE & $\begin{array}{l}U-10^{-8} \text { to } 10^{-5} \mathrm{~g} \\
\text { Pu }-10^{-9} \text { to } 10^{-6} \mathrm{~g}\end{array}$ \\
\hline SAMPLE TYPES & All U \& Pu materials - after separation \\
\hline ADVANTAGES & $\begin{array}{l}\text { Method gives essentially complete isotopic information over a wide range } \\
\text { of isotopes with good precision and accuracy. } \\
\text { Requires very little sample. } \\
\text { Instrumentation is readily automated. }\end{array}$ \\
\hline LIMITATIONS & $\begin{array}{l}\text { Complex, expensive instrument requires care in operation; mass } \\
\text { discrimination and nonlinearities require corrections. } \\
\text { Usually require separations due to problems from interferences and } \\
\text { impurities. }\end{array}$ \\
\hline REFERENCES & $\begin{array}{l}\text { "Thermal Ionization Mass Spectrometry of Uranium with } \\
\text { Electrodeposition as a Loading Technique", D.J. Rokop, et al., Anal. } \\
\text { Chem., } 54957 \text { (1982). } \\
\text { "High-precision Isotopic Analyses of Uranium and Plutonium by Total } \\
\text { Sample Volatilization and Signal Integration", E.L. Callis and R.M. } \\
\text { Abernathey, Int. J. Mass Spect. Ion Processes, } 103 \text { 93-105 (1991). }\end{array}$ \\
\hline COST ESTIMATE & $\mathrm{HIGH}$ \\
\hline
\end{tabular}


Attachment 2

\section{Destructive Analysis Method Compendium}

Page 19 of 40

\begin{tabular}{|c|c|}
\hline ELEMENT DETERMINED & $\mathrm{U} \& \mathrm{Pu}$ \\
\hline BASIC PRINCIPLE & $\begin{array}{l}\text { Variation of mass spectrometry involving addition of a known quantity of } \\
\text { enriched isotope (Spike) to the sample which allows calculation of the } \\
\text { elemental concentration from the measured isotopic ratios of the mixture, } \\
\text { the measured ratios of an unspiked sample, and the known isotopic } \\
\text { composition of the spike. }\end{array}$ \\
\hline TYPICAL RESULTS & Random and systematic errors of $0.25 \%$ \\
\hline SAMPLE SIZE & $\begin{array}{l}\mathrm{U}-10^{-8} \text { to } 10^{-5} \mathrm{~g} \\
\mathrm{Pu}-10^{-9} \text { to } 10^{-6} \mathrm{~g}\end{array}$ \\
\hline SAMPLE TYPES & All U \& Pu materials - subject to availability of Spike materials \\
\hline ADVANTAGES & $\begin{array}{l}\text { Method determines both isotopic composition and elemental } \\
\text { concentration. } \\
\text { Good precision and accuracy can be achieved. } \\
\text { Requires only small amounts of sample. }\end{array}$ \\
\hline LIMITATIONS & $\begin{array}{l}\text { Complex, expensive instrumentation. } \\
\text { Problems with attaining chemical and isotopic equilibration. } \\
\text { Inadequate separation of } \mathrm{U} \text { and } \mathrm{Pu} \text {. } \\
\text { Uncertainties in assay of spike solutions. } \\
\text { Weighing errors for the sample or spike. } \\
\text { Mass spectrometer operational errors. }\end{array}$ \\
\hline REFERENCES & $\begin{array}{l}\text { "The Determination of Plutonium by Mass Spectrometry Using a 242- } \\
\text { Plutonium Tracer," R. K. Webster, A. A. Smales, D. F. Dance, and L. J. } \\
\text { Slee, Anal. Chim. Acta } 24371-380 \text { (1961). } \\
\text { "The Application of Isotope Dilution Mass Spectrometry to the } \\
\text { Determination of Uranium and Plutonium in Nuclear Fuels," J. E. Rein } \\
\text { and C. F. Metz, in Analytical chemistry of Nuclear Fuels, Proc. Panel, } \\
\text { Vienna, July 13-17, 1970, (International Atomic Energy Agency, Vienna, } \\
\text { Austria, 1972), pp. } 97-109 . \\
\text { The Use of a Combined Internal Standard and Assay Spike for the } \\
\text { Isotope Dilution Mass Spectrometric Assay of Plutonium, D. W. } \\
\text { Crawford, M. A. Legel, M. I. Spaletto, and N. M. Trahey, NBL-318(a), pp. } \\
\text { 17-19, March 1988. } \\
\text { "Isotope Dilution Mass Spectrometry," K.G. Heumann, in Inorganic Mass } \\
\text { Spectrometry, edited by F. Adams, R. Gijbels, and R. Van Grieken. John } \\
\text { Wiley and Sons, New York, 1988, pp. 301-376. }\end{array}$ \\
\hline COST ESTIMATE & $\begin{array}{l}\text { LOW (assumes suitable mass spectrometer already available, a HIGH } \\
\text { cost item) }\end{array}$ \\
\hline
\end{tabular}


Attachment 2

Destructive Analysis Method Compendium

Page 20 of 40

\begin{tabular}{|c|c|}
\hline \multicolumn{2}{|c|}{ METHOD A.4.1: Spectrophotometry for iron } \\
\hline ELEMENT DETERMINED & $\mathrm{Fe}$ \\
\hline BASIC PRINCIPLE & $\begin{array}{l}\text { Iron is measured spectrophotometrically as the } \mathrm{Fe}(\mathrm{II}) \text { o-phenanthrolate } \\
\text { complex at a wavelength of } 508 \mathrm{~nm} \text { after removal of plutonium by oxalate } \\
\text { precipitation. The quantitiy of iron is calculated from the measured } \\
\text { absorbance and the absorbance per microgram of iron obtained for } \\
\text { prepared solutions having known iron contents. [Fe Standard prepared } \\
\text { from electrolytic iron or ferrous ammonium sulfate hexahydrate.] }\end{array}$ \\
\hline TYPICAL RESULTS & The relative standard deviation is approximately $1 \%$. \\
\hline SAMPLE SIZE & 10-40 micrograms Fe [capability to 1 microgram with wider precision]. \\
\hline SAMPLE TYPES & Iron in the range $100-1000 \mu \mathrm{g} \mathrm{Fe} \mathrm{per} \mathrm{gram} \mathrm{of} \mathrm{uranium-plutonium} \mathrm{oxide}$ \\
\hline ADVANTAGES & $\begin{array}{l}\text { Rapid and simple measurement to allow for iron correction of plutonium } \\
\text { results. } \\
\text { Typical elapsed time for analysis of } 3 \text { hours. }\end{array}$ \\
\hline LIMITATIONS & $\begin{array}{l}\text { If nickel is present in quantities greater than that of iron, it will produce a } \\
\text { bias in the iron measurement that is greater than } 1.5 \% \text {. }\end{array}$ \\
\hline REFERENCES & $\begin{array}{l}\text { Los Alamos National Laboratory Report, LA-4622, "Methods of Chemical } \\
\text { Analysis for FBR Uranium-Plutonium Oxide Fuel and Source Materials," } \\
\text { J. E. Rein, G. M. Matlack, G. R. Waterbury, R. T. Phelps, and C. F. Metz, } \\
\text { pp 55-58, (1971). }\end{array}$ \\
\hline COST ESTIMATE & LOW \\
\hline
\end{tabular}


Attachment 2

Destructive Analysis Method Compendium

Page 21 of 40

\begin{tabular}{|c|c|}
\hline ELEMENT DETERMINED & Metal impurities \\
\hline BASIC PRINCIPLE & $\begin{array}{l}\text { Powdered samples are loaded into graphite electrodes. A dc arc is } \\
\text { induced across the electrodes producing arc temperatures from } 4000 \text { to } \\
8000^{\circ} \mathrm{K} \text {. Emission lines from primarily neutral atoms are detected using } \\
\text { either photographic plates or photomultiplier tubes. Intensities of } \\
\text { emission lines are related to those of standards to obtain quantitative } \\
\text { information. }\end{array}$ \\
\hline TYPICAL RESULTS & $\begin{array}{l}\text { The technique is used to measure metal impurities in the range of } 0.1- \\
2000 \square \mathrm{g} / \mathrm{g} \text { (lower and upper limits are element specific). }\end{array}$ \\
\hline SAMPLE SIZE & $\begin{array}{l}\text { Electrodes are loaded with approximately } 50-\mathrm{mg} \text { of sample. Samples are } \\
\text { usually homogenized before loading electrodes. }\end{array}$ \\
\hline SAMPLE TYPES & All types of samples (must be solid to load into electrode) \\
\hline ADVANTAGES & $\begin{array}{l}\text { - Relatively low cost } \\
\text { - Large number of metal impurities detected simultaneously } \\
\text { - Almost any sample matrix can be analyzed }\end{array}$ \\
\hline LIMITATIONS & $\begin{array}{l}\text { - Relatively large error (better than spark source mass spectrometry but } \\
\text { worse than inductively coupled plasma optical emission) } \\
\text { - Susceptible to contamination (like any impurity analysis). } \\
\text { - Requires highly trained technician. }\end{array}$ \\
\hline REFERENCES & $\begin{array}{l}\text { H. H. Willard, L.L. Merritt, Jr., and J.A. Dean, Instrumental Methods of } \\
\text { Analysis, } 5^{\text {th }} \text { Ed., D. Van Nostrand, New York, 1974, p. } 390 .\end{array}$ \\
\hline COST ESTIMATE & Medium \\
\hline
\end{tabular}


Attachment 2

Destructive Analysis Method Compendium

Page 22 of 40

\begin{tabular}{|c|c|}
\hline ELEMENT DETERMINED & $\begin{array}{l}\text { Metallic sample components and isotopic composition when using ICP- } \\
\text { MS }\end{array}$ \\
\hline BASIC PRINCIPLE & $\begin{array}{l}\text { Detection mechanisms: } \\
\text { - AA: absorption of element-specific wavelengths } \\
\text { - ICP-OES: emission of element-specific wavelengths generated by the } \\
\text { inductively coupled plasma } \\
\text { - ICP-MS: ions generated in an inductively coupled plasma are mass } \\
\text { analyzed by one of several methods (e.g., quadrapole or magnetic sector } \\
\text { mass spectrometer). }\end{array}$ \\
\hline TYPICAL RESULTS & Typically, impurities can be determined from $1-5000$ ppm. \\
\hline SAMPLE SIZE & Depends on dilution factor (0.1-g or larger). \\
\hline SAMPLE TYPES & Liquids and solids (solids require dissolution). \\
\hline ADVANTAGES & $\begin{array}{l}\text { High precision } \\
\text { Wide dynamic range } \\
\text { Multiple element, simultaneous analyses (with the exception of } A A \text { ) }\end{array}$ \\
\hline LIMITATIONS & $\begin{array}{l}\text { Samples must be in solution } \\
\text { Requires highly skilled technicians } \\
\text { Subject to contamination }\end{array}$ \\
\hline REFERENCES & \\
\hline COST ESTIMATE & MEDIUM (except for AA which is LOW) \\
\hline
\end{tabular}


Attachment 2

\section{Destructive Analysis Method Compendium}

Page 23 of 40

\section{Appendix B. International Regulations and Guidelines.}

\section{Appendix B.1. Code of Federal Regulations (CFR)}

\section{CFR Part 70.51}

The limits of error on the material unaccounted for (MUF) on any total plant in-process MBA are:

1) $\mathrm{Pu}$ or ${ }^{233} \mathrm{U}$ in chemical reprocessing plant:

$1.0 \%$

2) $U$ elemental and fissile isotope in reprocessing plant:

$0.7 \%$

3) $\mathrm{Pu},{ }^{233} \mathrm{U}$, high-enriched $\mathrm{U}$ elemental and fissile isotope in all other:

$0.5 \%$

4) Low-enriched uranium element and fissile isotope in all other:

$$
0.5 \%
$$

\section{CFR Part 74.13}

A report to the Nuclear Regulatory Commission (NRC) is required if inventory difference exceeds both:

1) Twice the standard error of the estimated measurement uncertainty associated with the inventory difference; and

2) Two hundred grams of plutonium or ${ }^{233} U, 300$ grams of high enriched ${ }^{235} U$ contained in highenriched uranium, or 9000 grams of ${ }^{235} \mathrm{U}$ contained in low enriched uranium.

\section{Appendix B.2. International Atomic Energy Agency (IAEA) Guidance}

IAEA/SG/INF/4; "IAEA Safeguards Aims, Limitations, Achievements" IAEA, Vienna, 1983, p. 26

For direct-use material, the significant quantities (SQs) have been set to coincide in weight (though not exactly in composition) with threshold amounts:

1) $8 \mathrm{~kg}$ of plutonium element (containing less than $80 \%{ }^{238} \mathrm{Pu}$ )

2) $25 \mathrm{~kg}$ of ${ }^{235} \mathrm{U}$ contained in uranium enriched to $20 \%$ or more

3) $8 \mathrm{~kg}$ of ${ }^{233} \mathrm{U}$

\section{Appendix B.3. Target Values (US Department of Energy Guidance)}

Target Values for Tank Volume Measurements of Solutions using a Ruska Electromanometer

\begin{tabular}{|c|c|c|}
\hline & Precision & Bias \\
\hline Material/Type Element & \% Rel. Ran. Error & \% Rel. Sys. Error \\
\hline U Solutions/Pure Pu & 0.3 & 0.3 \\
\hline
\end{tabular}


Attachment 2

\section{Destructive Analysis Method Compendium}

Page 24 of 40

Appendix B.4. Target Values (Working Group on Techniques and Standards for Destructive Analysis (WGDA) of the European Safeguards Research and Development Association (ESARDA) ${ }^{2}$ )

\section{B.4.1 Target Values for Titrimetry Measurements for Process, Product, Scrap, and Waste} Materials

\begin{tabular}{|c|c|c|c|}
\hline Material/Type & Element & $\begin{array}{l}\text { Precision } \\
\text { \% Rel. Ran. Error }\end{array}$ & $\begin{array}{l}\text { Bias } \\
\% \text { Rel. Sys. Error }\end{array}$ \\
\hline $\mathrm{UF}_{6}$ & $U^{a}$ & $0.1^{3}$ & $0.1^{3}$ \\
\hline U Solutions/pure & $U$ & 0.15 & 0.15 \\
\hline U Solutions/scrap & $U^{b}$ & 0.3 & 0.5 \\
\hline U Oxide/powder, NG & $U^{c}$ & $0.1^{3}$ & $0.1^{3}$ \\
\hline U Oxide/powder, scrap & $U$ & 0.3 & 0.5 \\
\hline U Oxide/sintered materials & $U$ & 0.15 & 0.1 \\
\hline $\mathrm{UF}_{4}$ Powder/NG & $U^{c}$ & 0.15 & 0.3 \\
\hline U-metal/NG & $U$ & $0.2^{3}$ & $0.2^{3}$ \\
\hline U-Al based materials/NG & $U$ & 0.2 & 0.3 \\
\hline U-Al based/scrap & $U$ & 0.3 & 0.5 \\
\hline U-Si based materials/NG & $U$ & 0.2 & 0.3 \\
\hline Zr-U materials & $U$ & 0.5 & 0.3 \\
\hline U/Carbides & $U$ & 0.3 & 0.5 \\
\hline 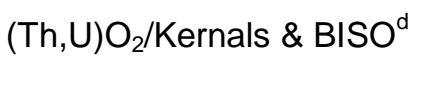 & $\begin{array}{l}U \\
T h\end{array}$ & $\begin{array}{l}0.15 \\
0.2\end{array}$ & $\begin{array}{l}0.2 \\
0.2\end{array}$ \\
\hline$(\mathrm{Th}, \mathrm{U}) \mathrm{O}_{2}$ or $\mathrm{UO}_{2} / \mathrm{TRISO}^{d}$ & $\begin{array}{l}U \\
\text { Th }\end{array}$ & $\begin{array}{l}0.2 \\
0.2\end{array}$ & $\begin{array}{l}0.2 \\
0.3\end{array}$ \\
\hline U-scrap/dirty \& diluted & $U$ & 0.5 & 2.0 \\
\hline
\end{tabular}

a Control of decomposition required if subjected to chemical decomposition.

b Shall be free of turbidity.

c Control of oxidation and/or moisture pickup required.

d BISO, TRISO: binary, trinary sealed oxide coated particles.

\footnotetext{
${ }^{2}$ P. De Bièvre, J. Dalton, S. Baumann, R. E. Perrin, T. Görgenyi, C. Pietri, E. Kuhn, and S. Deron, "1987 Target Values for the Uncertainty Components in Fissile Isotope and Element Assay," Journal of Nuclear Materials Management, pp. 99-106, July 1987.

${ }^{3}$ H. Aigner et al., " International Target Values 2000 for Measurement Uncertainties in Safeguarding Nuclear Material”, International Atomic Energy Agency Report, STR-327, Millennium Edition, April 2001.
} 


\section{Attachment 2 \\ Destructive Analysis Method Compendium \\ Page 25 of 40}

B.4.1 (continued) Target Values for Titrimetry Measurements for Process, Product, Scrap, and Waste Materials

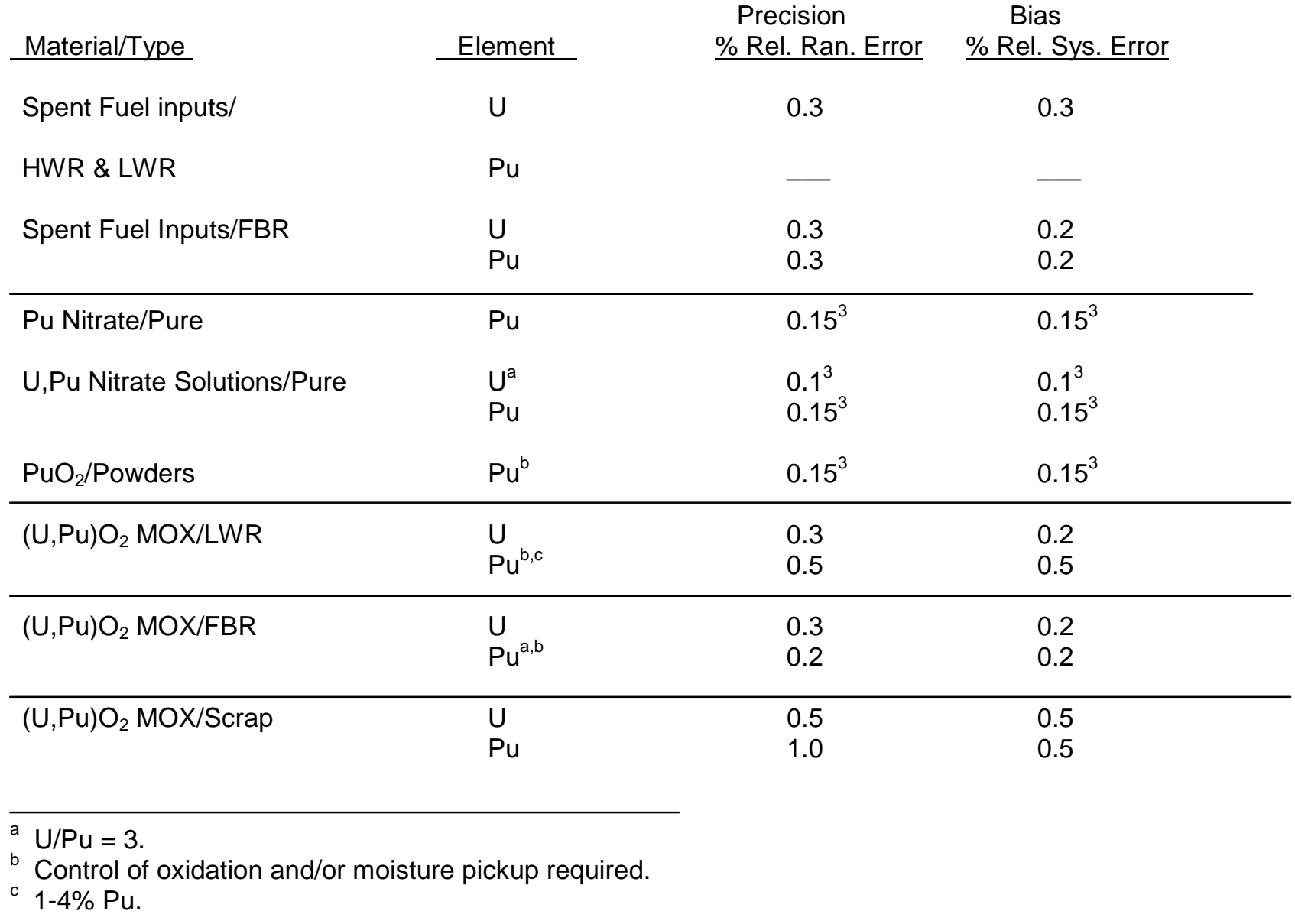

${ }^{3} \mathrm{H}$. Aigner et al., "International Target Values 2000 for Measurement Uncertainties in Safeguarding Nuclear Material”, International Atomic Energy Agency Report, STR-327, Millennium Edition, April 2001. 
Attachment 2

Destructive Analysis Method Compendium

Page 26 of 40

\section{B.4.2 Target Values for Coulometry Measurements for Process, Product, and Scrap Materials}

\begin{tabular}{|c|c|c|c|}
\hline Material/Type & Element & $\begin{array}{l}\text { Precision } \\
\text { \% Rel. Ran. Error }\end{array}$ & $\begin{array}{l}\text { Bias } \\
\text { \% Rel. Sys. Error }\end{array}$ \\
\hline $\mathrm{UF}_{6}$ & $U^{a}$ & 0.2 & 0.2 \\
\hline U Solutions/pure & $U$ & 0.15 & 0.15 \\
\hline U Oxide/powder, NG & $U^{b}$ & 0.15 & 0.15 \\
\hline U Oxide/powder, scrap & $U$ & 0.3 & 0.5 \\
\hline U Oxide/sintered materials & $U$ & 0.15 & 0.15 \\
\hline $\mathrm{UF}_{4}$ Powder/NG & $U^{b}$ & 0.15 & 0.3 \\
\hline U-metal/NG & $U$ & 0.15 & 0.1 \\
\hline U-Al based materials/NG & $U$ & 0.2 & 0.3 \\
\hline U-Al based/scrap & $U$ & 0.3 & 0.5 \\
\hline U/Carbides & $U$ & 0.3 & 0.5 \\
\hline Pu Nitrate/Pure & $\mathrm{Pu}$ & 0.2 & 0.2 \\
\hline $\begin{array}{l}\text { U,Pu Nitrate Solutions/Pure } \\
\mathrm{PuO}_{2} / \text { Powders }\end{array}$ & $\begin{array}{l}\mathrm{U}^{\mathrm{c}} \\
\mathrm{Pu} \\
\mathrm{Pu}^{\mathrm{b}}\end{array}$ & $\begin{array}{l}0.2 \\
0.2 \\
0.2\end{array}$ & $\begin{array}{l}0.2 \\
0.2 \\
0.2\end{array}$ \\
\hline$(\mathrm{U}, \mathrm{Pu}) \mathrm{O}_{2} \mathrm{MOX} / \mathrm{LWR}$ & $\begin{array}{l}\mathrm{U} \\
\mathrm{Pu}^{\mathrm{b}, \mathrm{d}}\end{array}$ & $\begin{array}{l}0.3 \\
0.5 \\
\end{array}$ & $\begin{array}{l}0.2 \\
0.5 \\
\end{array}$ \\
\hline$(\mathrm{U}, \mathrm{Pu}) \mathrm{O}_{2} \mathrm{MOX} / \mathrm{FBR}$ & $\begin{array}{l}\cup \\
\mathrm{Pu}^{\mathrm{b}, \mathrm{c}}\end{array}$ & $\begin{array}{l}0.3 \\
0.2\end{array}$ & $\begin{array}{l}0.2 \\
0.2\end{array}$ \\
\hline$(\mathrm{U}, \mathrm{Pu}) \mathrm{O}_{2} \mathrm{MOX} / \mathrm{Scrap}$ & $\begin{array}{l}\mathrm{U} \\
\mathrm{Pu}\end{array}$ & $\begin{array}{l}0.5 \\
1.0\end{array}$ & $\begin{array}{l}0.5 \\
0.5\end{array}$ \\
\hline
\end{tabular}

${ }^{\text {a }}$ Control of decomposition required if subjected to chemical decomposition.

b Control of oxidation and/or moisture pickup required.

${ }^{c} \mathrm{U} / \mathrm{Pu}=3$.

d $1-4 \% \mathrm{Pu}$. 
Attachment 2

Destructive Analysis Method Compendium

Page 27 of 40

\section{B.4.3 Target Values for Gravimetry Measurements for Process and Product Materials}

\begin{tabular}{|c|c|c|c|}
\hline Material/Type & Element & $\begin{array}{l}\text { Precision } \\
\text { \% Rel. Ran. Error }\end{array}$ & $\begin{array}{l}\text { Bias } \\
\% \text { Rel. Sys. Error }\end{array}$ \\
\hline $\mathrm{UF}_{6}$ & $U^{a}$ & $0.05^{3}$ & $0.05^{3}$ \\
\hline U Solutions/pure & $U$ & 0.1 & 0.15 \\
\hline U Oxide/powder, NG & $U^{b}$ & $0.05^{3}$ & $0.05^{3}$ \\
\hline U Oxide/sintered materials & $U$ & 0.05 & 0.1 \\
\hline $\mathrm{UF}_{4}$ Powder/NG & $\mathrm{U}^{\mathrm{b}}$ & 0.15 & 0.15 \\
\hline U/Carbides & $U$ & 0.2 & 0.5 \\
\hline Pu Nitrate/Pure & $\mathrm{Pu}$ & 0.1 & 0.15 \\
\hline $\mathrm{PuO}_{2} /$ Powders & $\mathrm{Pu}^{\mathrm{b}}$ & $0.05^{3}$ & $0.05^{3}$ \\
\hline$(\mathrm{U}, \mathrm{Pu}) \mathrm{O}_{2} \mathrm{MOX} / \mathrm{LWR}$ & $\begin{array}{l}U^{c} \\
\mathrm{Pu}\end{array}$ & $\begin{array}{l}0.1 \\
---\end{array}$ & $\begin{array}{l}0.15 \\
---\end{array}$ \\
\hline
\end{tabular}

a Control of decomposition required if subjected to chemical decomposition.

b Control of oxidation and/or moisture pickup required.

${ }^{c}$ After Pu and Am correction. 
Attachment 2

Destructive Analysis Method Compendium

Page 28 of 40

B.4.4 Target Values for K-edge Densitometry Measurements for Process, Scrap, and Waste Materials

\begin{tabular}{lcccc} 
Material/Type & Element & & $\begin{array}{c}\text { Precision } \\
\text { \% Rel. Ran. Error }\end{array}$ & $\begin{array}{c}\text { Bias } \\
\text { \% Rel. Sys. Error }\end{array}$ \\
\cline { 2 - 3 } U Solutions/pure & $U$ & 0.2 & $0.15^{3}$ \\
U Solutions/scrap & $U^{\mathrm{a}}$ & & 0.2 & 0.2 \\
\hline Pu Nitrate/Pure & $\mathrm{Pu}$ & 0.2 & $0.15^{3}$ \\
U,Pu Nitrate Solutions/Pure & $\mathrm{U}^{\mathrm{b}}$ & $\mathrm{Pu}$ & 0.2 & 0.2 \\
& $\mathrm{U}$ & 0.3 & 0.3 \\
U,Pu Solutions/Waste & $\mathrm{Pu}$ & 0.3 & 0.3
\end{tabular}

a Shall be free of turbidity.

${ }^{\mathrm{b}} \mathrm{U} / \mathrm{Pu}=3$.

${ }^{3} \mathrm{H}$. Aigner et al., "International Target Values 2000 for Measurement Uncertainties in Safeguarding Nuclear Material", International Atomic Energy Agency Report, STR-327, Millennium Edition, April 2001. 
Attachment 2

Destructive Analysis Method Compendium

Page 29 of 40

\begin{tabular}{|c|c|c|c|}
\hline Material/Type & Element & $\begin{array}{l}\text { Precision } \\
\text { \% Rel. Ran. Error }\end{array}$ & $\begin{array}{l}\quad \text { Bias } \\
\% \text { Rel. Sys. Error } \\
\end{array}$ \\
\hline U Solutions/pure & $U$ & 0.5 & 0.5 \\
\hline U Solutions/scrap & $U^{a}$ & 2.0 & 2.0 \\
\hline U Oxide/powder, scrap & U & 1.0 & 1.0 \\
\hline $\mathrm{Zr}-\mathrm{U}$ materials & $U$ & 1.0 & 1.0 \\
\hline$(\mathrm{Th}, \mathrm{U}) \mathrm{O}_{2} /$ kernals \& $\mathrm{BISO}^{\mathrm{b}}$ & $\begin{array}{l}\text { U } \\
\text { Th }\end{array}$ & $\begin{array}{l}1.0 \\
1.0\end{array}$ & $\begin{array}{l}0.5 \\
0.5\end{array}$ \\
\hline$(\mathrm{Th}, \mathrm{U}) \mathrm{O}_{2}$ or $\mathrm{UO}_{2} / \mathrm{TRISO}^{\mathrm{b}}$ & $\begin{array}{l}U \\
\text { Th }\end{array}$ & $\begin{array}{l}1.0 \\
1.0\end{array}$ & $\begin{array}{l}1.0 \\
1.0\end{array}$ \\
\hline U-scrap/dirty \& diluted & $U$ & 3.0 & 5.0 \\
\hline $\begin{array}{l}\text { Spent Fuel inputs/ } \\
\text { HWR \& LWR }\end{array}$ & $\begin{array}{l}\mathrm{U} \\
\mathrm{Pu}\end{array}$ & $\begin{array}{l}0.5 \\
1.0\end{array}$ & $\begin{array}{l}0.5 \\
1.0_{-}\end{array}$ \\
\hline Spent Fuel Inputs/FBR & $\begin{array}{l}\mathrm{U} \\
\mathrm{Pu}\end{array}$ & $\begin{array}{l}0.5 \\
1.0\end{array}$ & $\begin{array}{l}0.5 \\
1.0\end{array}$ \\
\hline Liquid Waste/HAW & $\mathrm{Pu}$ & 5.0 & 10.0 \\
\hline Pu Nitrate/Pure & $\mathrm{Pu}$ & 0.5 & 0.5 \\
\hline U,Pu Nitrate Solutions/Pure & $\begin{array}{l}U^{c} \\
\mathrm{Pu}\end{array}$ & $\begin{array}{l}0.5 \\
0.5\end{array}$ & $\begin{array}{l}0.5 \\
0.5\end{array}$ \\
\hline U,Pu Solutions/Waste & $\begin{array}{l}\mathrm{U} \\
\mathrm{Pu}\end{array}$ & $\begin{array}{l}3.0 \\
3.0\end{array}$ & $\begin{array}{l}5.0 \\
5.0\end{array}$ \\
\hline$(\mathrm{U}, \mathrm{Pu}) \mathrm{O}_{2} \mathrm{MOX} / \mathrm{FBR}$ & $\begin{array}{l}\mathrm{U} \\
\mathrm{Pu}^{\mathrm{c}, \mathrm{d}} \\
\end{array}$ & $\begin{array}{l}0.5 \\
0.5 \\
\end{array}$ & $\begin{array}{l}0.5 \\
0.5 \\
\end{array}$ \\
\hline$(\mathrm{U}, \mathrm{Pu}) \mathrm{O}_{2} \mathrm{MOX} / \mathrm{Scrap}$ & $\begin{array}{l}\mathrm{U} \\
\mathrm{Pu}\end{array}$ & $\begin{array}{l}3.0 \\
3.0\end{array}$ & $\begin{array}{l}5.0 \\
5.0\end{array}$ \\
\hline $\begin{array}{ll}\text { a } & \text { Shall be free of turbidity. } \\
\text { b } & \text { BISO, TRISO: binary, trina } \\
c & \mathrm{U} / \mathrm{Pu}=3 . \\
\text { d } & \text { Control of oxidation and/or }\end{array}$ & $\begin{array}{l}\text { oxide co } \\
\text { ickup re }\end{array}$ & & \\
\hline
\end{tabular}


Attachment 2

Destructive Analysis Method Compendium

Page 30 of 40

\begin{tabular}{|c|c|c|c|}
\hline Material/Type & Element & $\begin{array}{l}\text { Precision } \\
\text { \% Rel. Ran. Error } \\
\end{array}$ & $\begin{aligned} & \text { Bias } \\
& \% \text { Rel. Sys. Error }\end{aligned}$ \\
\hline U Solutions/scrap & $U^{a}$ & 3.0 & 5.0 \\
\hline U-scrap/dirty \& diluted & $U$ & 5.0 & 10 \\
\hline $\begin{array}{l}\text { Spent Fuel inputs/ } \\
\text { HWR \& LWR }\end{array}$ & $\begin{array}{l}\mathrm{U} \\
\mathrm{Pu}\end{array}$ & $\begin{array}{l}-- \\
1.0\end{array}$ & $\begin{array}{l}--- \\
1.0\end{array}$ \\
\hline Spent Fuel Inputs/FBR & $\begin{array}{l}\mathrm{U} \\
\mathrm{Pu}\end{array}$ & $\overline{1 .-}$ & $\overline{---}$ \\
\hline Pu Nitrate/Pure & $\mathrm{Pu}$ & 0.5 & 0.5 \\
\hline U,Pu Nitrate Solutions/Pure & $\begin{array}{l}\mathrm{U} \\
\mathrm{Pu}\end{array}$ & $\begin{array}{l}--- \\
0.5\end{array}$ & $\overline{0.5}$ \\
\hline U,Pu Solutions/Waste & $\begin{array}{l}\mathrm{U} \\
\mathrm{Pu}\end{array}$ & $\begin{array}{l}5.0 \\
2.0\end{array}$ & $\begin{array}{l}5.0 \\
2.0\end{array}$ \\
\hline $\mathrm{PuO}_{2} /$ Powders & $\mathrm{Pu}^{\mathrm{b}}$ & 0.5 & 0.5 \\
\hline$(\mathrm{U}, \mathrm{Pu}) \mathrm{O}_{2} \mathrm{MOX} / \mathrm{LWR}$ & $\begin{array}{l}\mathrm{U} \\
\mathrm{Pu}^{\mathrm{b}, \mathrm{c}}\end{array}$ & 0.5 & 0.5 \\
\hline$(\mathrm{U}, \mathrm{Pu}) \mathrm{O}_{2} \mathrm{MOX} / \mathrm{FBR}$ & $\begin{array}{l}\mathrm{U}^{\mathrm{b}, \mathrm{d}} \\
\mathrm{Pu}\end{array}$ & 0.5 & 0.5 \\
\hline$(\mathrm{U}, \mathrm{Pu}) \mathrm{O}_{2} \mathrm{MOX} / \mathrm{Scrap}$ & $\begin{array}{l}\mathrm{U} \\
\mathrm{Pu}\end{array}$ & $\overline{---}$ & $\overline{---}$ \\
\hline 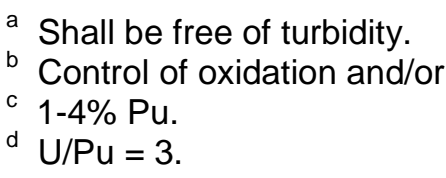 & pickup re & & \\
\hline
\end{tabular}

\section{B.4.7 Target Values for Fluorimetry Measurements for Scrap Materials}

\begin{tabular}{|c|c|c|c|}
\hline Material/Type & Element & $\begin{array}{l}\text { Precision } \\
\% \text { Rel. Ran. Error }\end{array}$ & $\begin{array}{l}\text { Bias } \\
\% \text { Rel. Sys. Error }\end{array}$ \\
\hline U Solutions/scrap & $U^{a}$ & 10 & 10 \\
\hline U Scrap/dirty \& diluted & U & 10 & 10 \\
\hline
\end{tabular}


Attachment 2

Destructive Analysis Method Compendium

Page 31 of 40

B.4.8 Target Values for Alpha Counting Measurements for Waste Materials

\begin{tabular}{lll} 
& Precision & Bias \\
Material/Type & Element & \% Rel. Ran. Error $\%$ Rel. Sys. Error \\
\cline { 2 - 4 }
\end{tabular}

\begin{tabular}{cccc} 
Liquid Waste/HAW & $\mathrm{Pu}$ & 10 & 10 \\
/MAW & $\mathrm{Pu}$ & 5 & 5 \\
/LAW & $\mathrm{Pu}$ & 5 & 5 \\
\hline U,Pu Solutions/Waste & $\mathrm{U}$ & 5 & 5
\end{tabular}

B.4.9 Target Values for IDMS Measurements for Process, Product, and Waste Materials

\begin{tabular}{lcccc} 
Material/Type & Element & & $\begin{array}{c}\text { Precision } \\
\text { \% Rel. Ran. Error }\end{array}$ & $\begin{array}{c}\text { Bias } \\
\text { \% Rel. Sys. Error }\end{array}$ \\
\cline { 2 - 3 } Spent Fuel inputs/ & $\mathrm{U}$ & 0.5 & 0.5 \\
HWR \& LWR & $\mathrm{Pu}$ & 0.5 & 0.5 \\
Spent Fuel Inputs/FBR & $\mathrm{U}$ & 0.5 & 0.5 \\
& $\mathrm{Pu}$ & 0.5 & 0.5 \\
\hline U,Pu Solutions/Waste & $\mathrm{U}$ & 0.5 & 0.5 \\
& $\mathrm{Pu}$ & 0.5 & 0.5
\end{tabular}


Attachment 2

Destructive Analysis Method Compendium

Page 32 of 40

\section{B.4.10 TARGET VALUES FOR UNCERTAINTY COMPONENTS IN ISOTOPIC ASSAY}

\begin{tabular}{|c|c|c|c|c|c|c|c|c|c|c|c|}
\hline \multirow{2}{*}{ Isotope } & \multirow{2}{*}{$\begin{array}{l}\text { (\%) } \\
\text { Abund. }\end{array}$} & \multicolumn{2}{|c|}{$\mathrm{GMS}^{\mathrm{a}}$} & \multicolumn{2}{|c|}{ TIMS $^{b}$} & \multicolumn{2}{|c|}{$\begin{array}{l}\text { Gamma } \\
\text { Spec. }^{c}\end{array}$} & \multicolumn{2}{|c|}{$\begin{array}{l}\text { Alpha } \\
\text { Spec. }\end{array}$} & \multicolumn{2}{|c|}{ IDMS $^{d}$} \\
\hline & & Prec. $^{\mathrm{h}}$ & Bias $^{i}$ & Prec. & Bias & Prec & Bias & $\underline{\text { Prec }}$ & Bias & $\underline{\text { Prec }}$ & Bias \\
\hline${ }^{235} U$ & $\begin{array}{c}0.2^{\mathrm{e}} \\
0.7^{\mathrm{e}} \\
3^{\mathrm{e}} \\
20^{\dagger} \\
90^{\dagger}\end{array}$ & $\begin{array}{l}0.1 \\
0.05 \\
0.03 \\
0.02 \\
0.01\end{array}$ & $\begin{array}{l}0.1 \\
0.1 \\
0.1 \\
0.1 \\
0.03\end{array}$ & $\begin{array}{l}0.7 \\
0.5 \\
0.3 \\
0.1 \\
0.05\end{array}$ & $\begin{array}{l}0.5 \\
0.5 \\
0.3 \\
0.1 \\
0.05\end{array}$ & $\begin{array}{l}5 \\
2 \\
0.5 \\
0.5 \\
0.2\end{array}$ & $\begin{array}{c}3 \\
1 \\
0.5 \\
0.5 \\
0.5\end{array}$ & $\begin{array}{l}-- \\
-- \\
-- \\
-- \\
--\end{array}$ & $\begin{array}{l}-- \\
-- \\
-- \\
-- \\
--\end{array}$ & $\begin{array}{l}0.5 \\
0.5 \\
0.5 \\
0.5 \\
0.5\end{array}$ & $\begin{array}{l}0.5 \\
0.5 \\
0.5 \\
0.5 \\
0.5\end{array}$ \\
\hline${ }^{238} \mathrm{Pu}$ & $\begin{array}{l}0.3^{\mathrm{g}} \\
1.5^{\mathrm{g}}\end{array}$ & $\begin{array}{l}--- \\
---\end{array}$ & $\begin{array}{l}--- \\
---\end{array}$ & $\begin{array}{l}2 \\
0.7\end{array}$ & $\begin{array}{c}2 \\
0.7\end{array}$ & $\begin{array}{l}-- \\
--\end{array}$ & $\begin{array}{l}-- \\
--\end{array}$ & $\begin{array}{l}2 \\
3\end{array}$ & $\begin{array}{l}2 \\
2\end{array}$ & $\begin{array}{l}-- \\
--\end{array}$ & -- \\
\hline${ }^{239} \mathrm{Pu}$ & $50-80^{9}$ & --- & --- & 0.1 & 0.1 & -- & -- & -- & -- & 0.3 & 0.3 \\
\hline${ }^{240} \mathrm{Pu}$ & $10-30^{g}$ & --- & --- & 0.2 & 0.2 & -- & -- & -- & -- & -- & -- \\
\hline${ }^{241} \mathrm{Pu}$ & $\begin{array}{c}3^{g} \\
15^{g}\end{array}$ & --- & --- & $\begin{array}{l}0.3 \\
0.3\end{array}$ & $\begin{array}{l}0.3 \\
0.3\end{array}$ & $\begin{array}{l}-- \\
--\end{array}$ & $\begin{array}{l}-- \\
--\end{array}$ & $\begin{array}{l}-- \\
--\end{array}$ & $\begin{array}{l}-- \\
--\end{array}$ & $\begin{array}{l}0.3 \\
0.3\end{array}$ & $\begin{array}{l}0.3 \\
0.3\end{array}$ \\
\hline${ }^{242} \mathrm{Pu}$ & $1-5^{g}$ & --- & --- & 0.3 & 0.3 & -- & -- & -- & -- & -- & -- \\
\hline
\end{tabular}

a Gas isotope mass spectrometry $\left(\mathrm{UF}_{6}\right)$.

b Thermal ionization mass spectrometry.

c Only for materials free of ${ }^{232} U\left({ }^{232} U{ }^{235} U<10^{-9}\right)$.

d Isotope dilution mass spectrometry. Direct assay of isotope against spike, e.g. ${ }^{233} \mathrm{U}$.

e All materials.

$f$ Pure uranium compounds.

$g$ Pure Pu materials.

h \% Relative Random Error

i \% Relative Systematic Error 
Attachment 2

Destructive Analysis Method Compendium

Page 33 of 40

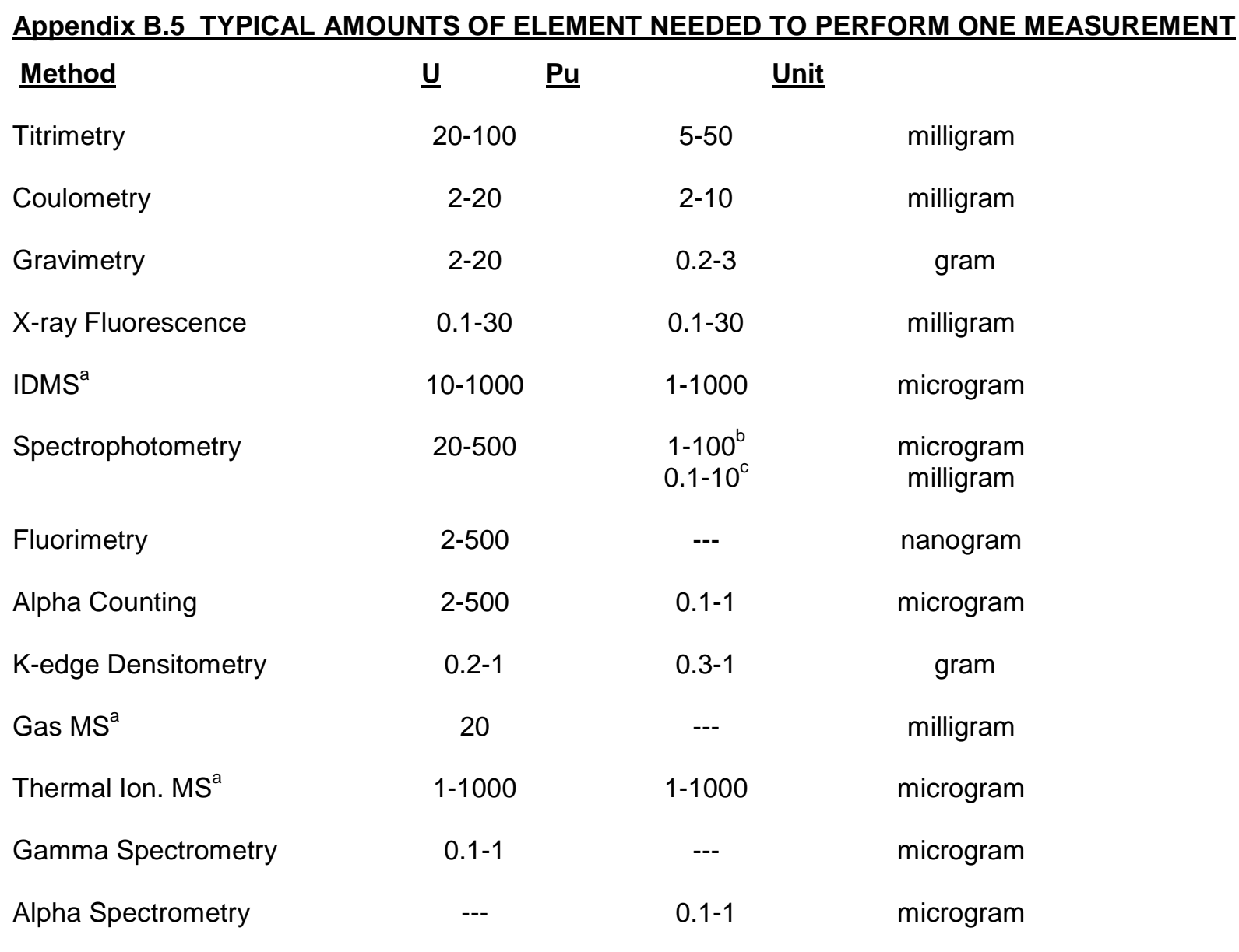

a Amount of sample required. In these cases an analysis can be performed on smaller amounts of element.

b Colorimetry

c Direct measurement at $830 \mathrm{~nm}$ of $\mathrm{Pu}(\mathrm{VI})$. 


\begin{tabular}{lll} 
Applicability of International and DOE Target Values & Technical Report:N-TRT-F-00001 \\
to ALD Destructive Measurement Applications (U) & Page 97 of 117 & Rev.0 \\
\hline
\end{tabular}

\author{
Attachment 2 \\ Destructive Analysis Method Compendium \\ Page 34 of 40
}

\begin{abstract}
APPENDIX C: An Example of Using an MBA Inventory Difference Limit to Estimate Uncertainty Criteria for Destructive Assay Measurements
\end{abstract}

Introduction. The question of how "good" do analytical chemistry measurement need to be to meet safeguards goals can be estimated by evaluating all measurements performed for a material balance area (MBA). To begin this process, one must first establish a goal-quantity for detection of theft. One criteria for making this goal-quantity is the IAEA "Significant Quantity" of $8 \mathrm{~kg}$ Pu and $25 \mathrm{Kg}^{235} \mathrm{U}$. These significant quantities are probably for inventory differences (ID) of entire sites and too large for a single MBA in a facility. A more realistic goal-quantity is the US DOE criterion of $2 \%$ of the MBA throughput. The most restrictive criteria is that of the US NRC allowable IDs. They are typically $<1 \%$ of throughput for $U$ and $<0.5 \%$ for $\mathrm{Pu}$.

Estimation Procedure. The steps one may follow to estimate the material measurement uncertainties required for theft detection are:

1. Determine the MBAs for the facility.

2. Establish the safeguards goal-quantity for the MBA and the statistical tests and degree of confidence to be associated with the detection of an inventory difference.

3. Determine the inventory period (monthly, bimonthly, etc.) for each MBA.

4. Determine the quantity and type of special nuclear material (SNM) stored in or processed in each MBA.

5. Establish key measurement points (KMP) for each MBA.

6. Identify the destructive analysis (DA) and non-destructive analysis (NDA) measurements to be used for SNM control (or process control or QA) for each MBA.

7. Make a chart or table showing the quantities of SNM, which will be measured at each KMP for each inventory period and the uncertainties, systematic and random, for each measurement method. These uncertainties may be estimated or, in the case of this example, the DA uncertainties left as unknowns to be determined. In addition to measurement errors, uncertainties should include all known sources of variation such as sampling errors, moisture uptake, and temperature and pressure effects.

8. Calculate the measurement uncertainties for each inventory period's SNM flow and beginning and ending inventories.

9. Combine these uncertainties and subtract the combined uncertainties from the total allowable uncertainty for theft detection. The difference will be the uncertainty "budgeted" for DA.

10. From this DA uncertainty 'budget', calculate the target uncertainty values for the DA methods.

This process is involved and material flows may not be well known at the beginning or NDA measurement uncertainties may not be well known. However, the factors that do not contribute much to the overall uncertainty can be roughly estimated. If 'conservative or somewhat overstated' estimates are made for the critical parameters, the final result will be a 'worst case' estimate. Often such an estimate is adequate for making DA upgrades decisions.

The outcome of such analyses will differ widely with the nature of the MBA and the confidence level desired for the detection of a diversion. For instance the acceptable random error for a measurement will be quite different depending on whether it is a single measurement of a large quantity of material or measurements on a large number of objects. For this appendix, a specific example has been selected and the parameters varied to show their relative effect. The reader is reminded that the following discussion is only an example and should not be considered as typical or representative of a real situation. It is particularly important to note that the statistical treatment used has been simplified. 


\section{Attachment 2 \\ Destructive Analysis Method Compendium Page 35 of 40}

Estimation Example. Consider the case of a MOX reactor fuel production facility that uses low burnup $\mathrm{Pu}$ and natural uranium oxides to make fuel pellets. A flow diagram for this facility is shown in Figure 1.

MOX Fuel Fabrication Facility

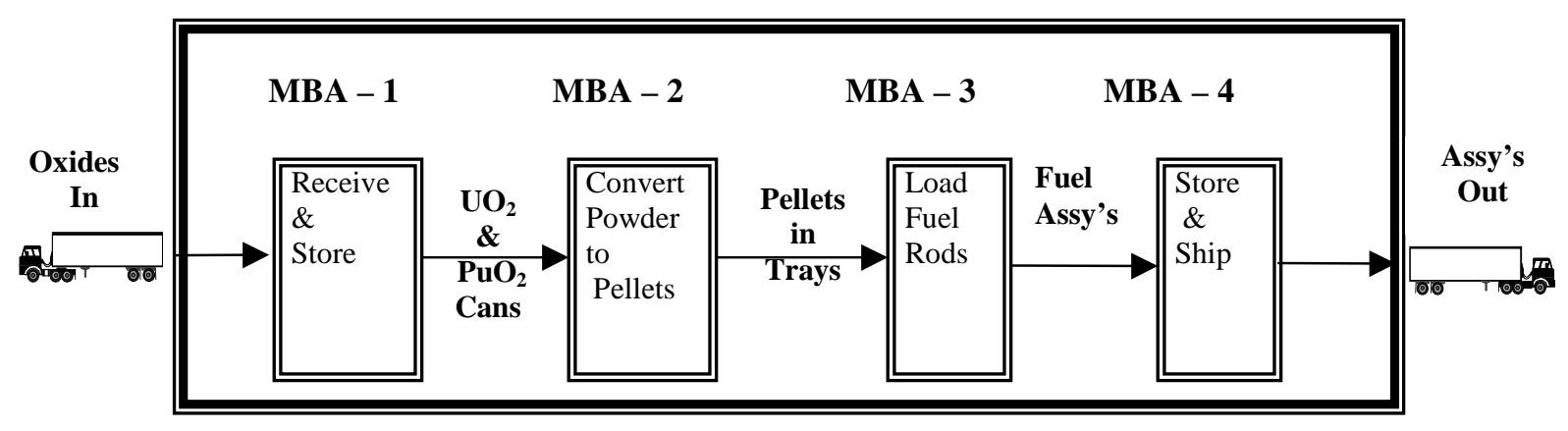

Figure 1

Step 1: Defining MBA's is outside the goal of this exercise. Take them as given in Figure 1.

Step 2: For this example only MBA-2, where oxide powder is converted to pellets, will be considered. The DOE $2 \%$-of-throughput criterion will be used. Having identified the goal-quantity, one must decide on the statistical tests to be used to identify whether observed IDs are "real". In addition IDs that are less than the goal-quantity, would be used to identify significant problems with the system. Confidence levels for both "false positives" and "false negatives" should also be established. These issues are beyond the scope of this appendix. The reader should consult statistical texts such as references ${ }^{3}-6$ for more details on this subject. For this exercise, the statistical significance of the uncertainties associated with measurements at the various parts of the process will not be specified. For a real situation, one must make a determination of the desired level of confidence required before identifying an inventory difference as such. To increase confidence that differences are "real", "wider" errors would be used. Unfortunately while decreasing the number of "false positives", this increases the chances of "false negatives"; ie, not detecting diversions. In order to detect a goal-quantity ID, the total error "budget" for measurements, including DA, must be less than the goal-quantity. For this example, the error budget will be taken as one half to the goal-quantity The relationships among bias, precision, and number of samples will be illustrated.

Step 3: Accountancy will be monthly.

\footnotetext{
${ }^{3}$ M. G. Natrella, Experimental Statistics: Handbook 91, U.S. Government Printing Office, Washington, 1963.

${ }^{5}$ Guide to the Expression of Uncertainty in Measurement, ISO/TAG4/WG3, June 1992.

${ }^{6}$ Evaluation and Control of Inventory Differences in the DOE Complex, TSO-87-9/BNL-40221, J. Sanborn, August 1987.
} 


\section{Attachment 2 \\ Destructive Analysis Method Compendium Page 36 of 40}

Step 4: Because the facility uses natural uranium (not an SNM), uranium can be ignored. Only Pu needs to be considered. Assume the "beginning inventory" is the same as the ending inventory for the prior month and consists of one input can containing $2 \mathrm{~kg}$ of $\mathrm{Pu}$ as $\mathrm{PuO}_{2}$ plus one tray of MOX pellets containing $1.9 \mathrm{~kg} \mathrm{Pu}$. All scrap is removed from the MBA before the ending inventory, i.e. the MBA is cleaned out between inventories. Assume holdup is measured annually, and does not contribute significantly to a single month ID. Finally assume the end of month inventory is the same as the beginning inventory. During the month the material flowed as follows: "N" new cans of Pu oxide each containing $2 \mathrm{~kg}$ Pu entered the process and the oxide was converted into MOX pellets; $\mathrm{N}$ trays of MOX pellets, each containing $1.9 \mathrm{~kg} \mathrm{Pu}$, exited the process. The balance of the material $(5 \%$ or $0.1 \mathrm{~kg}$ $\mathrm{Pu} / \mathrm{can})$ was in the form of scrap powder. Defining throughput as the sum of inputs and outputs from the MBA, the throughput was $2 \mathrm{~N} \mathrm{~kg}$ of Pu. Based on the $2 \%$ of throughput criteria for a theft-detection goalquantity, the MBA 2 goal-quantity is $2 \%$ of $2 \mathrm{~N} \mathrm{~kg} \mathrm{Pu}$. The value of $\mathrm{N}$ will be allowed to vary to illustrate the effect of the number of items on permissible uncertainties.

Step 5: Within MBA-2 samples will be taken for assay of both incoming and outgoing material. Figure 2 illustrates this MBA's SNM flows and locations of KMPs with their associated measurement methods.

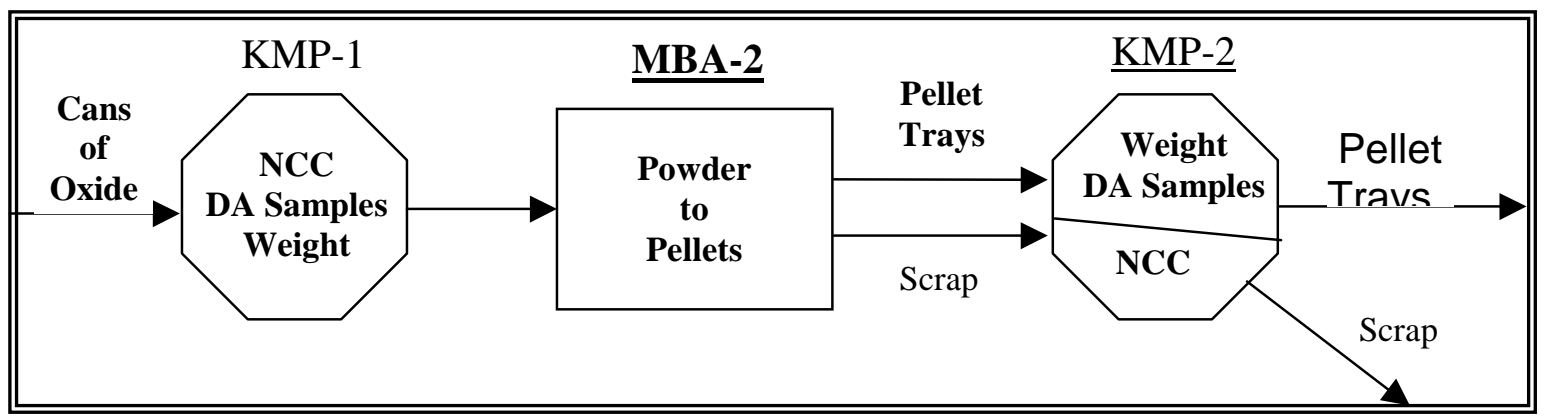

Figure 2, Key Measurement Points in MBA-2

Step 6: The measurements applied to the inventories and material flows are as follows:

The $\mathrm{PuO}_{2}$ can "passport" (shipper) values are used until the cans arrive at KMP-1.

Upon receipt at KMP-1, incoming cans are measured by neutron coincidence counting (NCC) and gamma spectroscopy to confirm the passport values The cans are then weighed and sampled. The samples are submitted for Pu assay by DA techniques.

Before leaving the MBA through KMP-2, MOX pellets in trays are weighed and samples taken for DA. Confirmatory measurements by NCC and gamma spectroscopy may also be made.

Scrap; i.e., oxide powder spilled or otherwise not successfully converted to pellets, is collected, weighed, and measured by NCC. This is also done at KMP-2. 
Attachment 2

\section{Destructive Analysis Method Compendium}

Page 37 of 40

Step 7: Table 1 summarizes the quantities of SNM, the measurement methods and systematic (bias) and measurement (random) uncertainties. . Because this exercise is to evaluate the permissible DA uncertainties, approximate weighing and NDA measurement uncertainties have been assigned without further justification. "TBD" means "To Be Determined." In this example, errors associated with sampling the powder and the pellets may be thought of as included in the errors of the measurement method. In a more realistic case, the sampling errors and statistical methods of sampling should be treated explicitly.

Table 1. Summary of Material Quantity, Measurements and Measurement Uncertainty Data

\begin{tabular}{|c|l|l|c|c|}
\hline KMP \# & $\begin{array}{l}\text { Material Form and } \\
\text { Pu mass, kg } \\
\mathrm{PuO}_{2} \text { powder cans } \\
2 \mathrm{~kg} / \mathrm{can}\end{array}$ & $\begin{array}{c}\text { Measurement } \\
\text { Method }\end{array}$ & $\begin{array}{l}\text { Weight } \\
\text { (Systematic } \\
\text { uncertainty, \%) }\end{array}$ & $\begin{array}{l}\text { Bias } \\
\text { (Randocision } \\
\text { uncertainty, \%) }\end{array}$ \\
\hline 1 & $\begin{array}{l}\mathrm{PuO_{2 }} \text { powder } \\
\text { samples }\end{array}$ & DA & $0.1 \%$ \\
\hline 1 & $\begin{array}{l}\mathrm{PuO} \text { powder cans, } \\
2 \mathrm{~kg} / \text { can }\end{array}$ & $\begin{array}{l}\text { NCC + gamma } \\
\text { Spectroscopy }\end{array}$ & confirmatory & confirmatory \\
\hline 2 & $\begin{array}{l}\text { ScrapU/Pu oxide can } \\
5 \% \text { of total Pu }\end{array}$ & NCC & $5 \%$ & $2 \%$ \\
\hline 2 & $\begin{array}{l}\text { MOX Pellets in trays } \\
\text { SCC + gamma }\end{array}$ & confirmatory & confirmatory \\
\hline 2 & MOX Pellet Samples & DA & TBD & TBD \\
\hline 2 & MOX Pellets in trays & Weight & $0.5 \%$ & $0.2 \%$ \\
\hline
\end{tabular}

Step 8: Calculate the uncertainties for the mass of Pu flowing through MBA-2 over the 1 month period and for the mass of Pu present in the beginning and ending inventory.

Tables 2 and 3 show the uncertainties, expressed as Pu mass, for the beginning and ending inventories and monthly throughput, respectively. The exact method for combining uncertainties can be complex. For a first approximation, one can add the systematic errors linearly and the random errors quadratically; ie, use the square root of the sum of the squares of the individual random uncertainties. 
Attachment 2

\section{Destructive Analysis Method Compendium}

Page 38 of 40

Table 2, Beginning and Ending Inventory Measurement Uncertainties

\begin{tabular}{|l|c|c|c|}
\hline Pu Form and Mass & Measurement & $\begin{array}{l}\text { Bias } \\
\text { (Systematic } \\
\text { uncertainty, } \mathbf{k g})\end{array}$ & $\begin{array}{l}\text { Precision } \\
\text { (Random } \\
\text { uncertainty, kg) }\end{array}$ \\
\hline $\begin{array}{l}1 \mathrm{Can} \text { of } \mathrm{PuO}_{2} \text { powder } \\
2 \mathrm{~kg} \mathrm{Pu}\end{array}$ & Weighing & 0.002 & 0.004 \\
\hline $\begin{array}{l}\text { Samples from above } \\
\text { can of powder }\end{array}$ & DA & TBD & TBD \\
\hline $\begin{array}{l}1 \text { tray of MOX pellets } \\
1.9 \mathrm{~kg} \mathrm{Pu}\end{array}$ & Weighing & 0.010 & 0.004 \\
\hline $\begin{array}{l}\text { Samples from above } \\
\text { MOX pellet tray }\end{array}$ & DA & TBD & TBD \\
\hline
\end{tabular}

Table 3. Monthly Throughput Measurement Uncertainties

\begin{tabular}{|l|c|l|l|}
\hline Pu Form and Mass & Measurement & $\begin{array}{l}\text { Bias } \\
\text { (Systematic } \\
\text { uncertainty, } \mathbf{k g})\end{array}$ & $\begin{array}{l}\text { Precision } \\
\text { (Random } \\
\text { uncertainty, kg) }\end{array}$ \\
\hline $\begin{array}{l}\mathrm{N} \text { cans } \mathrm{PuO}_{2} \text { powder } \\
2 \mathrm{~kg} \text { Pu each }\end{array}$ & Weighing & $\mathrm{N} \times 2 \times 0.001$ & Sqrt(N $\left.\times(2 \times 0.002)^{\wedge} 2\right)$ \\
\hline $\begin{array}{l}\text { Samples from above } \\
\text { cans of powder }\end{array}$ & DA & TBD & TBD \\
\hline $\begin{array}{l}15 \text { trays MOX pellets } \\
1.9 \mathrm{~kg} \text { each }\end{array}$ & Weighing & $\mathrm{N} \times 1.9 \times 0.005$ & Sqrt( $\left.\mathrm{N} \times(1.9 \times 0.002)^{\wedge} 2\right)$ \\
\hline $\begin{array}{l}\text { Samples from above } \\
\text { trays of pellets }\end{array}$ & DA & TBD & TBD \\
\hline $\begin{array}{l}\text { Scrap U/Pu powder } \\
5 \% \text { of total Pu (1 can) }\end{array}$ & NCC & $\mathrm{N} \times 2 \times 0.05 \times 0.05$ & $\mathrm{~N} \times 2 \times 0.05 \times 0.02$ \\
\hline
\end{tabular}

Step 9: Combine the uncertainties for the monthly throughput, and the beginning and ending inventories adding the systematic uncertainties directly and the random uncertainties quadratically. To satisfy the aim of being able to detect the theft of a "goal-quantity" of material, the overall uncertainty must be less than the goal-quantity. A conservative method for combining the systematic and random errors to obtain the overall uncertainty on the inventory is to add them together linearly. In this example, the resulting equation for the overall uncertainty has 5 unknowns - number of cans, bias and precision of both the DA of the powder and the DA of the pellets. To simplify we will combine the DA uncertainties of the powder and pellets and consider only the total DA precision and accuracy budget. 
Attachment 2

\section{Destructive Analysis Method Compendium}

Page 39 of 40

Step 10: One must now determine the target uncertainties for the DA method(s). Given that the equation for the overall uncertainty has three unknowns, it has a family of solutions. An easy way to study the effects of the various variables is to use a spreadsheet to model the behavior. If one fixes the number of cans and assumes the DA uncertainty is dominated by bias, one can set the precision uncertainty to zero and iteratively enter bias values until the calculated uncertainty equals the target value. One can then assume the DA uncertainty is dominated by precision and repeat the exercise. This sets the limits for the set of solutions. Intermediate cases can then be calculated. Finally, the number of cans can be changed and the calculations repeated. Results for several cases are presented in Figure 3. For a given number of cans, all points lying to the left of the line are combinations of bias and precision that will allow the DA goal to be met.

From Figure 3 one sees that both the precision and bias requirements for the DA analysis become less severe as the number of items (cans in this example) increases. The effect is greater for precision because the chance of the mean being offset by poor precision decreases as the number of measurements increases. (Another advantage of sampling and measuring more frequently is that it reduces the chance of theft from any single item going undetected.) The allowable bias is substantially less than the allowable precision uncertainty. Even for 50 cans the maximum allowable bias is only $0.5 \%$. If the bias is greater than this, it will be impossible to detect the diversion of a goal-quantity. This emphasizes the importance of recognized standards in determining bias.

If facilities employ gravimetric methods to assay their $\mathrm{Pu}$ and $\mathrm{U}$ oxides and metals. These methods, without impurity corrections, will be biased. If impurity corrections are made, the bias may be small. However, without standards bias estimates are subjective.

If facilities employ gravimetric methods to assay their $\mathrm{Pu}$ and $\mathrm{U}$ oxides and metals. These methods, without impurity corrections, will be biased. If impurity corrections are made, the bias may be small.

However, without standards bias estimates are subjective.

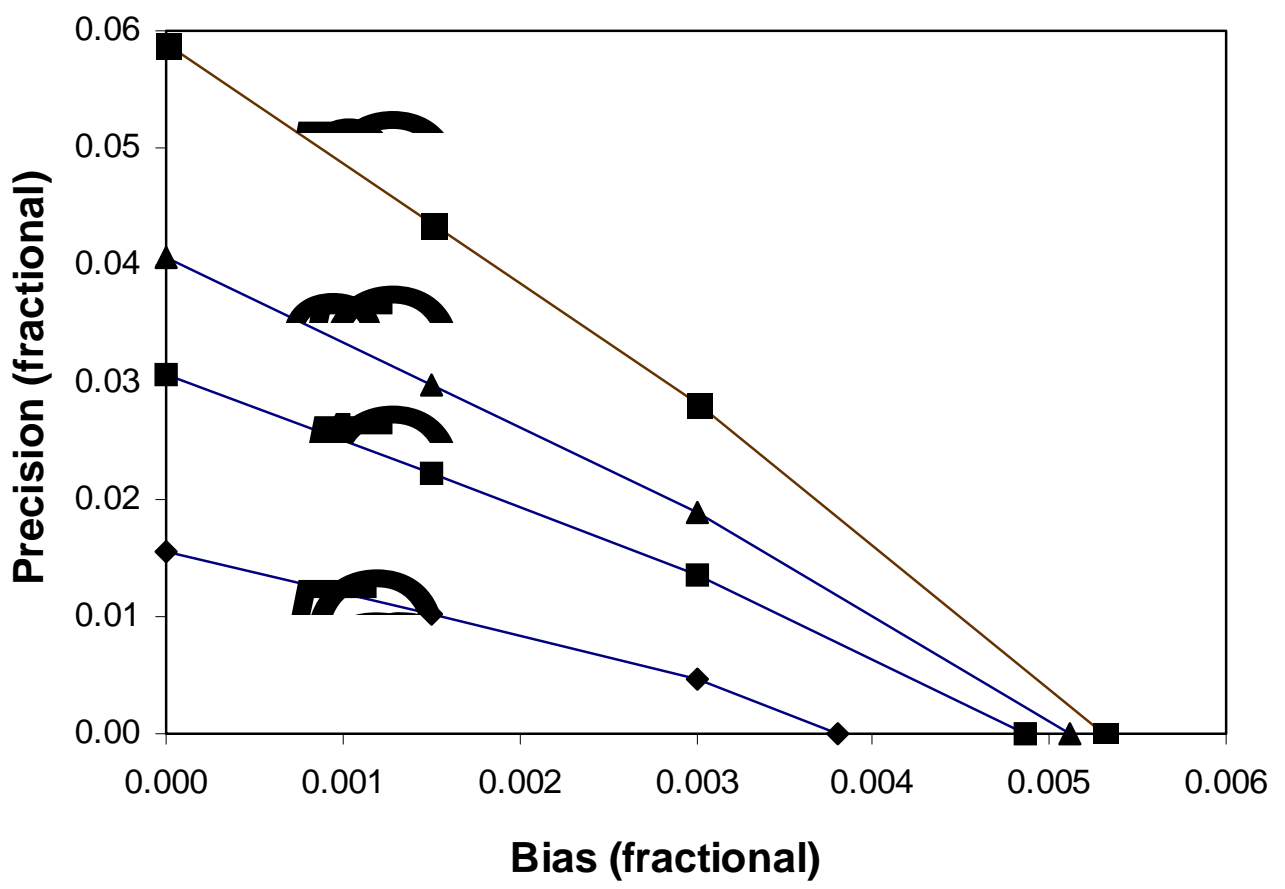




\section{Attachment 2 \\ Destructive Analysis Method Compendium Page 40 of 40}

\section{Figure 3}

The fact that the allowed precisions shown in Figure 3 are as high as $6 \%$ results from the particular example used. It was not selected to represent a challenging situation and should not be interpreted as implying that precision is generally of little concern. It does illustrate the importance of evaluating the specific situation before committing to upgrades. Evaluations of the need for measurement upgrades, DA or otherwise, should include similar calculations for the MBAs evaluated.

Conclusion: Systematic evaluation of the bias and precision at each measurement point, allows the determination of how "good" a particular measurement needs to be and whether theft-detection at the goal-quantity level can be achieved. Even using estimates of some of the uncertainties, a systematic approach is useful in determining which errors are dominant, how to "budget" the allowable errors, and how to invest wisely to improve accountancy. The 10 step process described and the suggested simplifications and approximations facilitate a simple calculation to make assessments of the adequacy of existing methods or to determine what upgrades would be required to allow the DA method to meet theft detection goal quantities. While the example given is hypothetical, it illustrates how one must carefully identify and estimate systematic uncertainties, which may sum to become the dominant source of the overall uncertainty. 


\section{Attachment 3}

\section{Memorandum SEO-MCA-2002-00032, “International Target Values as Goals for Facility Measurements Systems" \\ Page 1 of 6}

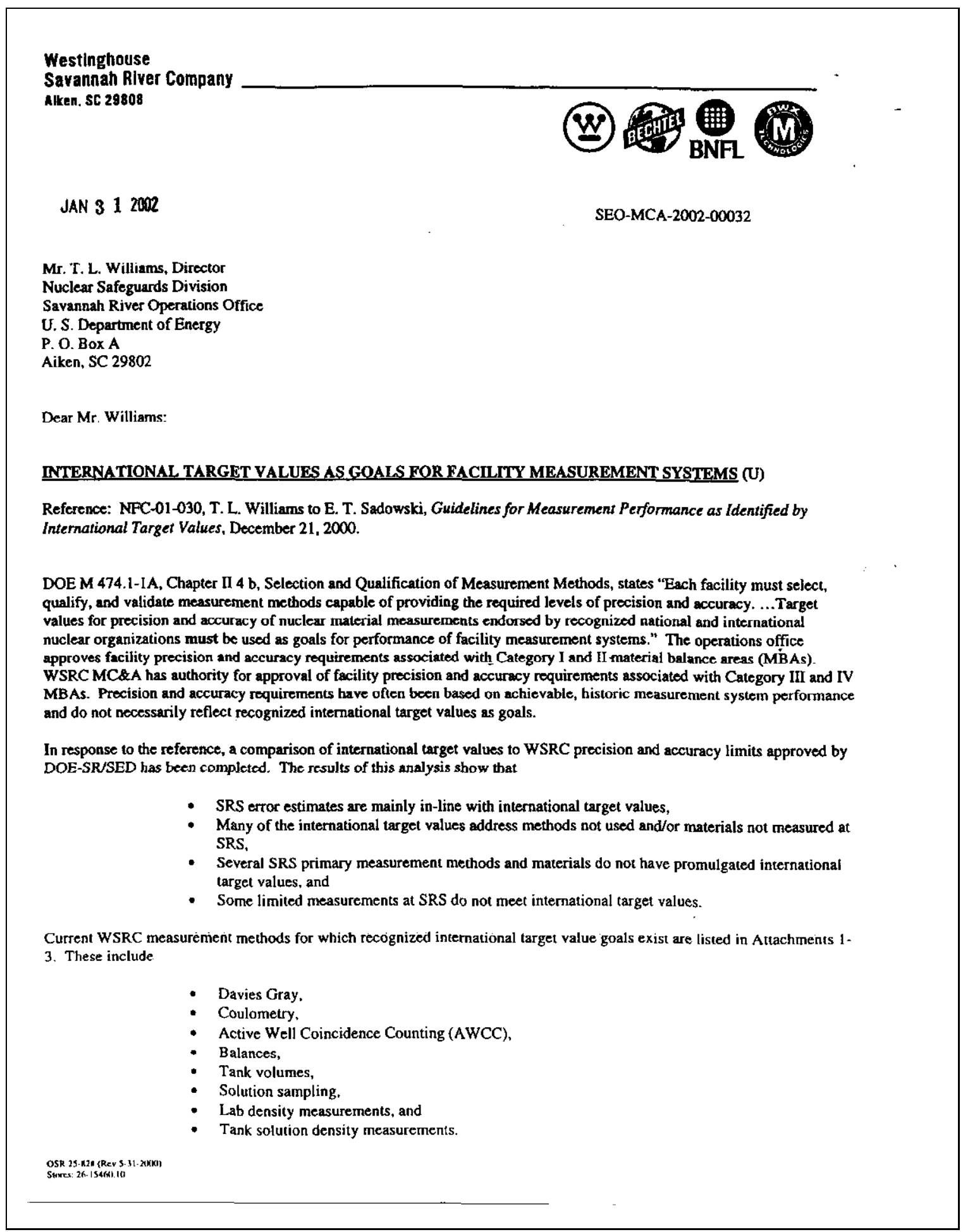




\section{Attachment 3}

\section{Memorandum SEO-MCA-2002-00032, “International Target Values as Goals for Facility Measurements Systems" \\ Page 2 of 6}

SEO-MCA-2001-00032

E. T. Sadowski

January 31, 2002

Page 2 of 6

Disconnects betwoen SRS measurement methods and materials and international target values include

- A primary NDA measurement method used at SRS for plutonium materials is calorimetry. There are no international target values for calorimeter performance,

- Plutonium metal material is a major itern measured at SRS. Plutonium metal is not a material addressed in international target values,

- The method used to measure input solutions for MBA FCA (F-Canyon) and MBA HBL (HB-Line Phase II) is diode array spectrophotometry (DAS) or Pu-TEVA (an alpha counting method). Neither of these methods is addressed by intemational target measurement values.

SRS methods are the same as those stated in the intemational target measurement document in the case of MBA HCA (HCanyon) input measurements. The target document also provides method for calculating or combining measurement errors. Comparisons between international target values and SRS values for HCA input measurements are given in Aftachment 4 and show SRS is aligned with these target values.

One example where SRS does not meet international target values is the IDMS method used for measuring Pu and U concentration for materials packaged out of the material characterization cabinet in FB-Line. The target values for both Pu and $U$ measurements of oxides using the IDMS methods show that SRS measurements are 4 to 10 times less accurate than the target values. (It should be noted that these methods have only been used for the last 1 to 2 years.) SS\&ES Commitment Tracking System Action 2002-0029 (due date 4/30/02) commits MPC\&A to (along with Analytical Laboratories Special Laboratories Section) identify improvements in/alternatives to the current HDMS methodology that will result in performance more closely matching the international target yalues for IDMS when measuring FB-Line Material Characterization oxides. The IDMS method as it is used for H-Canyon input measurements is in line with the equivalent internationaj target values.

Questions conceming this topic may be addressed to D. Malizia, 703-42A, 725-6824, Bpr. 15619.

Sincercly,

\section{E. T. Sxdoun $i$}

D. E. T. Sadowski, Manager

Materials Protection Control and Accountability

cc: J. T. Terrell, 703-42A

M. K. Holland, $704-3 \mathrm{~F}$

D. Malizia, 703-42A

F. G. Armstrong, 703-42A

D. J. Campbell, 703-42A

T. M. Barnett, 703-73A

G. T. Meyers, 703-42A

D. M. Smith, 703-42A

MC\&A Files, 703-42A 
Attachment 3

Memorandum SEO-MCA-2002-00032, “International Target Values as Goals for Facility Measurements Systems"

Page 3 of 6

SEO-MCA-2001-00032

E. T. Sadowski
January 31, 2002

Page 3 of 6

ATTACHMENT !

International Target Values at SRS

Bulk \& Density Measurements

\begin{tabular}{|c|c|c|c|c|c|c|}
\hline \multirow{2}{*}{$\begin{array}{l}\text { Measured } \\
\text { Material }\end{array}$} & \multirow{2}{*}{$\begin{array}{l}\text { Measured } \\
\text { Property }\end{array}$} & \multirow{2}{*}{$\begin{array}{c}\text { Measurement } \\
\text { Method }\end{array}$} & \multicolumn{2}{|c|}{$\begin{array}{l}\text { International } \\
\text { Tanget Values }\end{array}$} & \multicolumn{2}{|c|}{$\begin{array}{c}\text { SRS } \\
\text { Performance } \\
\end{array}$} \\
\hline & & & $\begin{array}{c}\text { Rondom } \\
\%,(1 s)\end{array}$ & $\begin{array}{c}\text { Systematic } \\
\%,(1 \mathrm{~s})\end{array}$ & $\begin{array}{c}\text { Random } \\
\%,(1 s)\end{array}$ & $\begin{array}{c}\text { Systemetic } \\
\%,(1 s)\end{array}$ \\
\hline Solutions & Volume & DIPT & 0.30 & 0.20 & 0.50 & 0.10 \\
\hline Solutions & Density & DIPT & 0.30 & 0.20 & 0.60 & 0.40 \\
\hline Solutions & Density & VTDM & 0.05 & 0.05 & 0.04 & 0.03 \\
\hline Any & Mass & EBAL & 0.05 & 0.05 & 0.02 & 0.02 \\
\hline Any & Mass & LCBS & 0.05 & 0.05 & 0.21 & 0.06 \\
\hline & & DIPT & Dip Tube & & & \\
\hline ' & & EBAL & Electronic B & & & \\
\hline & & LCBS & Load-Cell B & Weighing S & & \\
\hline & & VTDM & Vibrating $T$ & ensity Mete & & \\
\hline
\end{tabular}


Attachment 3

Memorandum SEO-MCA-2002-00032, “International Target Values as Goals for Facility Measurements Systems"

Page 4 of 6

SEO-MCA-2001-00032

January 31,2002

E. T. Sadowski

Page 4 of 6

ATTACHMENT 2

INTERNATIONAL TARGET VALUES AT SRS ANALYTICAL TECHNIOUES

\begin{tabular}{|c|c|c|c|c|c|c|c|}
\hline \multirow{2}{*}{$\begin{array}{c}\text { Measured } \\
\text { - } \quad \text { Material }\end{array}$} & \multirow{2}{*}{$\begin{array}{l}\text { Measured } \\
\text { Property }\end{array}$} & \multirow{2}{*}{$\begin{array}{l}\text { Measurement } \\
\text { Method }\end{array}$} & \multicolumn{2}{|c|}{$\begin{array}{l}\text { International } \\
\text { Target Values }\end{array}$} & \multicolumn{3}{|c|}{$\begin{array}{c}\text { SRS } \\
\text { Performance }\end{array}$} \\
\hline & & & $\begin{array}{c}\text { Random } \\
\%,(1 s)\end{array}$ & $\begin{array}{c}\text { Systematic } \\
\%,(1 s)\end{array}$ & $\begin{array}{l}\text { Rendom } \\
\text { qf, (1s) }\end{array}$ & $\begin{array}{c}\text { Syatematic } \\
\%,(1 s)\end{array}$ & $\begin{array}{l}\text { Btas } \\
\%, \text { (1s) }\end{array}$ \\
\hline $\mathrm{UO} 2\left(\mathrm{NO}_{3}\right)_{2}$ & $\mathrm{U}$ & $D / G$ & 0.1 & (nd) & 0.2 & 0.1 & \\
\hline $\mathrm{Pu}\left(\mathrm{NO}_{3}\right)_{4}$ & Pu & COUL & 0.15 & 0.15 & 0.11 & 0 & 0.13 \\
\hline Reprocessing solution & $\mathrm{U}$ & Sampling & 0.3 & 0.2 & 0.2 & (nd) & (nd) \\
\hline Other solutions & $\mathrm{U}$ & Sampling & 0.2 & (nd) & 0.2 & (nd) & (nd) \\
\hline $\begin{array}{l}\text { Reprocessing solution } \\
\text { Other solutions }\end{array}$ & $\begin{array}{l}\mathrm{Pu} \\
\mathrm{Pu}\end{array}$ & $\begin{array}{l}\text { DAS } \\
\text { Sampling }\end{array}$ & $\begin{array}{l}\mathrm{N} / \mathrm{A} \\
0.2\end{array}$ & $\begin{array}{l}\text { N/A } \\
\text { (nd) }\end{array}$ & $\begin{array}{c}1.18 \\
0.2\end{array}$ & $\begin{array}{l}1.08 \\
\text { (nd) }\end{array}$ & 0.27 \\
\hline U \& Pu compounds & Pu & IDMS & 0.15 & 0.1 & 0.565 & 0.987 & 0.65 \\
\hline & & & & & & & \\
\hline Solutions & Density & VTDM & 0.05 & 0.05 & 0.05 & 0.03 & \\
\hline \multirow[t]{9}{*}{ HEU } & $\mathrm{U}-235$ & TIMS & 0.05 & 0.05 & 0.04 & 0.06 & 0.05 \\
\hline & \multirow{2}{*}{\multicolumn{2}{|c|}{$\begin{array}{l}\text { (nd) } \\
\text { COUt }\end{array}$}} & \multicolumn{5}{|c|}{ International Target Values have yet to be defined } \\
\hline & & & \multicolumn{5}{|c|}{ Coulometry } \\
\hline & & $\begin{array}{l}\text { COUL } \\
\mathrm{D} / \mathrm{G}\end{array}$ & \multirow{2}{*}{\multicolumn{5}{|c|}{$\begin{array}{l}\text { Davies Gray } \\
\text { Diode Array Spectrometry }\end{array}$}} \\
\hline & & DAS & & & & & \\
\hline & & $\begin{array}{l}\text { IDMS } \\
\text { N/A }\end{array}$ & \multicolumn{5}{|c|}{ Isotope Dilution Mass Spectrometry } \\
\hline & & & \multicolumn{5}{|c|}{ Not Applicable } \\
\hline & & & \multicolumn{5}{|c|}{ Therthal Ionization Mass Spectrometry } \\
\hline & & & Vibrating Tut & ensity Meter & & & \\
\hline
\end{tabular}




\section{Attachment 3}

Memorandum SEO-MCA-2002-00032, “International Target Values as Goals for Facility

\section{Measurements Systems"}

Page 5 of 6

SEO-MCA-2001-00032

E. T. Sadowski
January 31,2002

Page 5 of 6

ATTACHMENT 3

International Target Values at SRS

NDA Measurement Techntques

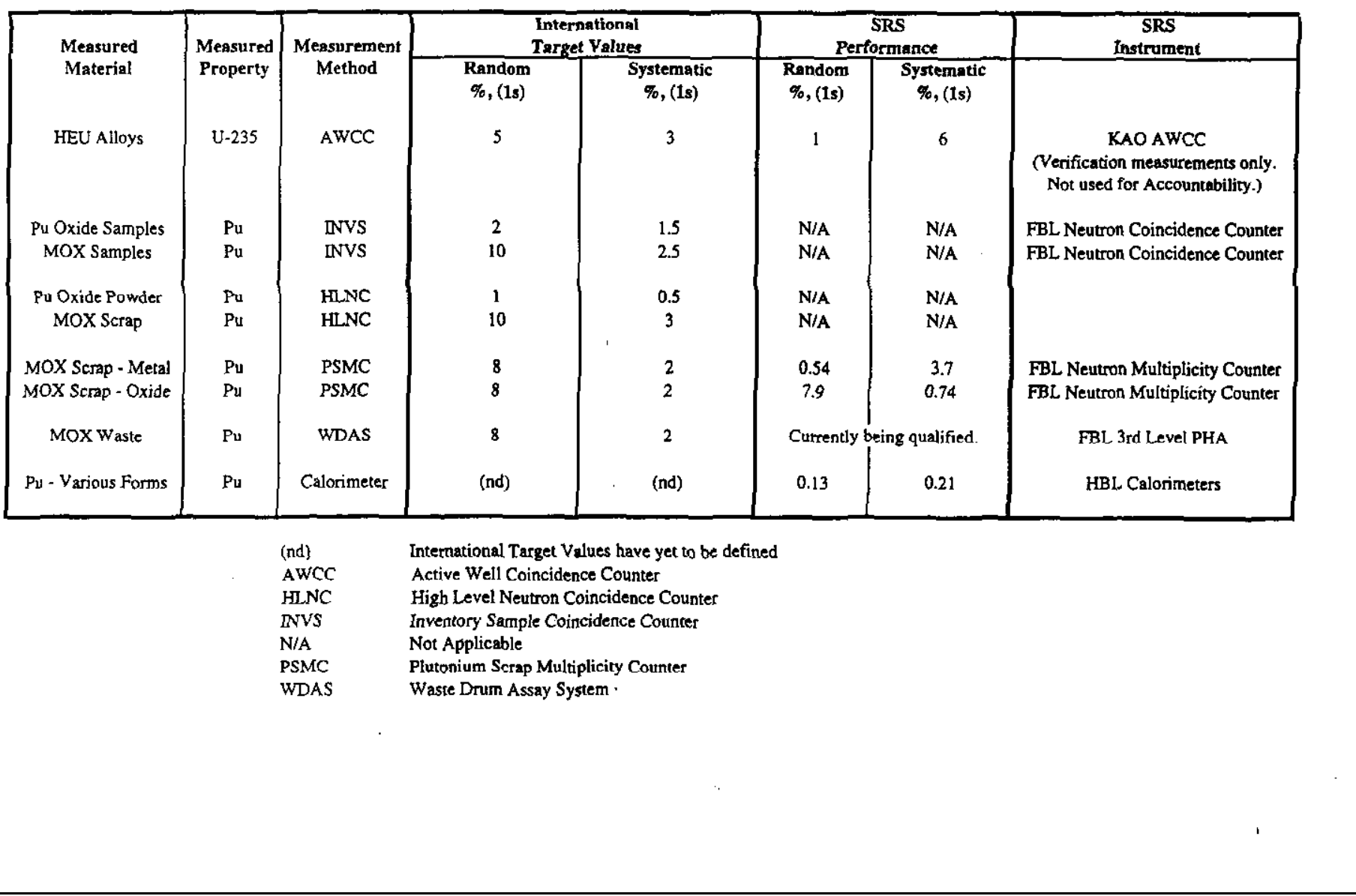


Attachment 3

Memorandum SEO-MCA-2002-00032, “International Target Values as Goals for Facility Measurements Systems"

Page 6 of 6

ATTACHMENT 4

International Target Values at SRS

Use of IITV:

is typical example of the use of ITVS at SRS is based on measurement of solutions entering the HCA In-Process subMBA.

\begin{tabular}{|c|c|c|c|c|c|c|c|c|c|}
\hline \multirow{3}{*}{ Megsurement } & \multirow{3}{*}{ Method/Instrument } & \multicolumn{4}{|c|}{ ITV } & \multicolumn{4}{|c|}{ H.Canzon } \\
\hline & & \multicolumn{2}{|c|}{ Random } & \multicolumn{2}{|c|}{ Systematic } & \multicolumn{2}{|c|}{ Random } & \multicolumn{2}{|c|}{ Systematic } \\
\hline & & \% rel. Std. Dev. & Variance & \% rel. Std. Dev. & Variance & $\%$ rel. Std. Dev. & Variance & \%o rel. Std. Dev. & Variance \\
\hline Volume & DIPT & 0.3 & 0.09 & 0.2 & 0.04 & 0.1 & 0.01 & 0.1 & 0.01 \\
\hline Sampling & Sampling & 0.3 & 0.09 & 0.2 & 0.04 & 0.2 & 0.04 & na & \\
\hline lement Concentration & DMS & 0.15 & 0.0225 & 0.1 & 0.01 & 0.53 & 0.2809 & 0.05 & 0.0025 \\
\hline sotope Concentration & TIMS & 0.05 & 0.0025 & 0.05 & 0.0025 & 0.1 & 0.01 & & \\
\hline Total & & & 0.205 & & 0.0925 & & 0.3409 & & 0.0125 \\
\hline Total Variance & & \multicolumn{4}{|c|}{0.2975} & \multicolumn{4}{|c|}{0.3534} \\
\hline $\begin{array}{c}5 \\
25\end{array}$ & . & \multicolumn{4}{|c|}{$\begin{array}{c}0.55 \\
1.09 \%\end{array}$} & \multicolumn{4}{|c|}{$\begin{array}{c}0.59 \\
1.19 \%\end{array}$} \\
\hline & DIPT & Dip Tute & & & & & & & \\
\hline & IDMS & Isotope Dilution $\mathrm{MB}$ & ss Speciron & & & & & & \\
\hline & TIMS & Themal Ionization & Mass Spectr & metry & & & & & \\
\hline
\end{tabular}




\section{Attachment 4}

\section{Memorandum TSD-CLS-2001-00070, “Application of the Runs Rule to Accountability Measurements in Central Laboratory Analytical Services" \\ Page 1 of 8}

\section{Westinghouse \\ Savannah Rlver Company}

Alken. \$C 29808

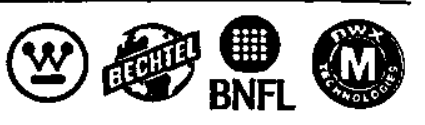

TSD-CLS-2001-00070

October 10, 2001

TO: $\quad$ Scott E. Federman, 772-F, CLAS Manager

FROM: Robin H. Young, 772-F

Michael K. Holland, 772-3F

Rify 6.: MKis

Application of the Runs Rule to Accountability Measurements in Central Laboratory Analytical Services (U)

This analysis concludes that Westinghouse Savannah River Company (WSRC) is not employing a valid statistical basis in its application of the Runs Rule to special nuclear material control and accountability. Department of Energy (DOE) orders do not require any use of a Runs Rule, but Central Laboratory Analytical Services (CLAS) believes that a statistically valid interpretation of the Runs Rule can be used for more effective measurement control, even with its highprecision instruments. CLAS plans to continue its present measurement control practices until critical changes in its Laboratory Information Management System (LIMS) can be implemented. In the interim, CLAS has issued procedural guidance to Cognizant Technical Functions (CTFs) directing them to periodically review accountability method control charts for adverse trends, including appropriate Runs Rule scenarios.

\section{Background}

In a recent audit finding (01May 17-SR-3804-SSPS-NMCA.2-008-C-O), DOE noted that CLAS was not complying with the Runs Rule requirement for accountability samples as described in WSRC Manual 14Q, Procedure 3.10. Specifically, DOE observed that CLAS CTFs did not investigate instrument performance when 8 consecutive measurements of the working standand fell on the same side of the centerline (known value).

CLAS has a rigorous measurement control program in place which tracks the performance of all measurement systems through the use of quality control synthetics (QCS). The performance for each method is tracked automatically by a Laboratory Information Management System (LIMS), which can be queried to determine if the measurement of a QCS exceeds the warning or alarm limits. The LIMS is not programmed to flag the occurrence of a Runs Rule violation.

All calibration and QCS solutions used for accountability measurements are prepared by mass from concentrated stock solutions. These stock solutions are characterized using the highest accuracy and precision analytical methods as well as primary reference standards. The calibration standards are utilized to calibrate the instruments while the QCS are employed to verify the method is in control.

Once a QCS solution is prepared, it is submitted by the QC organization for verification by the Operations lab staff. If the measurement of the QCS by the Operations lab is within two sigma of the known value (Case 1 LIMS classification), the standard is put into service. 


\section{Attachment 4}

\section{Memorandum TSD-CLS-2001-00070, “Application of the Runs Rule to Accountability Measurements in Central Laboratory Analytical Services"}

\section{Page 2 of 8}

TSD-CLS-200L-00070

Page 2 of 8

Key Principles

The application of the Runs Rule to accountability measurements at Savannah River Site should be based on sound quality control principles which consider the following points:

- the requirements in DOE Order M 474.1-1A

- the technical limitations associated with preparing, maintaining, and distributing standards in solution form

- the cost to implement and maintain a program for production of high-accuracy standards

- the accuracy and precision requirements (data quality objectives) of the Material Control and Accountability customers

Requirements from DOE Order M 474.1-1A

DOE Order M 474.1-1A defines the required components for the control and accountability of nuclear materials. In Chapter II, Section 4,e, Paragraph 8, DOE states "Control limits must be established at the two-sigma level (waming limits) and three-sigma level (alarm limits).

Control data exceeding the two-sigma levels must be investigated, and, when waranted, timely corrective action must be taken. If a single data point exceeds the three-sigma level, the measurement system in question must not be used for an accountability measurement until the measurement system is demonstrated to be within statistical control".

In view of the lack of a DOE requirement to use the Runs Rule, CLAS believes that WSRC is not using a graded approach in this area, particularly for analytical instruments with high precision. While the Runs Rule is a reasonable tool to observe instrument performance trends, it should not be applied when the technical basis for this control tool cannot be satisfied. The rule should be modified to address the technical basis issues.

Technical Limitations in Production of High-Accuracy Standards

To satisfy the technical basis for applying the Runs Rule, the total uncertainty associated with the individual vials of QC synthetics must be significantly better than the systematic and random uncertainties of the measurement method being controlled. At a minimum, the total uncertainty of the standard should be one-quarter (4-to-1) that of the method's short-term uncertainty if the current Runs Rule in $14 Q$ is to be satisfied.

To comply with the Runs Rule as a control for high-precision methods (coulometry, uranium Davies-Gray, mass spectrometry, density), a substantial improvement in the uncertainty of standards currently used in Central Laboratory Analytical Services would be necessary. At present, the uncertainty of the standards used for coulometry, uranium by Davies-Gray, mass spectrometry, and density are approximately equal to the uncertainty of the respective methods (1-to-1 rather than 4-to-1).

To illustrate, CLAS personnel reviewed the control charts for the methods used for accountability measurements. In the case of high-precision measurement systems (see attached charts for density and coulometry), the deviations of the 8 points comprising potential Runs Rule violations were within $0.2 \%$ of the known value. This magnitude of error is within the overall uncertainty of the standand and is not a clear indicator of measurement error as intended by the Runs Rule. In order to avoid a Runs Rule violation in these circumstances, the 
Attachment 4

\author{
Memorandum TSD-CLS-2001-00070, “Application of the Runs Rule to Accountability \\ Measurements in Central Laboratory Analytical Services" \\ Page 3 of 8
}

TSD-CLS-2001-00070

Page 3 of 8

uncertainty on the standard value would have to be so small that the preparation of the standard is not possible or is cost prohibitive. CLAS proposes that no action is necessary in this case.

The basis for the Runs Rule also has limitations when the short-term and long-term measurement precisions are significantly different. Uncertainty in the calibration standard can contribute to this effect and limit the ability of the Runs Rule to detect real measurement control problems. A hypothetical example illustrates the need for a graded approach to the Runs Rule. Suppose that a standard with a uncertainty of $0.3 \%$ is used in a method with a long-term precision one-sigma of $1 \%$. The warring limit for the method is then $+/-2 \%$ of the known value and the alarm limit is $+/-3 \%$. Further suppose that 8 consecutive points differ from the known value by +0.1 to $+0.5 \%$, which matches short-term instrument precision. The instrument would be treated as out of control using the current 14Q Runs Rule interpretation. and the working standard must be remeasured three times. For the CTF to place the unit back in service, all three remeasurements must fall within the two-sigma method uncertainty and one of the three must fall on the opposite side of the centerline. Again, CLAS proposes that no action is necessary in this case.

Now suppose the same hypothetical conditions apply but the deviation of the 8 consecutive points vary between +1.3 and $+1.7 \%$ of the known value. The bias exceeds the uncertainty of the standard and the precision one-sigma, which is clearly an undesirable trend. In this case, CLAS recommends that the CTF investigate the adverse trend, determine the root cause, and take corrective action, as warranted. Additional details on this follow-up are included below in the "CLAS Proposal for Runs Rule Violations" section.

\title{
Cost Limitations in Production of High-Accuracy Standards
}

The customer data quality objectives of CLAS accountability methods are at or near 4-to- $i$ versus the uncertainty of CLAS standards. However, CLAS does not have standards with uncertainties that are four times better than the optimum performance of its coulometry, DaviesGray titration, mass spectrometry, or density methods. In most cases, standards that would meet this criterion cannot be prepared. While the accuracy of each of these standards could be improved somewhat by changes in their preparation, storage, and characterization (which is dependent upon the uncertainty of the measurement method used for characterization), the cost of the accountability measurement program would grow considerably. Additional manpower and instrumentation would be necessary to handle standard preparation, which would likely become a full-time endeavor.

\section{Customer Data Quality Objectives}

In addition to historical reliability of the measurement method and the total uncertainty of the $Q C S$, the data quality objectives (accuracy and precision) of the customer musc enter into the proper application of the Runs Rule.

If a method with a supposed Runs Rule violation provides data that exceeds the accuracy/precision needs of the customer, the actual uncertainty may not be significant. As an example, CLAS normally provides accountability results for plutonium by one of three methods: Pu TEVA 3 Column - Alpha Spectrometry, Pu - Diode Array Spectrometry, and Pu -Coulometry. The method uncertainties for these three methods are approximately $8.5 \%$. $3.5 \%$, and $0.5 \%$, respectively. If a customer has traditionally received accountability measurements from a higher-uncertainty method, such as Pu TEVA, then results from a more 


\section{Attachment 4}

\section{Memorandum TSD-CLS-2001-00070, “Application of the Runs Rule to Accountability Measurements in Central Laboratory Analytical Services" Page 4 of 8}

\section{TSD-CLS-2001-00070}

Page 4 of 8

precise method, such as Pu - Coulometry, should be more than sufficient, even if the coulometry QCS show a Runs Rule violation that does not exceed the uncertainty on the QCS. The magnitude of the error on the coulometry is insignificant conpared to the $\mathrm{Pu}$ TEVA uncertainty.

\section{CLAS Proposal for Runs Rule Vlolations}

Trends falling outside both of the following Runs Rule criteria will be investigated.

1. Eight consecutive points on one side of the known value that exceed established uncertainties of the specific QCS and, if used, the calibration standards.

2. Eight consecutive points on one side of the known value that exceed 1-sigma of the method (see "Technical Basis for Limiting the Runs Rule to Eight Measurements Outside Method 1-sigma" below).

For any adverse Runs Rule trend, CLAS will document its investigation on a Control Chart Trending Problem Form, which will be copied to site Material Control and Accountability and the affected Material Balance Area custodians. Corrective actions required to return the measurement system to statistical control will be noted on the form. These corrective actions may entail re-calibration of the instrument, preparation of new standards and/or reagents, decontamination of the instriment, correction of calculation errors, or other actions deemed approptiate by the CTF. Before the system is returned to service, the working standard should be remeasured (recommended two or throe times) to demonstrate that the adverse trend has been resolved.

Technical Basis for Limiting the Runs Rule to Eight Measurements Outside Method 1-sigma The basis for limiting the Runs Rule to eight measurements outside of 1-sigma includes the following points:

- Short-term method precision and accuracy are often different than long-term method precision and accuracy. Significant degradation in short-term precision will be detected by alarm limits and warning limits. Less significant degradation will be detected as a significant trend indicator by CLAS"s implementation of the Runs Rule. However, short-tenm precision improvements and minor shifts in measurement bias will generate insignificant trend indicators within the long-term 1-sigma precision band.

- The measurement parameters and environmental sources that cause short-term improvements in random error and minor shifts in systematic errors are normally very difficult to detect and corrective actions are not always possible or appropriate. (For example, stable weather conditions have caused more stable laboratory temperatures, which may be the source of a significantly improved short-term precision during approximately the same period. This cause and effect may be correct, but corrective action is not appropriate).

- Interrupting analytical services for small errors ( -1 -sigma or less) is not practical or cost effective for either the customer or the laboratory when the likelihood of quickly identifying the source of the error is small and being able to implement effective corrections actions is even smaller. 


\section{Attachment 4}

\section{Memorandum TSD-CLS-2001-00070, “Application of the Runs Rule to Accountability Measurements in Central Laboratory Analytical Services"}

\section{Page 5 of 8}

TSD-CLS-2001-00070

Page 5 of 8

- Measurement errors in the range of I-sigma or less are typically of the same order of magnitude as sampling error, sample validation requirements, and the uncertainty in process tank volume measurements (these errors are root-mean-squared to produce total uncertainty).

- Under conditions where the random error is consistent with the long-term precision of the method and the data appear to be normally distributed, eight measurements will allow the method CTF to detect a significant systematic error provided it is greater than 0.84-standard deviations (Student's-t at 7 degrees of freedom/Sqrt(8); 2.37/2.83). Allowing conditions where the total uncertainty is on the order of 1-sigma, or less, is not a significant degradation in measurement control.

- It is appropriate to accept inherent systematic and random error in the range of 1 sigma, or less, from instrument calibration when it uses standard solutions that have to be processed through the entire measurement method to make them applicable/traceable. The number of calibration standards, the corresponding uncertainty, and the data quality objectives must be considered from both a technical basis and a practical/ogistic (cost effectiveness) basis when calibrating measurement systems.

\section{Conclusion}

Without modification, the Runs Rule as defined in WSRC 14Q is not an effective tool to apply as a control for CLAS accountability methods. CLAS has implemented a procedure (WSRC L21-001 18, "Accountability Method QC Chart Review", 10/09/01) that requires CTFs to periodically review accountability method control charts for adverse trends, including Runs Rule trends (where eight consecutive points exceed both the uncertainty of the standard and the 1-sigma uncertainty of the method).

CLAS plans to continue its present measurement control practices (system declared out-ofcontrol when one point falls outside the alarm limits or two consecutive points fall outside the waming limits) until critical changes in its LIMS can be implemented. CLAS will develop a schedule for implementation of an automated review and control system once it determines if the current LIMS can be reprogrammed or if a new LIMS system must be procured and configured. 
Attachment 4

Memorandum TSD-CLS-2001-00070, “Application of the Runs Rule to Accountability Measurements in Central Laboratory Analytical Services"

\section{Page 6 of 8}

.rSp-CS-2001.00070

Page 6 nf 8

DENSITY_CELL

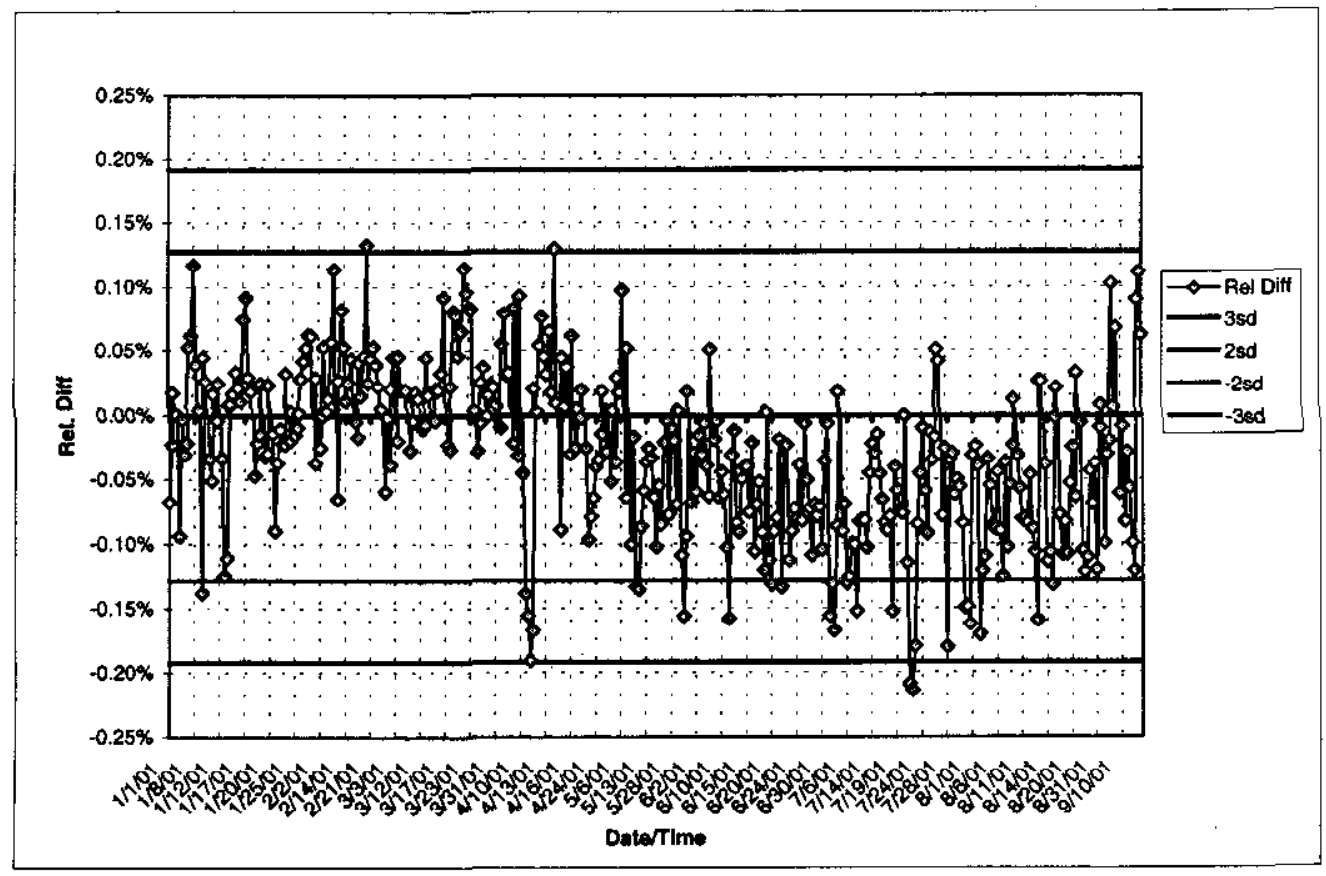


Attachment 4

Memorandum TSD-CLS-2001-00070, “Application of the Runs Rule to Accountability Measurements in Central Laboratory Analytical Services"

Page 7 of 8

TSD-CLS-2001-00070

Page' 7 or 8

PU_COULOMETAY

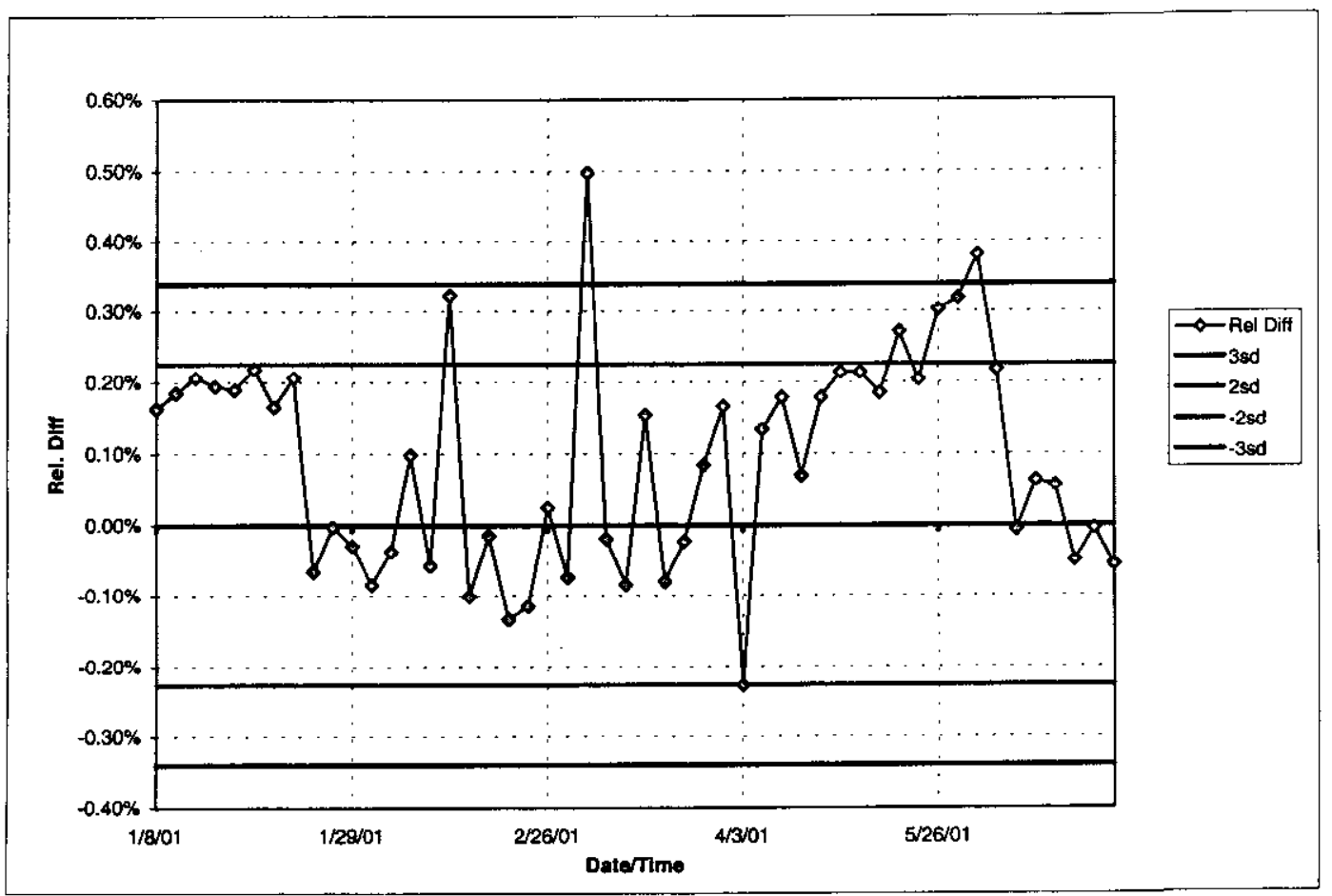


Attachment 4

Memorandum TSD-CLS-2001-00070, “Application of the Runs Rule to Accountability Measurements in Central Laboratory Analytical Services"

Page 8 of 8

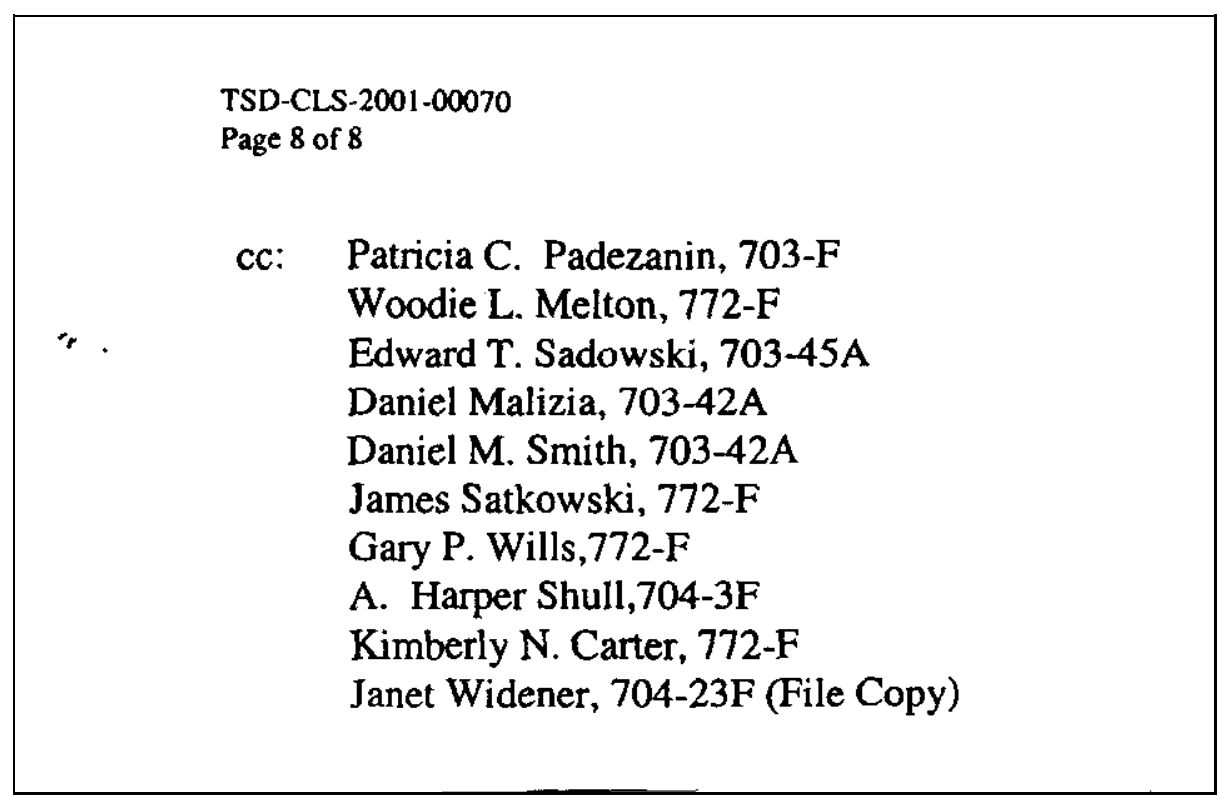

